SERIE HISTORIA / 1

EDICIÓN DIGITAL

\title{
Historia \\ social y política contemporánea
}

DOMINGO GARÍ

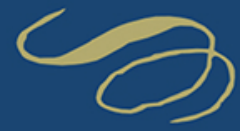

MATERIALES DIDÁCTICOS UNIVERSITARIOS

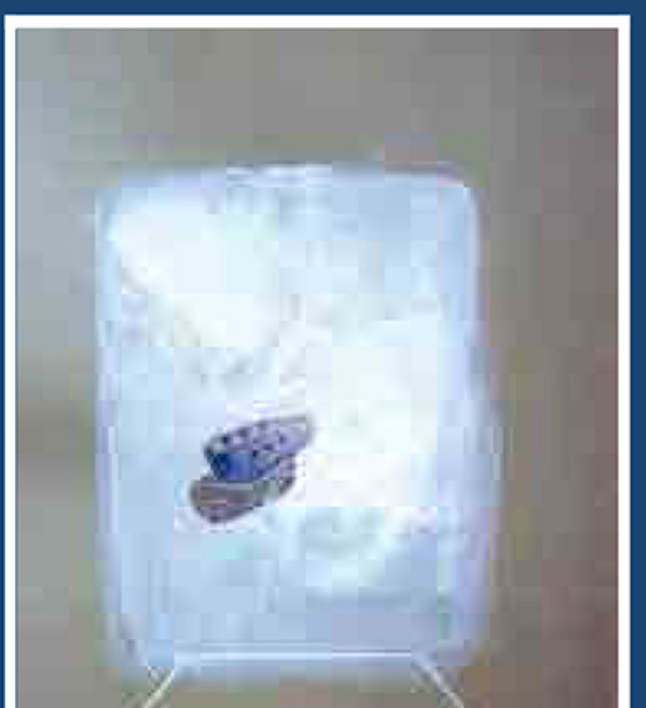




\section{Historia social y política contemporánea}



DOMINGO GARÍ

\section{Historia social y política contemporánea}


GARÍ HAYEK, Domingo (1962-)

Historia social y política contemporánea / Domingo Garí. —La Laguna: Servicio de Publicaciones, Universidad de La Laguna, 2017. —158 p.: il.; $22 \mathrm{~cm}$.

-(Materiales didácticos universitarios. Historia; 1) Anexos: Recomendaciones de películas y textos literarios. Mapas.

ISBN 978-84-15939-52-8

1. Historia contemporánea-S.18-20. 2. Historia contemporánea-Enseñanza.

I. Universidad de La Laguna. Servicio de Publicaciones, ed. II. Título III. Serie $94 " 17 / 20 "$

Colección:

MATERIALES DIDÁCTICOS UNIVERSITARIOS

\author{
Serie: \\ HISTORIA/1
}

Edita:

Servicio de Publicaciones

Universidad de LA LAGUNA

Campus Central

38200 La Laguna. Santa Cruz de Tenerife

Teléfono: +34 922319198

Diseño editorial:

Jaime H. Vera.

Javier Torres. Cristóbal Ruiz.

Motivo de cubierta:

Luis Carlos Espinosa.

Sin título: técnica mixta.

1. ${ }^{\text {a }}$ edición: 2017

Prohibida la reproducción total o parcial
de esta obra sin permiso del editor.

Maquetación y preimpresión:

Servicio de Publicaciones

Impresión:

Litografía Gráficas Sabater, S.L.

ISBN: 978-84-15939-52-8

Depósito Legal: TF 816/2017

DOI: https://doi.org/10.25145/b.2019.003 


\section{ÍNDICE}

1. INTRODUCCIÓN

1.1. LA FORMACIÓN DEL ESTADO-NACIÓN ………………………………………………………………... 12

1.2. NACIONALISMOS, REVOLUCIONES BURGUESAS Y MOVIMIENTO OBRERO …….............. 16

1.3. Revolución Rusa. El movimiento obrero SE CONVIERTe En Estado............... 20

1.4. Los FASCISMOS: EUROPA ABOCADA A LA GUERRA.................................................................... 26

2. RECONSTRUCCIÓN CAPITALISTA Y GUERRA FRÍA _................................ 31

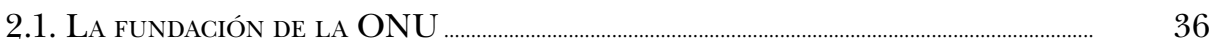

2.2. El nacimiento de la Europa unida bajo la hegemonía de EE. UU.............. 38

3. DESCOLONIZACIONES Y TERCER MUNDO …………………………………......... 43

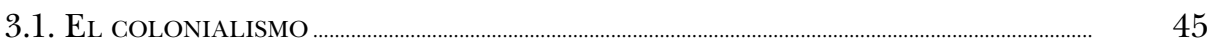

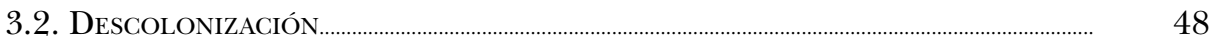

3.3. La cuestión de Oriente Medio ....................................................................................... 57

4. DINÁMICAS SOCIOPOLÍTICAS EN EL NORTE Y EL SUR: 1950-1980.. 61

4.1. LUCHAS DE LIBERACión NACIONAL Y GUERRAS CAMPESINAS EN CENTROAMÉRICA

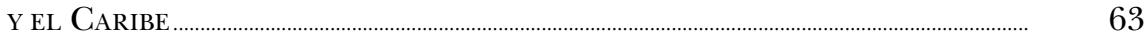

4.2. LOS NUEVOS MOVIMIENTOS SOCIALES: PACIFISMO, ECOLOGISMO, FEMINISMO ........... 70

5. EL FINAL DEL FASCISMO EN GRECIA, PORTUGAL Y ESPAÑA ….... 79

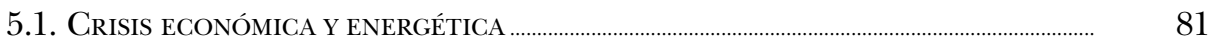

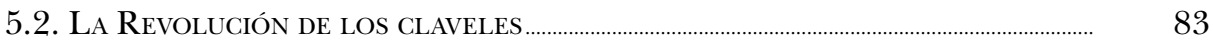

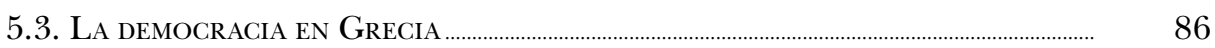

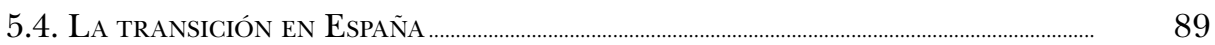

6. LAS DICTADURAS EN EL CONO SUR AMERICANO …............................. 95

6.1. La Operación Cóndor ......................................................................................................................... 97

6.2. Argentina: del peronismo a la Junta Militar …………………………………........ 98

6.3. Brasil: del Estado Novo a la democracia ……....................................................... 101

6.4. Chile: del gobierno de la Unidad Popular al golpe de Pinochet ............. 103 
7. LA URSS DESDE STALIN A SU BANCARROTA ………....................................... 107

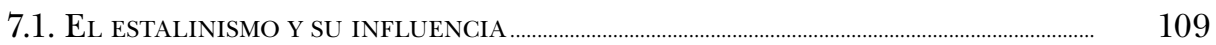

7.2. Del dinamismo con Kruschev al estancamiento con BrezneV........................ 111

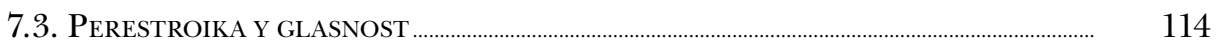

7.4. El FINAL DE LA URSS Y EL RETORNO DEL CAPITALISMO................................................... 118

8. LA CONTRARREVOLUCIÓN DE LOS OCHENTA ES INTERNA-

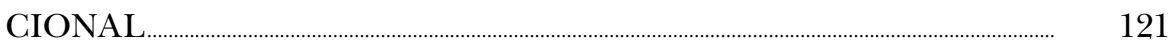

8.1. Neoconservadurismo en EE. UU. y Gran Bretaña ................................................... 125

8.2. RECONVERSIÓN INDUSTRIAL, PRIVATIZACIONES Y SINDICALISMO EN ESPAÑA......... 127

8.3. TRANSICIÓN CHINA AL NEOLIBERALISMO ............................................................................... 130

9. LOS MOVIMIENTOS SOCIALES ALTERGLOBALIZADORES .............. 135

9.1. LAS INSTITUCIONES NEOLIBERALES MUNDIALES................................................................. 137

9.2. El movimiento alterglobalizador: de Chiapas a Seattle .................................... 138

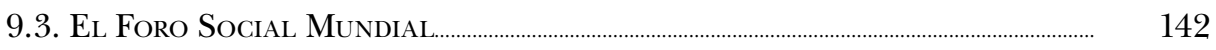

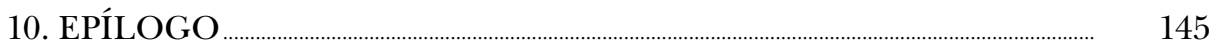

ANEXO I

RECOMENDACIONES DE PELÍCULAS Y TEXTOS LITERARIOS COMO MATERIAL COMPLEMENTARIO AL CONTENIDO DEL MANUAL

ANEXO II

MAPAS. 
1. INTRODUCCIÓN 

La historia es una disciplina que aborda los problemas del pasado y cómo estos han influido en el presente. Decía el historiador francés Pierre Vilar ${ }^{1}$ que la historia es una sociología del pasado. Esto quiere decir que los asuntos que planea investigar el historiador tratan los hitos fundamentales de una sociedad y un tiempo determinados. Esta sociedad y este tiempo pueden ser de corta o de larga duración, según nos enseñó Braudel². O pueden ser locales, regionales o globales e interconectarse, como ha estudiado Inmanuel Wallerstein ${ }^{3}$. La ciencia histórica trata de abordar los problemas seleccionados con ánimo de acercamiento a la verdad, aunque esta verdad es siempre revisable, y no puede ser formulada más que como un punto y seguido, en un proceso de investigación que viene del pasado y, por tanto, tiene su propia historia. El asunto de la objetividad solo puede ser planteado en plano de tentativa. Tendemos hacia ella, probablemente sin lograrla, pero no podemos dejar de hacerlo sin correr el riesgo de caer en una investigación cargada de subjetividad. Algunas filosofías de la historia buscaron la objetividad, pero el tiempo ha situado las aportaciones de todas ellas en un lugar más modesto. El positivismo, el idealismo, el marxismo, tras pretender que habían descubierto las leyes de la historia, y que por eso portaban un proyecto para el futuro, fueron situadas en lugares de menor envergadura, aun si se reconocen las aportaciones que todas han insuflado al conocimiento histórico. Por tanto, hoy decimos, no existe la verdad hacia el pasado ni hacia el presente, pero en el camino hacia su búsqueda vamos resolviendo los problemas que el pasado y el presente nos plantean como desafíos a nuestra sociedad.

El desarrollo del pensamiento posmoderno desde principios de los años setenta vino a reconocer este asunto. No - como se ha creído vulgarmenteechando por la borda al niño con el agua, como dice el refrán; no, por tanto,

${ }^{1}$ VILAR, Pierre, Iniciación al vocabulario del análisis histórico, Crítica, Barcelona, 1982.

2 Braudel, Fernand, La historia y las ciencias sociales, Alianza, Madrid, 1968.

${ }^{3}$ Wallerstein, Inmanuel, Geopolitics and geoculture. Essays on the changing world-system, Cambridge University Press, Cambridge, 1992. 
haciendo una defensa del relativismo extremo, en el sentido de que llegó el fin de la historia, tal cual escribió Fukuyama en los días finales de la guerra fría, y que por tanto todo saber histórico no es más que un relato construido sin fines prácticos y válidos para el conocimiento, como si la historia fuese indiferenciada del relato literario ${ }^{4}$. Obvio es reconocer que hay posmodernos que defendieron esa tesis. No son, ni fueron, todos. La posmodernidad vino a situar la investigación histórica en un parámetro más abordable para el propio historiador y, sobre todo, abrió el debate democrático dentro de la disciplina, despojándola de un dogmatismo extremo, que había perdurado durante demasiado tiempo y del que aún quedan defensores en la academia y fuera de ella.

Las dogmáticas de la historia siempre plantearon que esta había que verla en clave de evolución lineal, en la que la sociedad humana había tenido un recorrido desde la aparición de la especie hasta el final feliz que estaba por venir. Ese devenir fue leído en clave de democracia liberal por el pensamiento del establishment, de evidente influencia hegeliana; en clave de cielo para los creyentes de los diversos monoteísmos, de comunismo para Marx y Lenin o de la sociedad sin Estado para Bakunin y los anarquistas. La aberración suprema fue la lectura estalinista de Marx, que aplastó - en la consecución del comunismo a corto plazo en la URSS - la idea marxista de que la lucha final vendrá determinada por la desaparición de las clases sociales. El camino para Marx no era, sin embargo, el gulag ni el campo de exterminio en Kolimá o en la Siberia lejana, sino que tendría que venir de un proceso dialéctico y complejo sobre el que no habría fecha establecida, sino condiciones históricas determinadas.

Durante la posguerra mundial, cuando el pensamiento marxista era hegemónico en el terreno de la historia y de las ciencias sociales, los intelectuales del liberalismo afrontaron la necesidad de dar una batalla ideológica acerca de la historia, la economía, la política y la cultura. Friedman ${ }^{5}$, Von Hayek ${ }^{6}$ y Popper son destacados intelectuales de esa corriente. Para este último, la crítica al entonces todopoderoso marxismo vino desde el terreno epistemológico, toda vez que de lo que se trataba era de negar la validez científica de la historia, negando con ello la importancia objetiva que en ella tenían la clase obrera y las luchas de clases, según el corpus marxista. Popper sostiene que como la historia solo tiene un valor de enseñanza moral, y un sentido de indagación hacia los acontecimientos del pasado, no debe ser tomada como una totalidad, ya que para él esa idea «es un punto de vista que supone que la predicción histórica es el fin principal de ésta [...] y supone que este fin es alcanzable por medio del descubrimiento de

${ }^{4}$ Funuyama, Francis, El fin de la historia y el último hombre, Planeta, Barcelona, 1995.

${ }^{5}$ Friedman, Milton, Capitalismo y libertad: ensayos de política monetaria, Síntesis, Madrid, 2012.

${ }^{6}$ Von HaYek, Camino de servidumbre, Alianza, Madrid, 2005. 
los ritmos o de los modelos, de las leyes o de las tendencias que yacen bajo la evolución de la historia ${ }^{7}$. Popper desea refutar la tesis marxista de que existe un sujeto, el proletario industrial, y unas leyes históricas que irremediablemente nos conducen al comunismo, en tanto etapa superior del desarrollo económico, social y político.

Ese marco fuerte de crítica al historicismo marxista tuvo sus seguidores en las universidades españolas, en donde muchos de los historiadores de referencia mediática y académica se abonaron en parte a esta tesis de refutación de la historia con sentido de totalidad y sembraron la idea de que frente a ello la historia debería centrase en la búsqueda de razones y explicaciones parciales. No obstante, el debate, incluso dentro de la posmodernidad, tiene defensores del sentido emancipador que debe tener la historia. Vattimo, uno de los representantes más afamados del posmodernismo, sostiene que la filosofía de la historia no ha desaparecido, sino que se ha vuelto problemática, sin verdades absolutas, pero sigue constituyendo un hilo fuerte de nuestro pensamiento y de nuestra cultura. La concepción unitaria de la historia es un hilo rojo sobre el que poder proyectar el futuro, darle sentido, tomar decisiones. Este autor, considerado el filósofo de lo que se denominó el pensamiento débil, vuelve sobre la idea del comunismo en su libro Comunismo hermenéutico, editado en 2012, en el que expone que «el comunismo y la hermenéutica, en tanto que alternativas políticas al capitalismo neoliberal, se han convertido en respuestas alternativas para los perdedores de la historia, es decir, los débiles». Un comunismo que tiene necesariamente que ser pasado por la hermenéutica, por la crítica constante del texto. Un comunismo sin verdad absoluta.

También Josep Fontana ${ }^{8}$ defiende una historia con compromiso. Una investigación histórica que sea capaz de desvelar las legitimaciones en que se apoya la aceptación del presente y, sobre todo, que permita reconstruir una línea de progreso que pueda proyectarse hacia la clase de futuro que deseamos alcanzar. Piensa Fontana que el papel de la historia debe centrase en el análisis de las estructuras de poder y su enmascaramiento. Es decir, aunque ni siquiera tengamos claro qué futuro nos aguarda, la historia tiene el deber profesional de explicarnos cómo funcionan las redes de poder en una sociedad y un tiempo determinados. Quiere esto decir que la historia no debe solo describir los hechos, lo cual es importante, sino demostrar y explicar. Hay que responder a estas preguntas: cómo, cuándo, por qué.

Decía el maestro de historiadores Lucien Febvre que la historia es un combate, y que debe dotarse de todas las herramientas posibles que sirvan para su trabajo. Hay que ser multidisciplinar y hay que saber incorporar lo que

7 Popper, Karl, La miseria del historicismo, Alianza, Madrid, 2006.

${ }^{8}$ Fontana, Josep, La Historia después del fin de la historia, Crítica, Barcelona, 1992. 
cualquier campo del conocimiento nos puede aportar. «El historiador no va rondando al azar a través del pasado, como un trapero en busca de despojos, sino que parte con un proyecto preciso en la mente, un problema a resolver, una hipótesis de trabajo a verificar [...]. El hombre no se acuerda del pasado; siempre lo reconstruye. [...] No conserva en su memoria el pasado de la misma forma en que los hielos del Norte conservan congelados los mamuts milenarios. Arranca del presente y a través de él, siempre, conoce e interpreta el pasado» ${ }^{9}$. Interesa el pasado porque interesa el presente. Y sobre el pasado y el presente se entablan puntos de vista, controversias y posiciones políticas, económicas o de otro orden.

Teniendo en cuenta todo ello nos adentramos en la lectura de los hitos más importantes de la historia contemporánea y actual.

\subsection{LA FORMACIÓN DEL ESTADO-NACIÓN}

Suele ser consenso de la historiografía considerar la Revolución francesa como el momento fundante de los Estados-nación. La Revolución francesa comenzó siendo una revuelta de los privilegiados cuando estos solicitaron la convocatoria de los Estados Generales, en desacuerdo con las medidas fiscales introducidas por Calonne, el controlador general de Finanzas de Luis xvi, que implicaban que la aristocracia y el alto clero deberían, a partir de entonces, contribuir a la hacienda pública en función de la propiedad declarada.

Tal propuesta se había intentado poner en marcha unas décadas antes, sin éxito. Desde la década de 1730 la economía francesa estaba en periodo de crecimiento. La introducción de los avances tecnológicos de la revolución industrial tuvo consecuencias muy positivas a tales efectos. Se desarrollaron la agricultura, el comercio, la industria y el artesanado, y con ello la burguesía como un nuevo y potente actor sociopolítico. A finales de la década siguiente (1749) se propuso emitir un nuevo impuesto con el fin de reducir el déficit del Estado. Se pretendía un cobro de un $5 \%$ sobre las ganancias en todo tipo de actividad económica, tanto de la agricultura como de la industria o el comercio. Desde entonces los estamentos privilegiados se opusieron a dicha medida.

La última etapa del reinado de Luis xv estuvo marcada por la guerra de los Siete Años, la cual agrandó el déficit fiscal del Estado, tras la pérdida de las colonias americanas, lo que abocó al país a una crisis económica que terminó estallando en 1775. Los precios de los productos agrícolas se dispararon en los siguientes doce años, lo que motivó un renovado interés por volver a sugerir el establecimiento de impuestos a los miembros de todos los estamentos.

\footnotetext{
${ }^{9}$ Febvre, Lucien, Combates por la historia, Ariel, Barcelona, 1982 (1953), p. 32.
} 
La medida desató el desacuerdo de las clases nobles y llevó a la convocatoria de una asamblea general en la que también tenía representación el llamado Tercer Estado. Calonne, no obstante, tuvo que exiliarse en 1787 porque no obtuvo el favor del rey a sus propuestas y, en 1789, tras la convocatoria en Versalles de los Estados Generales, intentó regresar sin poder conseguirlo.

Cuando la asamblea entró en funcionamiento el 5 de mayo del año citado, al problema financiero, que aún permanecía irresuelto, se vinieron a sumar otras demandas solicitadas por los miembros del Tercer Estado recogidas en los «cuadernos de quejas», en los que se solicitaba la igualdad ante los impuestos y la ley, sirviendo por ello como base de la reivindicación central de la revolución que habría de acontecer.

Sin embargo, tal petición se encontró con el rechazo de los otros dos estamentos existentes en el momento de la convocatoria. El clero y la nobleza, que no compartían tal reivindicación, para ganar la votación bajo la representación estamental, bloquearon la posibilidad de que las votaciones se hicieran dando valor a los votos individuales y no a los estamentos, tal como solicitaba el Tercer Estado. Ante dicha negativa, los miembros del Tercer Estado decidieron reunirse por separado, bajo el nombre de Asamblea Nacional, en el frontón del juego de pelota, tras la orden real que decretaba el cierre de la Cámara.

Los miembros de la Asamblea Nacional comenzaron a ser presionados para que la disolviesen, pero, dispuestos a resistir, juraron no abandonarla hasta que se elaborase una nueva Constitución. Esto sucedió el día 20 de junio y quedó para la historia como el Juramento del Juego de Pelota. De esta manera la Asamblea Nacional se configuró como Asamblea Constituyente. Tras el intento real de suprimirla y liquidar así el desafío del Tercer Estado, el pueblo de París asaltó la fortaleza de la Bastilla el día 14 de julio, lo que dio inicio al periodo revolucionario. Rápidamente las revueltas prendieron por todo el reino.

Las medidas que tomó la Asamblea Constituyente fueron revolucionarias y significaron el comienzo de una nueva etapa histórica, con la cual se considera que empieza la Edad Contemporánea. Las principales medidas adoptadas fueron:

1. Abolición de los privilegios feudales y con ello final de la sociedad estamental.

2. Proclamación de los Derechos del Hombre y del Ciudadano, lo que trajo aparejada la soberanía nacional y la libertad e igualdad de los hombres. Todos estos principios se sancionaron formalmente en la Constitución de 1791, que tomó como precedente la Carta Magna norteamericana de 1787. En esta Constitución el sufragio tenía un carácter censitario.

3. Francia dejó de ser una monarquía absoluta y se configuró como una monarquía constitucional, en un primer momento moderada y dirigida por los girondinos (la derecha).

4. Redacción de la Constitución civil del clero, lo que suponía desgajar la Iglesia francesa de la obediencia al papa de Roma. 
La de Francia se erigió en modelo clásico de revolución burguesa, acabando con los privilegios estamentales e inaugurando la sociedad de clases y capitalista. Algunos antecedentes importantes de esta revolución social y política fueron las revoluciones políticas en Holanda (s. XVI), Inglaterra (s. XVII) y EE. UU. (s. XVIII) ${ }^{10}$.

La revolución impulsó en 1791 una Asamblea Legislativa, encargada de trabajar junto al rey en la elaboración de nuevas leyes. Pero el pacto de los sectores moderados de esta Asamblea con el monarca iba a tener cada vez más problemas para mantener la revolución dentro del marco de la monarquía parlamentaria censitaria. Desafíos de orden interno y externo terminarían por desatar la crisis de tal pacto. Tras la firma de la Constitución civil del clero, el rey intentó huir a Austria el 2 de junio de 1791. Fue descubierto en su huida y devuelto a París, lo cual puso en duda su lealtad al nuevo proceso iniciado, y de paso debilitó la posición de los sectores moderados que lo respaldaban en la Asamblea Nacional y a la misma Constitución monárquica. La detención del rey y su vuelta a París puso en guardia a las potencias absolutistas de Austria y Prusia, que decidieron intervenir para rescatarlo. La Asamblea Legislativa, dominada por los republicanos moderados (girondinos), se vio obligada a declarar la guerra a Austria en 1792, en contra del parecer de los sectores radicales de la revolución (jacobinos), quienes no estaban interesados en internacionalizarla porque los enemigos que rodeaban Francia eran muy poderosos y podrían echar al traste la propia revolución.

En el plano interior el frente revolucionario se escindió tras los primeros reveses militares en la primavera de 1792. De esta escisión nacieron los sans-culottes, quienes portaban propuestas más radicales, incorporando la reivindicación de cambios democráticos y sociales avanzados. Los sans-culottes emergían de las masas populares urbanas; sin embargo, aún «les faltaba espíritu de clase. Desperdigados en numerosos talleres, no especializados a causa del desarrollo restringido de la técnica, ni concentrados en grandes empresas o en barrios industriales [...], no eran capaces de concebir remedios eficaces para su miseria» ${ }^{11}$. Junto con los campesinos, de quienes no se diferenciaban mucho, expresaron el odio a la aristocracia, a los grandes y a los ricos, lo cual sirvió como el «fermento de la unidad de las masas trabajadoras ${ }^{12}$.

Estos revolucionarios instauraron en París, el 10 de agosto, una comuna revolucionaria que destituyó al rey y detuvo a sus seguidores. Acabó así la monarquía constitucional y se entró en la vía republicana. Una nueva Convención Nacional se puso en marcha en 1792, ampliándose con ella el derecho de sufragio,

10 Negri, Antonio, El poder constituyente. Ensayo sobre las alternativas de la modernidad, Libertarias / Prodhufi, Madrid, 1994.

11 Lefebvre, G., 1789. Revolución Francesa, LAIA, Barcelona, 1982, p. 293.

12 Ibíd. 
que ahora fue universal y masculino. La correlación de fuerzas en el seno de la Convención quedó reflejada de la siguiente manera:

1. Girondinos: su líder es Brissot. Son los representantes de la alta burguesía, partidarios de la vía moderada de la revolución, pueden ser considerados como republicanos de derechas.

2. Jacobinos: sus líderes son Robespierre y Saint Just. Es la burguesía media. Reciben el apoyo de los sans-culottes y de la Comuna de París. Evolucionaron hacia posiciones radicales. Son la izquierda.

3. Cordeliers: fracción a la izquierda de los jacobinos. Sus líderes son Hérbert, Danton y Marat. Junto con los jacobinos, forman el grupo de la Montaña en la Asamblea Nacional (izquierda radical).

4. La Llanura: en ella se situaba la mayor parte de los miembros de la Convención y fluctuaba entre los grupos anteriores (centro).

El periodo de la Convención tuvo dos etapas diferenciadas. La primera, liderada por los girondinos, se desarrolló entre septiembre de 1792 y junio de 1793. Logró el triunfo militar sobre los ejércitos prusianos en Valmy, pero finalmente tuvo que ceder a la presión de los jacobinos, y convino en la ejecución del rey en enero de 1793. Esto reactivó nuevamente la ofensiva de las monarquías europeas contra la revolución, en este caso bajo la dirección de la corona británica.

La segunda etapa de la Convención estuvo bajo el liderazgo de los jacobinos, que fueron sus jefes entre junio de 1793 y julio de 1794. En este periodo, en el que destacó la figura de Robespierre como líder indiscutido de la revolución, se convirtió el Comité de Salud Pública en órgano ejecutivo de la Convención ${ }^{13}$. Se creó un tribunal revolucionario y comenzó el periodo conocido como el Terror revolucionario (terrorismo de Estado). En esta etapa se redactaron una nueva Declaración de los Derechos del Hombre y del Ciudadano y una nueva Constitución de tipo más democrático, que aprobó el sufragio universal masculino.

Esta etapa revolucionaria de la Convención llegó a su fin en julio de 1794, tras un golpe de Estado llevado a cabo por los diputados de la Llanura con el que se depuso a Robespierre, que fue ejecutado. Dio así comienzo el periodo del Terror blanco o contrarrevolucionario. Esto aconteció en el mes de termidor, en el calendario revolucionario. De tal manera, esta palabra pasó a la historia con el significado de fin del proceso revolucionario, o al menos de la etapa de izquierda de tal proceso.

Tras el final de la dictadura revolucionaria se inició el periodo conocido como El Directorio, que duró desde 1795 hasta 1799. Después de la ejecución de los dirigentes revolucionarios, el proceso se recondujo por vías más modera-

${ }^{13}$ Bouloiseau, Marc, Robespierrre, Los Libros del Mirasol, Buenos Aires, 1961. 
das, que implicaron también un recorte de los derechos alcanzados en la etapa anterior. El poder ejecutivo lo detentaron cinco miembros, y el poder legislativo quedó constituido en dos Cámaras (Consejo y Senado). Tras este periodo de inestabilidades y disputas internas, Napoleón Bonaparte dio un golpe de Estado en noviembre de 1799, instaurando la dictadura y después el imperio.

El proceso descrito brevemente en las líneas precedentes abrió una nueva era histórica, que fue descrita por Albert Soboul de la siguiente manera: «La Revolución francesa emprendió la 'vía realmente revolucionaria' en el tránsito del feudalismo al capitalismo. Haciendo tabla rasa de todas las supervivencias feudales, liberando a los campesinos de los derechos señoriales y de los diezmos eclesiásticos, y en parte también de las obligaciones de la comunidad, destruyendo los monopolios corporativos y unificando el mercado nacional» ${ }^{14}$. Ello fue ejecutado políticamente por la dictadura jacobina, apoyada en las masas populares.

Con tal proceso se produjo la ruptura de las viejas estructuras del Estado absolutista y se abrieron paso las nuevas instituciones del Estado burgués: Parlamento, banco central, ejército de leva, aparato judicial, Ejecutivo. La Revolución francesa alumbró el camino del siglo xix y cambió el mundo desde entonces, junto con la Revolución americana contra el colonialismo británico. Con ambas revoluciones se fraguaron los Estados-nación contemporáneos.

\subsection{NACIONALISMOS, REVOLUCIONES BURGUESAS Y MOVIMIENTO OBRERO}

El siglo XIX apuntaló en toda Europa lo iniciado en Francia en 1789. De maneras diversas, una pactada y otra revolucionaria, se fueron formando los Estados-nación por todo el continente, aunque convivieron mucho tiempo, hasta la Primera Guerra Mundial, con las estructuras imperiales existentes, que, no obstante, fueron dando paso en todos los lugares a las nuevas formas de organización político-institucional. La base de los Estados liberales estaba echada. Por tanto, en un primer momento el nacionalismo y el liberalismo fueron de la mano ${ }^{15}$.

El ciclo de las revoluciones liberales comenzó hacia 1820 y afectó a Francia, Italia, Rusia, Grecia, España y Nápoles. Las constituciones liberales trataron de abrirse paso en un entorno poco amable, porque las monarquías del Antiguo Régimen eran poderosas y se habían unido en lo que se conoció como la Santa Alianza (1815), tras el final de las guerras napoleónicas ${ }^{16}$. El trienio liberal que se

14 Lefebvre..., p. 306.

${ }^{15}$ Hobsbawm, Eric, J., Los ecos de la Marsellesa, Crítica, Barcelona, 1992.

${ }^{16}$ RudÉ, George, Europa desde las guerras napoleónicas a la revolución de 1848, Cátedra, Madrid, 1982. 
vivió en España fue cerrado con una nueva vuelta al absolutismo en 1823. Desde el año anterior la guerra civil se había desatado entre realistas y liberales. "La proclamación de la constitución, en 1820, había tenido lugar sin ningún tipo de atropellos, de modo que no se puede hablar de violencia liberal hasta 1822 , cuando se inició en respuesta a la insurrección absolutista contra el régimen constitucional» ${ }^{17}$. El liberalismo corrió distinta suerte en esa década, pero animó las luchas de liberación nacional en el continente. La guerra de liberación griega se inició contra los turcos en 1821 y concluyó en 1829 con la derrota del Imperio otomano y la proclamación de la independencia en 1830. Los griegos estuvieron asistidos por los británicos y los rusos, ambas potencias interesadas en el debilitamiento del Imperio otomano.

Hacia 1830 la revolución volvió a Europa, esta vez con un carácter más extenso y profundo. Alcanzó nuevamente a Francia y se extendió a Bélgica y Polonia; en el caso de Alemania y de Italia adoptó la forma de construcción nacional que vendría a concluir en la década de 1870. En 1848, las revoluciones estuvieron protagonizadas por la burguesía liberal y los obreros industriales, que - aunque todavía en escaso número- ya comenzaban a emerger como una fuerza histórica para el futuro inmediato. Las revoluciones europeas de 1848 expandieron los ideales democráticos por todo el continente y fueron la consecuencia de una crisis bancaria en Francia, las malas cosechas y la extensión del paro. A esto se sumó el descontento por la falta de libertades y de derechos. Además de las «razones francesas» de la revolución, en cada lugar la chispa estalla en demanda de reivindicaciones específicas: en Italia, jaleada por el nacionalismo de Mazzini; en Austria y Prusia, las reivindicaciones democráticas se han regado como la pólvora; en Berlín, los obreros se enfrentan a los militares en demanda de un Parlamento democrático ${ }^{18}$.

Junto a la emergencia de las reivindicaciones democrático-liberales, hicieron irrupción las de naturaleza socialista, que, en cierta forma, venían a ser una extensión de las anteriores. El movimiento socialista irrumpió tras las revoluciones de 1848, dotándose con un armazón teórico de considerable bagaje. Desde la publicación del Manifiesto comunista en 1848, los pensadores del movimiento obrero fueron dotando de estudios teóricos, propuestas concretas y organización política a los proletarios urbanos.

En 1864 se creó en Londres la Asociación Internacional de Trabajadores, también conocida con el nombre de i Internacional Obrera. Fue integrada por sindicalistas, socialistas y anarquistas. Los estatutos fueron redactados por Carlos Marx. Bakunin, dirigente de la corriente anarquista, se incorporó en 1868, y a

${ }^{17}$ Fontana, Josep, De en medio del tiempo. La segunda restauración española, 1823-1834, Crítica, Barcelona, 2006, p. 87.

18 Aróstegui, Julio, La Europa de los nacionalismos (1848-1898), Anaya, Madrid, 1991. 
partir de entonces la AIT se fue fracturando en dos tendencias, que al poco tiempo llegaron a ser irreconciliables. Por un lado se significaron los anarquistas, con Bakunin como líder; por el otro lado, los socialistas, bajo el liderazgo de Marx.

En medio de las crecientes tensiones en el seno de la AIT se produjo la revolución comunera de París en 1871, tras la derrota de Napoleón iII en Sedán ante el Imperio prusiano. A raíz de dicha derrota desapareció el II Imperio francés, tras la abdicación del emperador, y se proclamó la Tercera República en Francia. Al comienzo de esta, la agitación política y social condujo hacia la insurrección que dio paso a la proclamación de la Comuna parisina. Este fue el primer gobierno obrero en la historia, y pasaría a la posteridad como el ejemplo clásico de asalto al poder por parte de los de abajo. La Comuna fue derrotada militarmente tras dos meses de gobierno autogestionado. Una masacre llevada a cabo por el ejército francés acabó con dicha experiencia revolucionaria. La derrota agrietó aún más las tensas relaciones dentro de la AIT y, tras el Congreso de La Haya de 1872, los anarquistas fueron expulsados de la organización, que quedó en manos de los socialistas marxistas hasta su disolución en 1876.

Las razones que llevaron a la ruptura del incipiente movimiento obrero habría que buscarlas en las siguientes desavenencias. En primer lugar, Marx y sus seguidores querían hacer de la AIT una organización estructurada en torno a un referente de autoridad, al objeto de favorecer la eficacia en la toma de decisiones. Por su parte, Bakunin y su gente se mostraban contrarios a cualquier tipo de autoridad o jerarquía en el seno de la AIT y abogaban por lo que denominaban el socialismo autogestionario.

En segundo lugar, los «marxistas» entendían que la revolución se llevaría a cabo por medio de una acción organizada, planificada y ejecutada por la clase obrera, fundamentalmente por los obreros de las industrias. Por su parte, los «bakuninistas» eran partidarios del individualismo y la espontaneidad, y opinaban que en la revolución los campesinos tendrían que jugar un papel relevante. Las influencias del anarquismo fueron de hecho muy grandes en países de estructura económica atrasada y de amplia base campesina, como Ucrania (Rusia) y España ${ }^{19}$.

En tercer lugar, los «marxistas» promueven la dictadura del proletariado como fase de transición hacia el comunismo, mientras que para los anarquistas ese concepto es un anatema, porque piensan que todo tipo de Estado, aunque sea obrero, se vuelve inmediatamente peligroso para los individuos y sus libertades.

En cuarto lugar, los «bakuninistas» son contrarios a que los obreros se organicen mediante partidos políticos y, en consecuencia, no deben intervenir en el Parlamento, en elecciones o en gobiernos de ninguna clase, ya que de esa manera perderían su fuerza revolucionaria. Para ellos la genuina organización

19 Termes, Josep, Anarquismo y sindicalismo en España: La primera Internacional (18641881), Planeta, Barcelona, 2000. 
obrera debe ser el sindicato. Por contra, los «marxistas» son partidarios de intervenir en política, por medio de la creación de partidos específicamente obreros, e incluso no son contrarios a colaborar con los partidos burgueses cuando estos apoyen las propuestas y las políticas de los partidos obreros.

Tras la frustrada experiencia de la i Internacional, se creó la segunda en 1889. Tuvo su sede en Bruselas y su orientación fue netamente socialista marxista. En ella no participaron los anarquistas, los cuales crearon sus propias organizaciones sindicales. La II Internacional la integraron los nacientes partidos socialistas de los distintos países europeos, adquiriendo una fisonomía de federación.

Entre los objetivos fundamentales de esta nueva organización obrera se encuentra la búsqueda de una legislación que se proponga mejorar las condiciones de vida de los trabajadores, con medidas tales como subsidios por desempleo, protección social y reducción de jornada laboral a las ocho horas diarias. La II Internacional creó también la simbología y las fechas identitarias del movimiento obrero, como la celebración del 1 de mayo (1889) como día internacional de los trabajadores, el 8 de marzo como día internacional de la mujer trabajadora (1910) o el himno de la Internacional.

Casi desde sus orígenes, la Internacional tuvo que confrontar dos tendencias centrales en su seno. Una denominada marxista, partidaria de la revolución insurreccional como modo de superación del capitalismo. Y otra de carácter reformista, que fue conocida con el calificativo de revisionista. Entre los representantes más destacados de esta tendencia encontramos a Eduard Bernstein. Su postulado, en oposición a los anteriores, estribaba en la búsqueda del socialismo por la vía parlamentaria y pacífica. Estas dos corrientes, a la postre, terminarían escindiéndose tras el inicio de la Primera Guerra Mundial y la revolución bolchevique, de la que surgió la tendencia comunista, que finalmente constituyó la III Internacional en 1919. La II Internacional se disolvió en 1916 por los desacuerdos en torno a la Guerra Mundial que había estallado en 1914. El patriotismo nacionalista se vio confrontado al internacionalismo proletario, y ello fue la causa principal de ruptura de esta experiencia internacionalista.

La III Internacional nació en un país que había hecho la revolución socialista. No era solo la expresión de organizaciones obreras federadas, sino que había un núcleo central en torno al Partido Comunista de la Unión Soviética, y un país recién creado, la URSS (Unión de Repúblicas Socialistas Soviéticas).

Esta Internacional se creó ante la pérdida de legitimidad de la segunda, cuando las posiciones mayoritarias dentro de esta decidieron apoyar a sus respectivos países en la guerra. Los obreros alemanes y franceses iban a dejar de ser fraternales y a entrar en combate para matarse unos a otros en los campos de batalla de la Primera Guerra Mundial. El internacionalismo se vino abajo y el nacionalismo y el militarismo mostraron su pujanza.

Cuando se fundó la III Internacional, el objetivo central era defender a la URSS de los ataques que recibía de las potencias mundiales. A la organización se suman los recién creados partidos comunistas, nacidos de la escisión de los parti- 
dos socialistas, e incluso, en un primer momento, se incorporan los anarquistas, aunque pronto se retiran y dejan de apoyar a la URSS, tras las persecuciones que sufrieron en Ucrania y en la propia Rusia desde el comienzo de la guerra civil entre rojos y blancos (1918-1921).

La organización Internacional, en línea con sus directrices, estableció que los partidos comunistas adscritos deberían organizarse al modo del PCUS y tener como primer y fundamental punto la defensa de la URSS, al entender que este era el primer Estado obrero del mundo, y en su defensa y fortalecimiento se encontraba la esperanza de que la revolución pudiese extenderse por Europa y el mundo. Paralelamente se plasmó la ruptura con los partidos socialdemócratas y se agrandaron las disputas hasta la lucha abierta entre las dos facciones.

Tras la muerte de Lenin y la entronización de Stalin como secretario general del PCUS y líder máximo de la URSS, la revolución giró desde su posición internacionalista y la defensa de la revolución mundial hacia la posición de defensa del socialismo en un solo país. La revolución y el comunismo fueron paulatinamente entrando en una vía de dictadura y de vaivenes en la política internacional. La III Internacional quedó disuelta en $1943^{20}$.

\subsection{Revolución RUSA. El movimiento obrero se convierte en Estado}

Si en 1789 la burguesía había tomado por asalto el poder, arrebatándoselo a la aristocracia y a la monarquía, en 1917 era el movimiento obrero el que hacía lo propio con el Estado zarista, el cual había comenzado una reforma democrática en marzo de dicho año, que no pudo llevar a término y que acabó desembocando en la revolución socialista de octubre de ese 1917. En términos de la significación histórica, los bolcheviques entendían su revolución como la continuación de la francesa. De esta manera, la Revolución rusa vendría a culminar el proceso iniciado en 1789, enarbolando las proclamas de libertad, igual y fraternidad. Los comunistas estimaban que, de aquella revolución, la fraternidad y la igualdad no se habían cumplido, y la libertad, que ellos denominaban burguesa, había quedado sometida a los dictados de los más fuertes. En su opinión la libertad estaba condicionada por el poder económico.

Los bolcheviques tuvieron que enfrentarse a una revolución en un país atrasado, y esto los obligó a repensar la teoría marxista en claves claramente revisionistas del pensamiento del propio Marx, para quien la revolución debería

${ }^{20}$ Droz, Jacques (dir.), Historia general del socialismo de 1875 a 1918, Destino, Barcelona, 1985. Kriegel, Annie, Historia de las internacionales obreras (1864-1943), Orbis, Barcelona, 1986. 
darse en los países más avanzados económica y tecnológicamente. Gramsci habló de que la revolución bolchevique se había realizado contra el capital.

Rusia era un país dependiente en términos del desarrollo capitalista. Se encontraba en la periferia del sistema económico y en este sentido era un país semicolonial. Aunque era un imperio, su fortaleza de antaño ya no era determinante en el siglo xx. Su industria y sus finanzas estaban en manos del capital extranjero, de los principales países de la Europa occidental. Esta situación subordinaba completamente la economía rusa y al Estado, que a la vez debía gravar con impuestos a los contribuyentes para soportar las deudas fiscales. Los que más pagaban eran los que menos tenían. El principal país acreedor era Francia, seguido de Gran Bretaña y Alemania.

Los sectores industriales y financieros, en los que se concentraba el desarrollo del capitalismo, estaban en las dos principales ciudades del Imperio: San Petersburgo y Moscú. Pero la inmensa mayoría de trabajadores eran campesinos, muchos de ellos pobres o en estado de semifeudalidad, a pesar de que la servidumbre se había liquidado formalmente en 1861. La burguesía era poco numerosa, y sus partidos políticos, débiles. Las clases medias y profesionales sumaban una franja minúscula de la población. La clase obrera, artífice de la revolución, estaba concentrada en las dos urbes industriales.

La monarquía zarista era autoritaria y teocrática, y el poder del zar no tenía contrapeso en ninguna institución. La policía política (Ojrana) cumplía una función muy importante, detectando y reprimiendo cualquier atisbo de oposición o crítica al zarismo. El mecanismo de la deportación a Siberia se usó profusamente para desactivar la protesta y a la oposición política.

La oposición al zarismo adquirió diversas fisonomías, comenzando por las revueltas en el campo, en las que el activismo anarquista y las organizaciones populistas jugaron un papel central. Los sectores de los intelectuales, denominados la Intelligentsia, también destacaron en esta lucha. Asimismo, los mencionados anarquistas y nihilistas, que abogaban por una revolución campesina, eran partidarios de educar al pueblo y, también, del uso de la violencia terrorista para conseguir sus objetivos. En 1881 mataron al zar Alejandro iI en un atentado.

También los narodnik o populistas fueron muy activos en la oposición al zarismo. Propugnaban una revolución de base campesina de inspiración socialista y abogaban por que el MIR (comunidad rural) se convirtiese en la base del proceso revolucionario. Partidarios de la colectivización de la tierra, negaban la necesidad de la etapa previa capitalista. Su fuerza fue decayendo hacia finales de la década de 1890. Tras la decadencia, el relevo lo tomó el Partido Socialista Revolucionario, conocido como los socialrevolucionarios o eseristas. Se fundó en 1901 y su líder más destacado se llamó Kerensky, quien posteriormente, entre febrero y octubre de 1917, dirigió el Gobierno provisional. Los eseristas proponían una sociedad colectivista de base rural, y en consecuencia recibían sus principales apoyos de los campesinos, aunque pequeños grupos de obreros industriales se sintieron identificados con este partido. 
El Partido Democrático Constitucional (Kadete) era de inspiración liberal y aspiraba a desarrollar la república parlamentaria de estilo europeo en Rusia. Se fundó en 1905 y su dirigente fue el historiador Pável Miliukov. La base de este partido era reducida en Rusia por las propias características de la sociedad: escaso desarrollo urbano, pequeña clase media.

El último gran partido político que operó como actor en la Rusia de principios de siglo xx fue el Partido Obrero Socialdemócrata Ruso, que había sido fundado en 1898. Era de inspiración marxista y sus dos primeros líderes fueron Plejanov y Martov. En su segundo congreso, celebrado en 1903, el partido se escindió en dos corrientes, que se denominaron menchevique (minoría) y bolchevique (mayoría). Las razones de tal escisión hay que buscarlas en los distintos enfoques que unos y otros defendían, de cara a cómo afrontar mejor la revolución socialista. Los mencheviques eran partidarios de hacer una revolución de los obreros y los campesinos, conjuntamente. Entendían que dicha revolución sería un periodo de transición que ayudaría a transformar a Rusia en un país industrializado, bajo un orden democrático-burgués (democrático parlamentario), y que esto era el paso previo para la posterior revolución hacia la sociedad socialista. Opinaban que la revolución debía ser un proceso escalonado en etapas. Tal teoría les hacía ser partidarios de llegar a acuerdos con los partidos «burgueses», al objeto de derrocar al zarismo e instaurar la república parlamentaria.

La otra escisión, los bolcheviques, cuyo dirigente era Lenin, abogaban por la toma del poder luchando simultáneamente contra el zarismo y los partidos burgueses. En disputa con los mencheviques, que en realidad eran más ortodoxos en la aplicación de las teorías de Marx, opinaban que Rusia no necesitaba pasar por la etapa de la democracia parlamentaria, sino que las masas obreras dirigidas por una minoría bien organizada podrían hacerse con el poder, por medio de una insurrección armada.

La Revolución rusa, que finalmente marcó todo el siglo xx, como veremos a lo largo de este libro, se produjo en tres actos principales y en una multitud de actos menores, de los que aquí no daremos detalles ${ }^{21}$. Los tres actos principales fueron la revolución de enero de 1905, la de febrero de 1917 y la de octubre del mismo año.

La revolución de enero de 1905 comenzó con una manifestación enorme de centenares de miles de personas: obreros, campesinos, mujeres, niños, dirigida por el pope (sacerdote ortodoxo) Gapón, del que se decía que era confidente de la policía y agente zarista, aunque lo cierto es que iba a la cabeza de dicha manifestación, que se dirigía al Palacio de Invierno del zar en San Petersburgo.

${ }^{21}$ CARr, Edward Hallett, La revolución bolchevique 1917-1923. 1. La conquista y organización del poder, Alianza, Madrid, 1979 (1950). HiLl, Christopher, La revolución rusa, Ariel, Barcelona, 1990. 
Las reivindicaciones que se llevaban consistían en unas peticiones que incluían mejoras salariales, jornada de ocho horas, libertad de sindicación y convocatoria de una asamblea constituyente.

Los manifestantes no fueron recibidos ni sus peticiones atendidas; en su lugar, la tropa abrió fuego y asesinó a más de mil de personas. Tal efeméride pasó a la historia con el nombre del «Domingo Sangriento». La población de la ciudad reaccionó con una oleada de protestas espontáneas, motines y la convocatoria de huelgas en las industrias. Las revueltas se extendieron también a Moscú, y producto de ellas se crearon los primeros sóviets (consejos). Las asambleas en los sóviets canalizaron la actividad política en las dos ciudades, y se fue extendiendo la protesta hacia más lugares del Imperio. Los marineros del acorazado Potemkin se sublevaron contra la oficialidad, mientras el buque estaba en el puerto de Odessa (Ucrania). El ejemplo cundió en otras unidades de marinos y en el ejército. Ante tal desborde, el zar se avino a reconocer parte de las peticiones de enero, aunque paralelamente intensificó la represión contra los dirigentes más destacados de los sóviets, quienes fueron encarcelados y posteriormente llevados a juicio y al destierro. Fue en ese contexto en el que sobresalió la figura de León Trotski ${ }^{22}$.

Tras esta revolución el país siguió dominado por el zar, pero su poder no era ya omnímodo ni divino a ojos de millones de campesinos y obreros, como lo era antes de 1905. Tras la Guerra Mundial y la crisis en que sumió al país la intervención de Rusia en ese conflicto, se activó de nuevo el proceso revolucionario en febrero de 1917, todavía con los contendientes en los campos de batalla de la Gran Guerra.

El segundo acto se vio acelerado por la crisis del ejército ruso en los campos de batalla. La tropa estaba mal alimentada, mal equipada, con pobre armamento y con oficiales muy mediocres. Los campesinos eran reclutados contra su voluntad y debían enfrentarse a los alemanes, que tenían un ejército muy superior tecnológicamente y estaban bien dirigidos y pertrechados. En tales condiciones las deserciones fueron masivas, y eran alentadas por los soldados y los militantes bolcheviques, que hacían llamamientos continuos a convertir la guerra mundial en guerra civil.

Ante tal situación, el zar no supo, o no quiso, tomar ninguna medida y siguió aplicando las mismas políticas de reclutamiento y mal gobierno. No quiso atender las demandas de los sectores reformistas del Parlamento para buscar una vía democrática de salida a la crisis, y quedó de esa forma bloqueada la opción reformista bajo la monarquía. El inmovilismo llevó a la revolución de febrero, que comenzó nuevamente en San Petersburgo, bajo la consigna de «pan y paz».

${ }^{22}$ Deutscher, Isaac, El profeta armado, Era, Chile, 2007. El profeta desterrado, Era, Chile, 2007. El profeta desarmado, Era, México, 1959. 
Tras las manifestaciones convocadas se paralizó la producción el día 23, extendiéndose desde entonces los motines y huelgas por todo el país, tal y como había ocurrido en 1905. Se enviaron tropas para contener las revueltas, pero los soldados simpatizaban con los manifestantes. Ellos eran también obreros o campesinos reclutados a la fuerza. El día 27 se constituyó el Gobierno provisional. El zar abdicó y se proclamó la república. El Gobierno provisional estaba apoyado por los liberales y socialistas moderados. Propusieron crear una república parlamentaria de «corte occidental», pero no se cumplió con la promesa de dejar la guerra y llevar a cabo una reforma agraria. El descontento de las masas seguía en alza y, además, los bolcheviques atizaban el fuego de la insurrección, mostrándose muy críticos con el Gobierno provisional y exigiendo que Rusia firmase la paz por separado con Alemania.

El creciente protagonismo de los sóviets produjo una dualidad de poderes. Por un lado se encontraba el Gobierno provisional, emanado de la revolución del mes de febrero, y por el otro, el Gobierno de los sóviets. Ambos emitían órdenes ejecutivas de manera independiente. En julio, tras unos meses de incertidumbre, se precipitaron los acontecimientos. Los bolcheviques crearon el Comité Militar Revolucionario y planificaron una insurrección armada contra el Gobierno provisional, que entonces dirigía Kerensky. El 25 de octubre se da la orden de asalto al Palacio de Invierno. En la noche del 24 al 25, los destacamentos armados del Comité Militar Revolucionario se apostaron en los lugares estratégicos de la ciudad, tales como la central de teléfonos, las estaciones de ferrocarriles y los edificios oficiales. Cuando el crucero de la armada (Aurora) lanzó los cañonazos contra el Palacio de Invierno, se dio la señal general de la insurrección. El asalto al palacio se saldó con la detención de todos los miembros del Gobierno provisional, salvo Kerensky, que logró huir y refugiarse en la embajada de los EE. UU.

Tras el asalto se constituyó el Consejo de Comisarios del Pueblo, presidido por Lenin. De esta forma la revolución socialista había comenzado. La toma del poder, que se hizo sin bajas mortales por ninguno de los bandos, se iba a encontrar en los años siguientes con una tenaz oposición que hundió a Rusia en una guerra civil de más de dos años.

Entre las primeras medidas que tomó el Gobierno revolucionario, emitidas en forma de decretos desde el día siguiente de la toma del poder, hay que destacar las siguientes:

1. Decreto sobre la tierra que supuso la nacionalización y reparto de los latifundios del Estado, la nobleza y el clero. Se abolió la gran propiedad sin indemnización, pero se respetó la propiedad de los pequeños agricultores.

2. Se firmó un armisticio con Alemania como paso previo al tratado de paz de Brest-Litovsk en marzo de 1918. Rusia perdía Polonia, Estonia, Letonia y Lituania, y se reconoció la independencia a Finlandia y Ucrania, pero a la vez ganaba la ansiada paz y la posibilidad de concretar los esfuerzos en la reconstrucción del país. 
3. Reconoció el derecho de autodeterminación de las nacionalidades que componían el Imperio ruso.

4. Tomó el control sobre las empresas y la banca, y abolió la propiedad privada sobre las mismas.

5. Convocó unas elecciones para formar la Asamblea Constituyente. En tanto, el Gobierno provisional, compuesto por los comisarios del Pueblo (ministros), se hizo cargo de la dirección del Estado.

En 1918 dio comienzo una guerra civil que concluyó en 1921. En ella se enfrentaron dos bandos. Los rusos blancos, formados por los restos del ejército zarista, los Cadetes, los eseristas y algunos mencheviques, quienes recibieron el apoyo de las potencias occidentales, sobre todo de Francia, EE. UU., Japón y Gran Bretaña. Del otro lado, el ejército rojo, de base eminentemente obrera y en menor medida campesina, que fue organizado y comandado por León Trotski. Los bolcheviques se impusieron tres años después, gracias a la descoordinación de las fuerzas blancas, la brillante dirección estratégica de la guerra impulsada por Trotski y el apoyo popular recibido de las masas de campesinos y obreros.

La guerra civil obligó a impulsar el denominado comunismo de guerra, en la práctica una dictadura férrea de los bolcheviques en el plano económico, político y social. Se estatalizaron todos los sectores económicos, se abandonó por completo el mercado y las pequeñas empresas capitalistas fueron eliminadas. Se inició un proceso de colectivización de la tierra, y además se requisaron granos y ganado a los campesinos, para abastecer a las tropas y a los obreros de las ciudades.

El comunismo de guerra sirvió para sentar de manera acelerada las bases del nuevo Estado, con un modelo que se fundamentaba en la centralización de las decisiones, que recayeron en manos de los altos órganos del partido y del Estado, al tiempo que comenzó un proceso de fusión, en la práctica, de esos órganos y se limitó la participación de otros grupos no bolcheviques en los lugares de mando. Este mecanismo de acción organizativa tuvo su reflejo en las políticas sobre las nacionalidades, las cuales quedaron supeditadas a la primacía de la República Socialista Federativa de Rusia, cuando quedó formalmente constituida la URSS (Unión de Repúblicas Socialistas Soviéticas) en 1922.

El periodo del comunismo de guerra llevó al país a una situación de colapso económico, acentuado por el boicot que sufría por parte de las potencias, y por ello en 1921 se produjo un cambio de rumbo en la dirección de los asuntos económicos y se puso en marcha el plan denominado Nueva Política Económica (NEP), que pasaba por permitir la entrada de actividades capitalistas en la pequeña escala, a fin de estimular la producción. La NEP trajo buenos resultados y consiguió una mejora sustancial de la producción agrícola, elevando con ello los índices de vida de la población, lo que redundó en la mejora de las infraestructuras y la industria. Pero la NEP volvió a generar una nueva burguesía nacida bajo el paraguas de esas actividades y provocó tensiones sociales y políticas que desembocaron en el nacimiento de la dictadura estalinista. 
La URSS se constituyó formalmente en 1922 y la integraron las repúblicas de Rusia, Ucrania, Bielorrusia, Transcaucasia, Georgia, Azerbayán y Armenia. La capital era Moscú. En 1924 se adhirieron tres nuevas repúblicas caucásicas, Uzbequistán, Turkmenistán y Kirguistán, y en 1929 se sumó Tayiquistán. La URSS era un Estado plurinacional y multiétnico que ocupaba en extensión las tierras que habían conformado el Imperio zarista. Fue gobernada durante toda su existencia, hasta su desaparición en 1991, por un sistema de partido único, el Partido Comunista de la Unión Soviética (PCUS). En 1923 se elaboró una Constitución que delimitaba las funciones del nuevo Estado en materia de planificación económica y asuntos militares y señalaba el papel de las repúblicas en el seno de la Unión, a las que formalmente se les reconocía el derecho de autodeterminación. A la institución que emulaba los parlamentos de las repúblicas occidentales se le denominó Sóviet Supremo. Este órgano legislativo era el encargado de elegir a los componentes del Presidium, que era una jefatura de Estado colectiva. El presidente era el jefe del Estado. Además, elegía a los comisarios del Pueblo (ministros). La URSS comenzó a ser reconocida internacionalmente en 1924, lo que le supuso normalizar las relaciones con muchos países.

También en 1924 murió Lenin, hasta entonces el líder indiscutido del partido y del Estado. Tras su desaparición se abrió un periodo de luchas por el poder, en las que distintas facciones del partido se disputaron su control. Las figuras más relevantes del bolchevismo de la primera hora fueron trenzando alianzas diversas en esa lucha por el poder. A lo largo de la década de los veinte, Stalin, desde su puesto de secretario general del partido, logra hacerse con todo el poder, desplazando a sus adversarios. Hacia 1929, con la expulsión definitiva de Trotski del partido y del país, se consumó la dictadura estalinista, que muchos comparan con el llamado periodo de termidor de la Revolución francesa. Es decir, la dictadura estalinista es el termidor soviético, y, con la entronización del líder, la revolución entra en una nueva etapa, marcada por el dominio de la reacción (contrarrevolución) en su seno ${ }^{23}$.

\subsection{LOS FASCISMOS: EUROPA ABOCADA A LA GUERRA}

Los movimientos fascistas surgidos en Europa nacieron, en parte, motivados por la crisis tras la Primera Guerra Mundial, la crisis financiera de 1929 y el auge de los movimientos de inspiración comunista, después del triunfo de estos en la antigua Rusia zarista. Los años veinte fueron efímeramente optimistas (en muy pocos lugares), en especial en los EE.UU., pero a finales de la década la

${ }^{23}$ CARr, Edward Hallett, La revolución rusa: de Lenin a Stalin, 1917-1929, Alianza, Madrid, 2002. 
crisis financiera azotó los pilares de la economía capitalista mundial, sumiendo a los países más avanzados en el paro masivo y la ruina de amplios sectores de la sociedad. En donde apareció con fuerza por primera vez el fascismo fue en Italia, aunque desde el principio de la década de los veinte estaba presente en Alemania.

Los fascios eran organizaciones armadas que se crearon en 1919 con el objetivo de funcionar como rompehuelgas. Promovían la violencia callejera a fin de crear malestar social y así lograr el rechazo de las clases medias contra el movimiento obrero. Su misión consistió en enfrentarse a los anarquistas, socialistas y comunistas durante el bienio rojo que azotó el norte de Italia entre 1919 y 1920, y especialmente la ciudad de Turín. Las ocupaciones de fábricas en todo el norte, dirigidas por los Consejos de Fábrica, traían a Italia el eco de los sóviets de los días previos a la Revolución rusa de 1917.

Los fascistas entraron en el Parlamento italiano bajo el paraguas de las siglas del Partido Liberal y se hicieron notorios en agosto de 1922, cuando lograron mantener los servicios públicos durante la huelga general de agosto. Seguidamente los fascistas organizaron la marcha sobre Roma, desfilando con milicias marciales. Concluida esa demostración de fuerza, el rey Víctor Manuel encarga a Benito Mussolini la formación de gobierno.

El fascismo inicia una ofensiva en el plano político y sindical. Suprime las organizaciones obreras y crea el Gran Consejo Fascista. En el plano económico impulsa el corporativismo y las grandes empresas estatales en régimen de monopolio. Estas medidas fueron copiadas posteriormente en España por la dictadura de Primo de Rivera (1923-1930), quien había llegado al poder por medio de un golpe de Estado, de acuerdo con el monarca Alfonso xiII.

El nazismo comenzó a fraguarse desde 1923, año en que el Partido Nacionalsocialista Obrero Alemán celebra su primer congreso. Se estima que entonces lo formaban en torno a 20.000 militantes. En ese mismo año los franceses y los belgas ocupan la región alemana del Ruhr, reclamando los pagos de guerra que Alemania había dejado de cumplir. Tales pagos se le impusieron al ser derrotada en la Primera Guerra Mundial.

Los nazis organizaron protestas contra estas ocupaciones y llevaron adelante sabotajes contra los ocupantes. El Estado alemán se comprometió a indemnizar a los afectados por la acción de las tropas franco-belgas, para lo que emitió abundante deuda en papel moneda, medida que trajo aparejada una hiperinflación que terminó de hundir la economía alemana. Amplias masas de las clases medias y de trabajadores fueron empobrecidas y las tensiones sociales se dispararon. Los socialistas y los comunistas eran fuerzas muy importantes, y el movimiento obrero estaba entonces de su parte. Incluso en 1923 hubo preparativos para llevar adelante una revolución socialista en Alemania, que finalmente no se ejecutó. Los comunistas alemanes lo habían intentado también en 1919, con idéntico resultado. A pesar de la crisis, el Estado alemán era muy fuerte para poder ser derrotado por una insurrección como la ocurrida en San Petersburgo en 1917. 
En 1923 los nazis intentaron dar un golpe de Estado organizando el putsch de Múnich, para llevar al Gobierno al general Ludendorff y terminar con la República de Weimar. La manifestación convocada por el Partido Nazi logró reunir a muchos miles de partidarios, pero las fuerzas de policía la reprimieron, acabando de esa forma con el intento de golpe. La idea de Hitler era, una vez tomado Múnich, avanzar hacia Berlín, emulando la marcha sobre Roma de Mussolini del año precedente.

Hitler fue detenido, juzgado y condenado a cinco años de cárcel. Durante su reclusión escribó su libro Mein Kampf (Mi lucha), publicado en 1925. En el libro expresaba con toda claridad cuáles eran sus postulados ideológicos. Se asentaban sobre tres pilares básicos: antisemitismo, anticomunismo y antiliberalismo. El libro, una vez que los nazis tomaron el poder, se convirtió en texto de obligada lectura en los colegios, y sus principios fueron repetidos y divulgados por los medios de difusión masiva de manera permanente.

En mayo de 1928, tras las elecciones parlamentarias, los nazis obtuvieron 12 asientos en el Reichstag (2\%), mientras que la izquierda obtenía un claro triunfo. El Partido Socialdemócrata Alemán (SPD) ganó los comicios, con el $29 \%$ de los sufragios y 153 escaños. Los comunistas del KDP obtuvieron el $10 \%$ de los votos y 54 escaños. El Partido Nacional del Pueblo de Alemania obtuvo 73 escaños. El partido del Centro, 61. Otra serie de partidos menores se repartieron el resto de escaños, hasta completar los 491 que en aquel entonces componían el Parlamento de Alemania.

Dos años después (1930), y tras el crack financiero de 1929, en unas nuevas elecciones parlamentarias los nazis obtienen 107 diputados. Habían logrado pasar de 810.127 votos a más de 6,5 millones, alcanzando el $18 \%$ del sufragio. Los comunistas experimentaban un alza de más de un millón de votos, pero se quedaban con 4,5 millones y 77 diputados. No obstante, el partido vencedor volvía a ser el SPD, con cerca de ocho millones y medio de votos $(24,53 \%)$ y 143 diputados. A pesar de ello, la fuerte emergencia de los nazis había situado a Alemania en una situación peligrosa y extrema.

En la siguiente convocatoria electoral anticipada, señalada para julio de 1932 y motivada por la inestabilidad política y el ahondamiento de la crisis económica y social, los nazis obtuvieron una sonora victoria con 230 diputados, alcanzaron la mayoría minoritaria en el Parlamento y desplazaron como primera fuerza al SPD, que con el 21,58\% de los votos y 133 escaños se vio relegado a la segunda posición. Los comunistas, con el 14,30\% y 89 diputados, alcanzan el tercer lugar. Siguen una serie de partidos que se reparten los escaños que restan hasta alcanzar los 608. En la posterior convocatoria, de noviembre de 1932, los nazis alcanzaron 166 diputados: perdieron 34 asientos, pero quedaron nuevamente por encima del SPD, que logró 121. Tras estas elecciones Hitler es nombrado canciller. Las siguientes elecciones, convocadas ya por los nazis, le dieron un amplio triunfo, con 288 diputados, pero sin mayoría absoluta. Estas elecciones se desarrollaron en un clima de violencia fascista y no son consideradas como democráticas. Los 
nazis habían quemado el Reichstag en febrero y culpabilizaron a los comunistas. En noviembre de 1933, Hitler convocó nuevamente elecciones, pero esta vez con todos los partidos prohibidos. Obtuvo la mayoría absoluta, dado que la única papeleta era la de su partido. A pesar del clima de violencia y del tipo de elección fraudulenta que fue, más de tres millones de alemanes votaron papeletas nulas dejando así constancia de su desacuerdo con Hitler. Cuarenta millones votaron por el Partido Nazi. El mundo estaba abocado a la catástrofe más absoluta.

La política nazi comenzó por depurar a la oposición, o a lo que quedaba de ella, en el interior de Alemania. La Gestapo, policía política nazi, comenzó la búsqueda de disidentes y opositores. Se limitaron los derechos de reunión y de expresión, la prensa fue censurada y los libros considerados peligrosos fueron prohibidos. En la depuración interna también fue eliminada la SA (Sección de Asalto), grupo paramilitar bajo las órdenes de Ernst Rohm, que obedecía en primer lugar a sus jefes y se mostraba decidida a hacerse con crecientes cuotas de poder dentro del partido y del Estado. Sus máximos dirigentes fueron asesinados y sus más de cuatro millones de hombres entraron en la SS o quedaron dispersos.

Tras la consolidación de Hitler en el poder la carrera hacia la guerra fue inmediata. La puesta en práctica de una política económica belicista activó la industria y la economía, convirtiendo a Alemania, en un quinquenio, en un país fuertemente armado y preparado para la guerra. Esta se desató tras la ocupación de Polonia en 1939 y la subsiguiente entrada de Francia y Gran Bretaña en el conflicto. La guerra fue fulgurante en sus inicios y Alemania conquistó buena parte de Europa. Salvo Gran Bretaña y los países aliados a Hitler, la ocupación alemana se extendió desde Francia hasta Stalingrado, quedando sitiadas Moscú y Leningrado. Hasta la decisiva batalla de Stalingrado, en el invierno de 1942/43, los avances alemanes eran constantes. Tras esa batalla y más adelante la de Kursk, en agosto de 1943, los nazis comenzaron a perder la guerra. En junio de 1944, con el desembarco de Normandía, el frente occidental comenzó a estrecharse para los alemanes. Quedaba poco menos de un año para la rendición total de Alemania, que se produjo en mayo de 1945. En el Pacífico, la guerra contra Japón concluyó tras el lanzamiento de las bombas atómicas de Hiroshima y Nagasaki, el 6 y el 9 de agosto de $1945^{24}$.

${ }^{24}$ Guerin, Daniel, La peste parda, Fundamentos, Madrid, 1977. KüHnl, Reinhard, Liberalismo y fascismo. Dos formas de dominio burgués, Fontanella, Barcelona, 1982. Toynbee, Arnold. J., La Europa de Hitler, Sarpe, Madrid, 1985. 

2. RECONSTRUCCIÓN CAPITALISTA Y GUERRA FRÍA 

Con la finalización de la Segunda Guerra Mundial, la humanidad entró en una nueva era. Los países que habían sido aliados contra los alemanes comenzaban a tener serias divergencias sobre el mundo de posguerra. Además, los acuerdos de Yalta y de Potsdam dibujaron un nuevo mapa geopolítico en función de las áreas de influencia de las dos superpotencias emergentes. De esta manera, EE.UU. y la URSS asentaron su dominio sobre gran parte de la superficie de la Tierra. En Europa, se dividió primero Berlín, luego Alemania y finalmente toda Europa en zonas de influencia soviética o norteamericana. Por Alemania pasó la línea de separación entre la Europa occidental y la oriental. Alemania quedó dividida entre una occidental, que se denominó República Federal Alemana (RFA), y otra oriental, denominada República Democrática de Alemania (RDA). Por su parte, Berlín quedó partido entre el occidental y el oriental. El resto de Europa se dividió entre los países que se denominaron occidentales, todos detrás de la RFA, y los orientales.

Fuera de Europa las potencias centrales se disputaron su influencia durante más tiempo. En Asia, la República Popular de China —fundada tras la Revolución china- engrosó las filas de los países comunistas aliados de Moscú. Por su parte, Japón quedó sometido a la ocupación norteamericana, igual que Filipinas y otros países de la zona. La disputa más violenta ocurrida allí fue en Corea, que finalmente, tras el armisticio de 1953, quedó dividida entre Corea del Sur, bajo ocupación norteamericana, y Corea del Norte, bajo la influencia chino-soviética. El conflicto de Corea, en el que murieron millones de hombres, es considerado la primera guerra de la guerra fría y colocó al mundo al borde de una catástrofe nuclear.

Por su parte, la India se independizó de Gran Bretaña en 1947, aunque el país se dividirá para dar nacimiento a Pakistán, también en $1947^{1}$. La India tuvo un papel activo e independiente durante la presidencia de Nehru, que llegó hasta 1964, año de su muerte. También jugó un papel muy importante en el nacimien-

${ }^{1}$ Metcalf, Barbara D. y Metcalf, Thomas R., Historia de la India, Cambridge University, Madrid, 2003. 
to del Tercer Mundo durante la Conferencia de Bandung, en 1955. En África, el movimiento por las independencias cobró protagonismo en 1960. América Latina estuvo bajo la influencia norteamericana de manera incontestable hasta la Revolución cubana de 1959.

Por tanto, el escenario europeo es central en el inicio y consolidación de la guerra fría. Es en Europa donde las grandes potencias mantienen la tensión político-militar con más determinación. Los norteamericanos y los soviéticos se fueron distanciando paulatinamente al finalizar la contienda mundial. Truman, que había sustituido a Roosevelt tras su fallecimiento en abril de 1945, a un mes de la rendición de Alemania, era más radical que su predecesor y encarriló la relaciones con la URSS por la vía de la tensión política y militar. Por su parte, Stalin, dictador de la URSS, no dudó en impulsar golpes de Estado y ocupaciones militares en los países en donde estaban acantonadas las tropas del ejército rojo.

La crisis en el continente europeo se precipitó con la guerra civil griega en 1947, que conllevó la intervención de los anglo-norteamericanos, la derrota de los partisanos (comunistas) y la reinstalación de la monarquía helena. Esta crisis, junto con las desavenencias y los enfrentamientos por Berlín, en el mismo año, tensionaron las relaciones entre las potencias. Stalin activó el Kominfort, un sustituto táctico de la disuelta III Internacional, y llevó a cabo el golpe de Praga, por medio del cual los comunistas acaban con el sistema pluripartidista y toman el poder en solitario. Ello, es cierto, venía a ser la respuesta de la URSS a los planes norteamericanos de injerencia en Europa, que habían cobrado cuerpo tras la firma del Plan Marshall en mayo de 1947. La URSS rechazó entrar en dicho plan por considerarlo una maniobra de los EE. UU. para afianzar su dominio sobre Europa, e igualmente obligó a que sus países satélites rechazasen la firma.

Esta serie de acontecimientos desencadenaron el nacimiento de la OTAN (Organización del Tratado del Atlántico Norte), que fue sancionado en abril de 1949. Venía precedida por la firma del pacto de Bruselas de marzo de 1948, por medio del cual los países del Benelux (Bélgica, Holanda y Luxemburgo) firmaban un acuerdo de mutua ayuda en caso de agresión externa. La URSS bloqueó Berlín en junio, obligando a que un puente aéreo abasteciese la parte occidental con los bienes necesarios. La escalada de medidas poco amistosas fue caldeando el escenario, ya sin vuelta atrás, aunque con algunos vaivenes hasta el final de la guerra fría en 1991 con la desaparición de la URSS.

Los primeros países que formaron la OTAN fueron: EE. UU. Gran Bretaña, Francia, Bélgica, Holanda, Noruega, Luxemburgo, Dinamarca, Islandia, Portugal, Italia y Canadá. En los años sucesivos se irían incorporando nuevos socios.

Paralelamente a la formación de las alianzas, las dos potencias centrales se comprometieron en una carrera militar, que conllevaba el desarrollo y producción masiva de armas nucleares. Los soviéticos hicieron su primera explosión atómica en agosto de 1949. El ensayo tuvo lugar en el noreste de Kazajistán. De 
esta manera los soviéticos entraron de lleno en el desarrollo de la tecnología nuclear, tanto para uso civil como militar.

La respuesta de la URSS a la formación de la OTAN llegó con la firma del Pacto de Varsovia, acaecido en mayo de 1955. Los soviéticos se tomaron su tiempo antes de formalizar la alianza militar. Primeramente, establecieron políticas bilaterales con cada uno de los países de la Europa oriental, firmando tratados de amistad, cooperación y ayuda mutua. En 1949 se firmó el tratado del COMECON (Consejo Económico de Ayuda Mutua), que tenía como prioridad levantar las economías de los países implicados. En 1949 firmaron Bulgaria, Checoslovaquia, Hungría, Polonia, Rumanía, Albania y la URSS. En 1950 se incorporó la RDA, en 1972 Cuba y en 1978 Vietnam.

La OTAN había continuado con su política de ampliación y en 1952 ingresaron Grecia y Turquía, países que, sin embrago, han mantenido históricas rivalidades territoriales entre ellos. Y con el ingreso de la RFA en mayo de 1955, diez años después del final de la Segunda Guerra Mundial, los soviéticos, como respuesta y en desacuerdo con que Alemania volviese a estar armada, impulsaron el Pacto de Varsovia, que fue rubricado el 14 de mayo de 1955. En el texto del tratado se hace mención explícita a los acuerdos de la ONU sobre uso de la no violencia en la resolución de conflictos: «Art. 1. Las Partes Contratantes se comprometen, conforme a la Carta de las Naciones Unidas, a abstenerse en sus relaciones internacionales de recurrir a la amenaza o al uso de la fuerza y a arreglar sus controversias internacionales por medios pacíficos, de tal manera que no se pongan en peligro la paz y la seguridad internacionales ${ }^{2}$. Esta cita de los acuerdos de la ONU plasmada en los artículos del Pacto de Varsovia la vemos igualmente recogida en el tratado de la OTAN. No cabe duda de que los gestos y las intenciones en la política internacional de posguerra estaban muchas veces alejados de la propia realidad.

Establecidos los equilibrios de fuerzas en el plano militar, las potencias operaron habitualmente por medio de terceros países, o de grupos opositores locales, de tal manera que la guerra se libró con baja intensidad a lo largo del globo, lo cual protegió a la humanidad de la catástrofe nuclear. Porque la guerra después de la energía atómica ya no sería tal y como se había conocido. La opción de la destrucción total de la vida sobre el planeta Tierra estaba encima de la mesa si alguno de los contendientes llevaba la tensión más allá de donde pudiese frenarse ${ }^{3}$.

${ }^{2}$ Http://www.historiasiglo20.org/TEXT/pactovarsovia.htm (visitado 29/12/2015).

3 Hefrer, Jean y Launay, Michael, La guerra fría, Akal, Madrid, 1992. McMahon, Robert, La Guerra Fría: Una breve introducción, Alianza, Madrid, 2009. 


\subsection{LA FUNDACIÓN DE LA ONU}

El impulso político para que las Naciones Unidas fuesen creadas al finalizar la contienda mundial se dio durante la Conferencia de Yalta, en febrero de 1945. A esa reunión asistieron Stalin, Churchill y Roosevelt. Era la continuación de otras reuniones precedentes que se habían producido desde que en enero de 1943 tuvo lugar la de Casablanca, en Marruecos. Los aliados preparaban la posguerra. A la reunión de Yalta le siguió la de Potsdam en los meses de julio y agosto de 1945. Los acuerdos de Yalta contemplaban la celebración de elecciones en la Europa liberada del poder nazi e impulsaron una primera conferencia en San Francisco para preparar la posterior que dará nacimiento a la ONU. Se abordó el asunto de la desmilitarización de Alemania, lo cual fue contemplado por las tres potencias como requisito básico para la paz y seguridad en el futuro. En dicha cumbre establecieron la división de Alemania en cuatro zonas de seguridad, cada una bajo el gobierno de uno de los aliados. También se incorporó el tema de las indemnizaciones de guerra, que Alemania debía pagar por los daños causados en los países que ocupó. Afrontaron asuntos relativos a las fronteras de la nueva Europa, sobre todo para los casos de Yugoslavia, Austria y Bulgaria. La URSS se comprometía a intervenir en Japón una vez que Alemania fuese definitivamente derrotada, y a cambio se quedaría la isla de Sajalín y las Kuriles. Por último, se decidió imponer un bloqueo a España, por considerar a la dictadura franquista una secuela del fascismo que de manera inmediata iba a perder la guerra en Europa. Tal bloqueo se levantó, primero con los acuerdos firmados con los norteamericanos en 1953, y posteriormente con la admisión de España en la ONU en 1955, conjuntamente con Portugal, siendo estos dos países las únicas dictaduras fascistas que sobrevivieron a la Segunda Guerra Mundial y a la derrota del fascismo.

En Potsdam volvieron a reunirse los tres de Yalta, pero tras el fallecimiento de Roosevelt en abril de 1945, el presidente norteamericano era entonces Truman, y tras Churchill perder las elecciones de julio de 1945 su sustituto fue el laborista Atlee. Los principales acuerdos rubricados estaban referidos a la devolución de territorios anexionados por los nazis, así como la separación de Austria y Alemania. Otros objetivos fueron la desmilitarización, desnazificación, descartelización (eliminación de cárteles económicos nazis) y democratización de Alemania. Llevaron a cabo lo suscrito en Yalta en cuanto a la partición de Alemania, añadiéndose una división similar para Berlín y Viena. Propusieron la persecución de los criminales de guerra nazis y la preparación del tribunal de Nüremberg, para llevar a cabo los grandes juicios contra el nazismo, en la que había sido la ciudad de los grandes congresos del Partido Nazi.

La Organización de las Naciones Unidas (ONU) se creó el 24 de octubre de 1945 en San Francisco (California). Rubricaron 50 países su Carta de principios y, en consecuencia, fueron miembros fundadores. La estructura de la ONU la componen el Consejo de Seguridad, la Asamblea General, el Consejo 
Económico y Social, el Consejo de Administración Fiduciaria, la Corte Internacional de Justicia y la Secretaría General. El Consejo de Seguridad es el organismo encargado de mantener la paz y seguridad entre las naciones. Está facultado para tomar decisiones, que se formulan en formato de resoluciones, por medio de las cuales se obliga a los miembros a su acatamiento, tal y como refleja la Carta fundacional. El Consejo está compuesto por representantes de 15 países, de los cuales cinco son permanentes y diez temporales y rotatorios. Los cinco miembros permanentes son los aliados que derrotaron al fascismo: EE. UU., URSS, Francia, China y Gran Bretaña ${ }^{4}$.

En la reunión de San Francisco sentaron las bases del orden internacional de posguerra. Los principios de la organización están recogidos en la Carta, la cual fue aprobada por una mayoría superior a dos tercios. Fue dividida en cuatro secciones. La primera especifica los propósitos generales, principios, miembros, Secretaría y enmiendas. La segunda definió los poderes y responsabilidades de la Asamblea General. La tercera se ocupó de los asuntos que competen al Consejo de Seguridad y la cuarta propuso el estatuto de la Corte Internacional de Justicia ${ }^{5}$.

Crearon un mecanismo específico para los territorios fiduciarios bajo administración de Naciones Unidas. Estos territorios debían correr una suerte paralela a la de las colonias y, por tanto, había que irlos preparando para que pudieran acceder a la independencia en las mejores condiciones posibles o, si no, al menos, a la consecución de un estatus de «gobierno propio». Este asunto ocupó de forma creciente el interés de NN.UU., y conjuntamente con el tema de las descolonizaciones fue escenario de disputas de poder. Muchas veces los territorios en régimen de fideicomiso actuaron de peones en el juego de las grandes potencias.

El 24 de octubre de 1945 la Carta de las NN. UU. entró en vigor y se puso en marcha su maquinaria. De ahí en adelante la ONU iba a tratar de ser árbitro en los conflictos regionales que azotaron al mundo en la era de las descolonizaciones y de las revoluciones antiimperialistas de las décadas posteriores.

${ }^{4}$ Kennedy, Paul M., El parlamento de la humanidad: La historia de las Naciones Unidas, Random House, España, 2007.

${ }^{5} \mathrm{Http} / /$ www.un.org/es/aboutun/history/sanfrancisco_conference.shtml (visitado $30 / 12 / 2015)$. 


\subsection{El nacimiento de la Europa unida bajo la hegemonía de EE. UU.}

La Comunidad Europea comenzó siendo un acuerdo interaduanero para determinados productos después de la Segunda Guerra Mundial. La rapidez con la que se recomponen las relaciones entre los Estados en Europa occidental, tras estar enfrascados en una cruenta guerra de cinco años, solo es explicable por la imperiosa necesidad que observa el eje anglo-norteamericano, pero sobre todo Estados Unidos, de construir un dique en el oeste de Europa que haga posible llevar a término los acuerdos del tratado de Yalta. El Plan Marshall, la presencia de las tropas norteamericanas en Europa occidental y la creación de la OTAN son tres elementos esenciales para que pueda llevarse adelante el proceso de «construcción europea».

«La Alianza Atlántica, encarnada institucionalmente en la OTAN, vincula a América a los Estados más influyentes de Europa, haciendo de los Estados Unidos un participante clave incluso en los asuntos intraeuropeos [...]. La supremacía estadounidense ha producido, por lo tanto, un nuevo orden internacional que no sólo duplica sino que también institucionaliza en el exterior muchas de las características del propio sistema estadounidense (OTAN, TLC, FMI, OMC...), procedimientos que hacen hincapié en la toma de decisiones por consenso, aunque dominada por los Estados Unidos [...]. La mayor parte de este sistema surgió durante la guerra fría como consecuencia de los esfuerzos estadounidenses para contener a su rival global, la Unión Soviética» ${ }^{6}$.

Los imperativos estratégicos de la política norteamericana dominan la escena mundial desde 1945, y en esa línea «el mantenimiento de la primacía internacional de los Estados Unidos es esencial para el bienestar y la seguridad de los estadounidenses y para el futuro de la libertad, la democracia, las economías abiertas y el orden internacional en el mundo» ${ }^{7}$. En este gran tablero mundial en que se ha convertido la política global, los estrategas norteamericanos contemplan a Euroasia como la principal pieza a conquistar. Se dice: quien gobierne Europa Central dominará el heartland; quien gobierne el heartland dominará la isla mundial; quien gobierne la isla mundial dominará el mundo. Todo ello requiere el establecimiento de alianzas (OTAN, UE, OCSE, etc.) controladas y dirigidas por la potencia hegemónica con el objetivo de someter «al corazón de la tierra». «Para usar una terminología propia de la era más brutal de los antiguos imperios, los tres grandes imperativos de la geoestrategia imperial son los

${ }^{6}$ Brzezinski, Zbibniew, El gran tablero mundial. La supremacía estadounidense y sus imperativos geoestratégicos, Paidós, Barcelona, 1998, pp. 36-38. Galván Fernández, Francisco y Martínez Azagra, Luis, Evolución y crisis global del capitalismo, Hacer, Barcelona, 1987.

${ }^{7}$ Huntington, Samuel P., «Why International Primacy Matters», International Security, citado en Brzezinski. 
de impedir choques entre los vasallos y mantener su dependencia en términos de seguridad, mantener a los tributarios obedientes y protegidos e impedir la unión de los bárbaros» ${ }^{8}$.

La conformación institucional de la UE ha desembocado en una estructura calcada de la de los Estados liberales, pero con menor legitimación democrática, si cabe, dado el carácter no electivo de casi todas las instancias fundamentales. Veámoslas brevemente:

1. El ámbito político decisivo lo componen tres organismos: el Parlamento Europeo, el Consejo de la Unión Europea y la Comisión Europea. De ellos, solo el Parlamento está sujeto a las normas de la democracia formal, es decir, sus componentes se eligen por sufragio universal. Los otros dos organismos no. No están sujetos, por tanto, a ninguna regla de comportamiento de la democracia representativa. A su seno asisten los gobernantes elegidos democráticamente en sus respectivos países. El Consejo de la Unión Europea —en donde se reúnen los ministros de los países miembros-, junto con la Comisión y el Consejo Europeo - compuesto por los jefes de Estado de los países miembros-, son los órganos decisivos de poder de la Unión. En ellos se legisla para la Unión. Se establecen los objetivos políticos, se coordinan las políticas nacionales y se resuelven las diferencias existentes entre ellos y con otras instituciones. Se regula la vida política y el desarrollo de la $\mathrm{UE}^{9}$.

2. El ámbito de las instituciones económicas está compuesto por el Tribunal de Cuentas Europeo, encargado de supervisar los usos de los dineros presupuestados, el Banco Europeo de Inversiones y el Banco Central Europeo, que son las principales instituciones financieras de la UE.

3. La tercera instancia básica es el Tribunal de Justicia de las Comunidades Europeas, organismo con creciente poder y cuyos dictámenes, en muchas ocasiones, se superponen jerárquicamente a los emitidos por los Estados miembros.

4. Por último, el resto de aparatos son de menor importancia y establecen solo recomendaciones en los marcos en los que están inscritos. Ellos son: el Comité Económico y Social, el Comité de las Regiones y el Defensor del Pueblo.

El 9 de mayo de 1950, la denominada Declaración Schuman impulsó la creación de un acuerdo interaduanero para el comercio del carbón y el acero entre Alemania, Bélgica, Francia, Italia, Luxemburgo y los Países Bajos, el Acuerdo CECA (Comunidad Europea del Carbón y el Acero). Se estimaba entonces que la manera de impedir nuevas guerras en Europa pasaba por crear lazos

${ }^{8}$ BRzezinski, B., op. cit., p. 48.

${ }^{9}$ Http://europa.eu.int/inst-es.htm. 
económicos interestatales que fuesen construyendo intereses comunes entre los países implicados. Después vino el Tratado de Roma, firmado el 25 de marzo de 1957, considerado como el que da inicio a la UE. El tratado tomó el nombre de Comunidad Económica Europea (CEE), y la idea básica consistía en la creación de un mercado común, al que se incorporan bienes y servicios, dando lugar a la supresión total de aduanas entre los países miembros (1968) y un control conjunto de la producción alimentaria, poniendo las bases de la política agraria común (PAC).

En enero de 1973 la CEE se amplió con la entrada de Dinamarca, Gran Bretaña e Irlanda. Fue el año de la crisis energética al subir bruscamente los precios del petróleo, lo que repercutió negativamente en la economía de la CEE. La subida estuvo motivada por la guerra árabe-israelí del Yom Kipur, de octubre de 1973. Unos meses más tarde, en abril de 1974, cae la dictadura de CaetanoSalazar en Portugal y, en noviembre de 1975, muere Franco, lo que abre nuevas perspectivas en España, con una clase financiera e industrial muy interesada en ser admitida en el seno de la Comunidad Económica. En 1975 la CEE crea el Fondo Europeo de Desarrollo Regional (FEDER) para intentar equilibrar los desiguales desarrollos entre los países de la Comunidad, y dentro de ellos las desigualdades regionales. En 1979, el Parlamento Europeo es elegido por primera vez por sufragio universal.

La década de los ochenta dio nuevo impulso y sentido a la CEE. Grecia (en 1981), Portugal y España (en 1986) se hacen miembros de pleno derecho, quedando de esta manera todo el flanco sur de Europa occidental dentro de la CEE y de la OTAN. En noviembre de 1989 cayó el muro de Berlín y se suceden acontecimientos de gran trascendencia. Se unifica Alemania, desaparece la Europa oriental como bloque político-militar y, en 1991, se desintegra la URSS, poniéndose fin a la guerra fría.

Desde 1985 la CEE abordó nuevos retos, los cuales fueron recogidos en el Libro Blanco, redactado bajo la presidencia, en la Comisión, de Jacques Delors. La idea fuerza del libro fue la creación del mercado único europeo, que quedó recogida en el Acta Única Europea, firmada en 1986 y cuya culminación estaba prevista en seis años. La base consiste en la eliminación de las trabas aduaneras a las mercancías y los capitales. De tal modo, entró en vigor el Tratado de Maastricht (1993) y se culminó el proceso de las «cuatro libertades» de circulación: mercancías, servicios, personas y capitales. El Tratado cambia la denominación de CEE por UE (Unión Europea).

A partir de entonces la UE se asentará en tres pilares, según la expresión acuñada por sus ideólogos. «El central, es el que se ha denominado el "pilar comunitario', es decir, el recogido en los Tratados comunitarios y sus diversas reformas, con sus instituciones con competencias supranacionales. En este pilar están recogidos el mercado único, la unión económica y monetaria, la PAC, los fondos estructurales y de cohesión. Los nuevos pilares, los laterales, estarían basados no en unos poderes supranacionales, sino en la cooperación entre los 
gobiernos: Política Exterior y Seguridad Común (PESC); Justicia y Asuntos de Interior $(\mathrm{JAI}) »^{10}$.

La década de los noventa fue testigo de nuevas ampliaciones. Además, se redefinió y amplió el Convenio de Schengen, el cual era una ampliación del acuerdo del mismo nombre firmado en 1985 por Bélgica, Francia, Alemania, Luxemburgo y los Países Bajos. Tras su conversión en convenio (1995), se extendió a los nuevos países, haciendo libre la circulación de los ciudadanos comunitarios entre los países signatarios. No todos los países están obligados a aceptar este convenio, solo les obliga el hecho de firmarlo. La UE incorporó tres nuevos miembros en 1995 (Austria, Finlandia y Suecia).

En 1999 entró en vigor el Tratado de Amsterdam, que había sido firmado en octubre de 1997 en dicha ciudad. El Tratado reseñó la naturaleza democrática de la UE, la defensa de los derechos humanos y del Estado social. Se establecieron mecanismos de cooperación policial, justicia e interior para los supuestos de terrorismo, racismo, xenofobia, tráfico de armas y de personas, así como contra la corrupción y el fraude, todo ello coordinado por la Europol. Se promovieron estrategias en la lucha contra la degradación medioambiental, el desempleo y en defensa de los consumidores. Queda garantizado el acceso de todos los ciudadanos a los documentos elaborados por las instituciones de la UE, los cuales serán servidos en algunas de las 12 lenguas oficiales. Acordaron la creación de la figura del Alto Representante para la Política Exterior y de Seguridad Común. Ese cargo será complementado con la Secretaría General del Consejo de la UE. La defensa y la política internacional deberán ser diseñadas junto a un futuro ejército europeo, que hasta la actualidad no ha terminado de concretarse. Introdujo reformas en las instituciones para ajustarlas a las necesidades de la integración de los nuevos miembros, que en ese instante estaban a las puertas. Todos los antiguos miembros del bloque soviético esperaban turno para entra en la UE.

La moneda euro entró en circulación para las transacciones financieras en 1999, y en 2002 pasó a ser de uso corriente para la ciudadanía de los países que la convirtieron en propia. Nueve países no han optado a su uso (Bulgaria, Croacia, Dinamarca, Hungría, Polonia, Reino Unido, República Checa, Rumanía y Suecia).

Fueron convocadas elecciones europeas (2004) con el objetivo de aprobar una Constitución. Con ello se quería dar el salto de los tratados hacia una ley superior, como en los Estados-nación. Hubo referéndum sobre el texto constitucional en algunos países. En Francia y Holanda la ciudadanía votó en contra, quedando de esa manera desechada la posibilidad de su aprobación en el conjunto de la Unión. Al fracaso constitucional le siguió el Tratado de Lisboa (2009). Ahí sancionan una Europa de contenido neoliberal, que va a marcar

${ }^{10}$ Http://clio.rediris.es/udidactica/maastricht.htm (visitado 31/12/2015). 
las políticas de la Unión en adelante. Aunque formalmente los contenidos sociales de los distintos tratados siguen vigentes, la crisis financiera de 2008 y sus secuelas han hecho que la UE se decante por las opciones neoliberales en un escenario de competencia, frente a los países asiáticos y los EE. UU. En 2004, diez nuevos países ingresan en la Unión, y en 2007 lo hacen otros dos. Croacia (2013) concluye, de momento, el proceso de ampliación de la UE, que ahora está compuesta por 28 países $^{11}$.

11 Gil Pecharromán, Julio, Historia de la integración europea, UNED, Madrid, 2012. Http://europa.eu/about-eu/eu-history/index_es.htm (visitado 17/5/2016) 
3. DESCOLONIZACIONES Y TERCER MUNDO 



\subsection{El COlONiALismo}

El colonialismo es una de las caras del proceso de la modernidad, del capitalismo y de la Edad Contemporánea. Las descolonizaciones suponen el intento de las periferias de tomar las riendas de sus propios destinos.

El colonialismo contemporáneo (no hablaremos aquí del surgido entre los siglos xv y xvıII, que, aunque está inserto en la misma lógica, escapa al propósito de este texto) se centró sobre todo en África y en Asia. América Latina había accedido a su independencia en las primeras décadas del siglo xIx, a excepción de algunas islas del Caribe, que lo hicieron más tarde. La expansión colonial del XIX estuvo motivada por las necesidades crecientes del capitalismo europeo de dar respuesta a nuevas exigencias derivadas de su desarrollo económico.

Algunas de las características básicas del colonialismo decimonónico, también denominado imperialismo, tienen que ver con la necesidad de exportación de los capitales acumulados en Europa. El desarrollo de las tecnologías y de la economía demandó la conquista de nuevos mercados. Así, se producen préstamos en forma de créditos a las minorías gobernantes de los territorios colonizados que fuesen aliadas de las potencias, a la vez que se invierten grandes sumas en megaproyectos ferroviarios, de puertos o de obras como el canal de Suez o el de Panamá. Estas inversiones son necesarias para la expansión del comercio mundial. Ello hace urgente la exploración de nuevas zonas para la búsqueda de materias primas que abasteciesen la demanda de la industria europea. El colonialismo promueve un uso intensivo de mano de obra barata, o esclava, lo que hace altamente productivo el negocio extractivo y su exportación hacia los centros capitalistas.

Las grandes necesidades del nuevo capitalismo estaban asociadas al nacimiento y creación de los grandes monopolios, los cuales aparecieron por primera vez en la década de 1860-70. Para principios del siglo xx estas grandes empresas, monopólicas o de cárteles, dominan la economía mundial. A ellas se sumó el capital financiero, que sirvió de apoyo importante para la financiación de los grandes proyectos y de los planes expansivos del capitalismo. Había todo un mercado mundial que someter a las leyes del capital.

Entre los nuevos grandes trust destacaron, por el papel central para la producción, las industrias petroleras. El mercado mundial del petróleo estaba dominado por siete grandes empresas. Las «siete hermanas» eran Standard Oil 
of New Jersey (EE.UU.), Standard Oil of New York (EE.UU.), Standard Oil of California (EE. UU.), Gulf Oil Corporation (EE. UU.), Texaco (EE. UU.), Royal Dutch Shell (Holanda-Gran Bretaña) y Anglo Iranian Oil Company, luego denominada British Petroleum (Gran Bretaña). Estos gigantes controlaron el sector durante muchas décadas. Después se reorganizaron, y algunas más, de otros países, entraron a formar parte del selecto club de las grandes compañías petroleras del mundo.

Estas compañías petroleras son el vértice del nuevo capitalismo, junto con la gran banca y las grandes industrias. Todo ello generó un escenario con unas características que podemos resumir en las siguientes:

1. La producción logró altas cotas de concentración, lo que produjo asimismo grandes concentraciones de capital.

2. Creación de una oligarquía mundial financiera, producto de la fusión del capital financiero y el industrial.

3. Generalización de la exportación de capitales y mercancías al mercado mundial.

4. Nacimiento de grandes empresas monopolistas que controlan el mercado mundial.

5. Conquista de todas las zonas geográficas del mundo, que entran a formar parte del capitalismo global, aunque en régimen de sobreexplotación.

Todo lo anterior fue acompañado de teorías racistas acerca de la superioridad blanca, el paternalismo hacia las culturas no europeas, la actividad misionera de conversión a la fe cristiana y un discurso de fuerte componente eurocéntrico. Paralelamente, las potencias coloniales están en disputa entre sí: cada una pretende controlar más territorios y recursos que su competidora, lo cual genera tensiones por el control de los mares y los continentes. Tras disputas de diversa índole, estos conflictos terminan por desatar la Primera Guerra Mundial.

La distribución del poder colonial quedó de la siguiente forma. Los británicos se hicieron con la mayoría de las colonias y con el control de los mares. Su imperio se extendió por Asia, desde la India hasta Malaca, Singapur y Birmania, así como importantes posesiones en China, donde controlaban, en parte, los puertos y el comercio. En África poseyeron Egipto de forma interpuesta, compartiendo el control con los franceses, además de Sudáfrica, Zimbabwe, Zambia, Nigeria, Somalia, Kenia, Uganda y Sudán. En Oceanía, Nueva Zelanda y Australia; y en América, Canadá, Honduras, Jamaica y Guayana.

Por su parte, Francia, que fue el segundo imperio más importante, extendió su dominio por todos los continentes también. En Asia, Indochina. En Oceanía, Nueva Caledonia, Tahití e islas Marquesa. En América, archipiélago Miquelon y Guyana. En África, Argelia, Túnez, Marruecos, Congo francés, Senegal, Guinea, Costa de Marfil, Benin, Chad y Madagascar.

Las otras potencias europeas con imperios coloniales fueron Alemania (Togo, Camerún, Tanganika y, en Oceanía, Nueva Guinea, Carolina y Marianas), 
que perdió sus colonias tras la Primera Guerra Mundial; Italia (Eritrea, Libia); Bélgica (Congo); Portugal (Angola, Mozambique, Guinea Bissau y Cabo Verde); y España (Ifni, Sahara, Guinea Ecuatorial). Todo ello fue repartido, en lo que respecta a África, en la Conferencia de Berlín de 1885.

Por su parte, los norteamericanos centraron su expansión primero en el interior del país, con la penetración hacia el oeste y la usurpación de tierras a los indígenas y a los mexicanos. Compró Alaska a los rusos y se hizo con Cuba, Puerto Rico y Filipinas tras haber sido expulsados los españoles. Por último, Japón extendió su dominio a Manchuria, en China, Formosa y Corea.

Este reparto del mundo fue cambiante a lo largo del siglo y, tras la Segunda Guerra Mundial, las viejas y grandes potencias europeas fueron desplazadas en beneficio de los EE. UU., que ejercían su dominación por un tipo de mecanismo distinto a los del colonialismo clásico ${ }^{1}$.

Después de 1945 se abrió de manera masiva la opción de las descolonizaciones. Las colonias, que habían sido testigo de las matanzas y la brutalidad de la guerra, iniciada en el corazón de Europa, entendieron que el hombre blanco no era tal como él mismo hablaba de sí. Su civilización, que pretendía ser el faro de la humanidad, se mostró despiadada y terrorífica hasta cotas nunca vista por el hombre. Tras el descubrimiento de los campos de exterminio nazis, y después del uso de las bombas atómicas, la modernidad europea mostró su lado más antihumanista. Del ciclo de los horrores se supo también en el interior de la URSS. El modelo socialista de superación al capitalismo se había hundido en los campos del gulag.

Pensadores de lo que se denominó el Tercer Mundo después de Bandung (1955) hicieron una revisión del pensamiento occidental y de su componente racista. En especial dos caribeños, Aimé Césaire y Frantz Fanon, sentaron las bases del pensamiento anticolonial, a la vez que por Asia comenzaban las luchas de liberación nacional, que terminaron expulsando a los europeos de sus colonias.

La destrucción de las culturas tradicionales fue un arma usada intencionadamente por los colonialistas, para después remarcar la superioridad europea. Se difundió de manera forzada y muchas veces violenta la «cultura occidental», ahondando en la humillación del colonizado y en la infravaloración de su mundo. Césaire denuncia el hecho y lo califica como «deshumanización» que separó a «millones de hombres (de sus dioses y su tierra) de su vida, costumbre, clase y sabiduría». Césaire se niega a admitir que eso pueda ser llamado civilización o progreso humano, y dice: «Se me habla de progreso, de realizaciones, de enfer-

1 Ferro, Marc (dir.), El libro negro del colonialismo, La esfera de los libros, Madrid, 2003. Iniesta, Ferran y Kuma. Historia del África negra, Bellaterra, Barcelona, 2000. KI-ZERBo, Joseph, Historia del África negra. De los orígenes a las independencias, Bellaterra, Barcelona, 2011. 
medades curadas, de niveles elevados de vida. Yo, por mi parte, hablo de sociedades vaciadas de sí mismas, de tierras confiscadas, de religiones asesinadas, de magnificencias aniquiladas, de extraordinarias posibilidades suprimidas ${ }^{2}$. Junto a este teórico, Fanon nos habla de que «es el racista el que crea la inferioridad», parafraseando a Sartre, quien decía que era «el antisemitismo el que había creado al judío». Para Fanon la ruptura del colonialismo debe implicar el nacimiento de un hombre nuevo, despojado de toda la violencia de desposesión a que había sido sometido por el pensamiento colonial. «Hay que elevar al pueblo, ampliar el cerebro del pueblo, llenarlo, diferenciarlo, humanizarlo, [...] compañeros, hay que cambiar de piel, desarrollar un pensamiento nuevo, tratar de crear hombres nuevos» ${ }^{3}$. Estos autores trataron, y consiguieron en buena medida, un pensamiento propio que impugnaba el del colonizador, que hasta entonces era hegemónico en las mismas colonias.

Podríamos decir que estos teóricos comenzaron a deconstruir el pensamiento colonialista, que se había impuesto como el verdadero desde la misma conquista de América en el siglo xv. A este respecto, el pensamiento colonialista del siglo xix y parte del xx era una versión actualizada del viejo pensamiento colonialista del 1500. «El debate teológico del siglo xvi sobre si se tenía alma o no (el indio), o sobre la justeza de la conquista, tuvo la misma connotación de los debates cientificistas del siglo XIX sobre si se tenía la constitución biológica humana o no (el negro). Ambos fueron debates sobre la humanidad o la animalidad de los 'otros', articulados por el discurso racista institucional de Estado de la monarquía cristiana castellana en el siglo xvi o de los Estados naciones imperiales europeo-occidentales en el siglo XIX. Estas lógicas racistas institucionales de 'no tener alma' en el siglo xvi o 'no tener la biología humana' en el siglo xix devinieron el principio organizador de la división internacional del trabajo y la acumulación capitalista a escala mundial» ${ }^{4}$.

\subsection{Descolonización}

Las masivas independencias africanas, que cobran un impulso fabuloso en 1960, modificaron las relaciones políticas internacionales y con ello la geopolítica global. A partir de esas independencias, se entra en una nueva era en las relaciones entre los países del sur y los del norte, siempre, claro está, en una perspectiva de

${ }^{2}$ CÉSAIre, Aimé, Discurso sobre el colonialismo, Akal, Madrid, 2006, p. 20.

${ }^{3}$ Fanon, Frantz, Los condenados de la tierra, FCE, México, 1963, p. 97.

${ }^{4}$ Grosfoguel, Ramón, «Racismo/sexismo epistémico, universidades occidentalizadas y los cuatro genocidios/epistemicidios del largo siglo XVI», en Tabula Rasa, BogotáColombia, n. ${ }^{\circ}$ 19: 31-58, julio-diciembre 2013. 
dominación y de intento de mantenimiento del control de la situación por parte de los países europeos y los EE. UU. Las relaciones dejarán de ser de dominación colonial directa con administración y tropas en el territorio ocupado, y pasarán a ser de dominio indirecto por medio de estructuras y empresas transnacionales, sin descartar intervenciones directas cuando la situación lo requiera. Pero el neocolonialismo no se limita solo a una dominación de naturaleza económica, sino que sus métodos son también visibles en los campos de la política, la religión, las ideologías y la cultura ${ }^{5}$.

Los mecanismos de control en el terreno de la economía van a condicionar a los otros campos. Los países africanos, subdesarrollados tras decenios de sojuzgamiento a las potencias occidentales, se verán obligados en muchos casos a entablar negociaciones en términos de desigualdad absoluta con las antiguas potencias y con las agencias internacionales controladas por ellas. En concreto, organismos tales como el FMI, el BM, la Corporación Financiera Internacional y la Agencia Internacional de Desarrollo están controlados por las potencias occidentales, sobre todo por los EE. UU. Recibir préstamos de ellas, ineludible si se quieren impulsar políticas hacia el desarrollo, implica volver a ceder soberanía a los países del norte. Los préstamos se reciben siempre y cuando se apliquen las políticas que estos organismos decidan, lo que los convierte en supervisores de la economía de estos países. Esa política es maquillada por las agencias internacionales citadas y los países desarrollados como de ayuda al desarrollo para ocultar su verdadera naturaleza, que no es otra que mantener el control sobre los países emergentes. Algunas de las condiciones exigidas son: «La firma de tratados de navegación y comercio; los convenios para cooperación económica; el derecho de inmiscuirse en las fianzas internas, inclusive en la moneda y el cambio exterior, para disminuir las barreras arancelarias en favor de los artículos y el capital del país donante; la protección de los inversionistas del capital privado; la determinación respecto al empleo de los fondos; la obligación para quien los recibe de constituir fondos equivalentes; el suministro de materias primas al donante, y el uso de tales fondos - la mayoría, de hecho- para comprar bienes de la nación donante. Estas condiciones se aplican a la industria, al comercio, a la agricultura, a la navegación y a los seguros, aparte de otras de índole política y militar» ${ }^{6}$.

Si los controles económicos no son suficientes, porque los nuevos dirigentes nacionalistas africanos tienen en sus planes sacar a sus países del subdesarrollo, entonces se emplean mecanismos de otra índole. El más notorio es el golpe de Estado o el asesinato de los dirigentes de masas de los países implicados. Tras operar en el mundo sindical y debilitar a los sindicatos de clase cuyos jefes no se avienen a corromperse, se pasa al escenario de la política. Las intervenciones

\footnotetext{
${ }^{5}$ Nkrumah, K., Neocolonialismo, última etapa del imperialismo, Siglo xxi, México, 1966.

${ }^{6}$ Ibíd., p. 207.
} 
abiertas, como en el Congo, concluyen con el asesinato del dirigente nacionalista (Lumumba), y luego, décadas de un régimen cleptómano y sanguinario (Mobuto) sentencian por tiempo indefinido las posibilidades de que ese país salga del subdesarrollo. En otros casos, la expulsión de dirigentes y su forzada huida al exilio dejan al país sin cuadros políticos nacionalistas antiimperialistas (Ghana), o bien la imposición de una guerra generalizada de años retrasa el acceso al poder de los dirigentes nacionalistas (Argelia). Todo va acompañado de imposiciones político-militares espantosas, como la exigencia y consecución de la instalación de bases militares en el país objeto de la operación, el suministro de material militar y la preparación y formación de los cuadros del ejército, por medio de consejeros que se encargan de adiestrar y formar, ideológicamente, a los que de hecho serán sus futuros agentes nativos en el país en cuestión. Paralelamente se presiona para firmar tratados de explotación de recursos estratégicos, si el territorio es poseedor de ellos, como de hecho ocurre en casi todos los países africanos.

Acompañando a esas medidas se promociona por medio de los aparatos culturales (cine, radio, televisión) abundante ideología afín al país ocupante y se ejerce un control absoluto de las agencias de información de noticias, que actúan como estiletes contra el pensamiento nacionalista y de liberación nacional en estas naciones emergentes. No menor papel desempeña la promoción de sectas religiosas evangelistas norteamericanas, que predican normalmente la desafección a las ideas y los símbolos nacionalistas de tales países (rechazo a la bandera, condena de la militancia política, estimular el compromiso solo con las cosas del más allá invitando a la no participación en los asuntos del país, etc.).

Las operaciones secretas para desestabilizar a los dirigentes y países anticolonialistas han sido una constante de las políticas africanas de las antiguas metrópolis y de los EE. UU. Antes y después de 1960 los servicios secretos norteamericanos han llevado a cabo reuniones secretas, simposios, seminarios y encuentros formales e informales para promover la guerra ideológica y psicológica en África, utilizando el marco de la CIA, de la OTAN y de otras agencias menos conocidas, para controlar a los países o movimientos, también europeos, que consideraban comunistas o filocomunistas. Dada la amplia definición que hacían del concepto, cualquiera que no se atuviese a la demanda exacta que el Gobierno de EE. UU. reclamase en cada momento podría entrar en esas categorías. Por supuesto que belgas, franceses, ingleses y portugueses actuaban bajo los mismos principios, estos últimos con menor proyección dado su menor poder.

Esas conductas de los países imperialistas tenían su fundamento en la creciente pérdida de influencia que experimentaban sobre los, hasta entonces, países sometidos a su autoridad. Tras la Segunda Guerra Mundial comenzaban a hacerse evidentes las reclamaciones de independencia en multitud de territorios de varios continentes. En África, en 1946 se constituyó la RDA en Bamako. El Reagrupamiento Democrático Africano pretendió unir a los partidos y movimientos del África francesa para elaborar un programa común mínimo. En 1947 se produjo en Madagascar un levantamiento nacionalista que fue seguido de una 
sangrienta represión por parte de las tropas francesas. En Camerún (1948), los independentistas crean la Unión Popular de Camerún e inician un proceso de lucha armada (1955) que es reprimido duramente por las tropas francesas en 1961. Nkrumah se convierte en jefe de Gobierno de Ghana (1951), aunque aún bajo dominación colonial, y proclamará la independencia en 1957. Derrocado por un golpe de Estado en 1966 (auspiciado por la CIA), debe huir del país para morir en el exilio en 1972. En todo el continente los movimientos políticos se desatan aunque con tendencias diferenciales. Sokou Touré (1958) lidera la independencia de Guinea Conakry.

El impulso de los procesos independentistas en Asia iba a estar detrás del despertar africano. La independencia de la India vehiculó su influencia hacia África a través de la Liga Árabe y por medio de dos dirigentes de países emergentes que se convirtieron con el tiempo en referencia obligada del anticolonialismo: el hindú Nehru y el egipcio Nasser. En la Conferencia de Nueva Delhi de 1949, los Estados asiáticos y dos africanos reclamaron la independencia de Indonesia, y además crearon un grupo de países asiáticos, árabes y africanos en la ONU, conformado por Afganistán, Birmania, la India, Indonesia, Irán, Pakistán, Arabia Saudí, Egipto, Irak, el Líbano, Siria, Yemen, Etiopía y Liberia. Todos ellos trataban de impulsar una política independiente de los bloques y tenían muchos puntos de acuerdo en la cuestión colonial ${ }^{7}$.

El empuje definitivo a esa tendencia se daría en la Conferencia de Bandung, en 1955, a la que asistieron veinticuatro países asiáticos, entre los que se encontraban los cinco anfitriones (Birmania, Ceilán, la India, Indonesia y Pakistán), además de los países africanos Egipto, Etiopía, Ghana, Liberia, Libia y Sudán. La mayor parte del territorio africano aún seguía bajo dominación extranjera. También asistieron observadores del Magreb. La delegación más poderosa era, sin duda, la china, que iba bajo el mando de Zhou Enlai.

El nacimiento del Tercer Mundo como sujeto político (sometido a multitud de contradicciones) engendró y encarnó durante décadas la esperanza de construcción de un mundo en el que no tuviesen lugar el colonialismo ni el imperialismo. Catalizó la esperanza de millones de personas, y en la práctica supuso un retroceso evidente de las potencias europeas y norteamericana en cuanto a su control efectivo del mundo. En el discurso del presidente Sukarno durante la Conferencia de Bandung, este dijo: «No nos amarguemos por el pasado y fijemos imperturbables la vista en el futuro. Recordemos que no hay bendición divina más dulce que la vida y la libertad. Recordemos que la estatura de la humanidad en su conjunto se verá mermada mientras continúe habiendo naciones enteras (o

7 Grimal, H., Historia de las descolonizaciones del siglo Xx, Iepala, Madrid, 1989. ArACIL, Rafael, Oliver, Joan y Segura, Antoni, El mundo actual. De la segunda guerra mundial a nuestros dias, Universidat de Barcelona, 1998. 
partes de ellas) desprovistas de libertad. Recordemos que el fin más elevado del hombre es liberar al propio hombre de sus ataduras de miedo, de sus ataduras de pobreza, de las ataduras físicas, espirituales e intelectuales que durante tanto tiempo han frenado el desarrollo de la mayoría de la humanidad. Y recordemos, Hermanas y Hermanos, que nosotros, asiáticos y africanos, debemos permanecer unidos en aras de todo lo anterior ${ }^{8}$. Las viejas potencias imperialistas acometerían la tarea, por cualquier medio, para que esas palabras no pudiesen convertirse en realidad en las décadas siguientes, y con ello un cambio en la centralidad del conflicto se produjo en la escala mundial. Las luchas antiimperialistas centrarían la potencia de cambio en las sociedades del Tercer Mundo hasta el final de la guerra fría. El nacionalismo anticolonialista y el comunismo caminaron juntos una buena parte de ese tiempo, y ambos fueron confundidos por sus enemigos, que prefirieron simplificar el discurso diciendo al mundo que luchaban contra el comunismo, siendo esto solo una parte de la verdad.

El imperialismo, además del uso intensivo que hizo de las prácticas de la guerra y la desestabilización interna, apostó por fracturar el movimiento de los países emergentes apoyando de entre ellos a los representantes del tradicionalismo y del nacionalismo cultural reaccionario. Usó de manera intensiva el islamismo desde fecha tan temprana como 1962 con el patrocinio a la Liga Mundial Musulmana y el apoyo a la reaccionaria Arabia Saudí como guardián de la ortodoxia musulmana. El islamismo fanatizado promovido desde entonces ha sido un estilete en manos de las clases reaccionarias del Tercer Mundo en los países islámicos y en los EE. UU. Las potencias imperialistas promocionaron el uso del tribalismo reinventándolo a partir de ideas atávicas, apoyando con ello los nacionalismos de corte cultural excluyente y no antiimperialista. Se destruyeron los pilares de las soberanías nacionales en los países emergentes: «Socavando la idea del nacionalismo, un conjunto de fuerzas sociales conservadoras y de clases poderosas unieron sus fuerzas para ofrecer una visión alternativa del patriotismo [...]. El nacionalismo laico-socialista del programa tercermundista se apagó ante el ascenso de la estrella del nacionalismo cultural, un nacionalismo cultural profundamente imbuido de diferencias raciales y religiosas, entre otros atavismos parecidos» ${ }^{9}$.

Las maniobras de las potencias colonialistas estaban en plena sintonía con la lógica de mantenimiento del poder en la escala global. Las potencias, que, sin embargo, tenían sus propias contradicciones internas - claramente visibles en el hecho de que existía un flanco anglosajón (Gran Bretaña y EE. UU.), que pretendía un dominio también extensivo sobre sus aliados, particularmente

${ }^{8}$ Citado en Prashad, V., Las naciones oscuras. una historia del tercer mundo, Península, Barcelona, 2012, pp. 17-18.

9 Ibíd., p. 454. 
Francia y Alemania, preocupándose de mantener alejada a la URSS de una entente con las potencias continentales-, pudieron sostener por encima de sus contradicciones estrechas alianzas para seguir dominando al Tercer Mundo. «La era de Bandung 1955-1975 y el apoyo que la Unión Soviética y China les dieron [...] [obligó] al imperialismo a actuar, no solamente aceptando la coexistencia pacífica con un área vasta que se les escapaba ampliamente ('el mundo socialista'), sino también negociando los términos de la participación de los países de Asia y África en el sistema mundial imperialista. La alineación del colectivo de la tríada bajo el liderazgo americano parecía un hecho inútil para poder dominar las relaciones Norte-Sur de la época. Esta es la razón por la cual los No Alineados se encontraron confrontados frente a un 'bloque occidental' prácticamente sin fallas ${ }^{10}$. El fortalecimiento de las clases reaccionarias en el interior de los países intervenidos formaba parte de esta estrategia de dominación global.

En cualquier caso, el impulso anticolonialista llegó a África para quedarse. En 1960, diecisiete países acceden a la independencia, algunos más a lo largo de la década, y entre ellos muchos habían comenzado sus procesos de liberación en la década de los cincuenta. Hubo procesos que fueron conducidos por la vía del pacto, como Nigeria, y otros tuvieron que recurrir a la vía armada, como Argelia y posteriormente Angola, Mozambique o Guinea Bissau. Algunos se quedaron a medio camino entre proceso de liberación y vuelta de las potencias coloniales, como fue el caso del Congo, en donde las fuerzas imperialistas conspiraron desde el primer momento para que el proceso de independencia quedase frustrado (asesinato de Lumumba) y se instalase inmediatamente un Gobierno corrupto y prooccidental (Kasavubu-Tshombe-Mobuto). También en Togo, el dirigente Sylvanus Olympio fue asesinado en 1963. Olympio pretendía sacar a su país de la dependencia económica francesa impulsando una participación masiva de los togoleses en la economía y permitiendo que otras potencias invirtieran capitales. Cuando los franceses fueron expulsados de Argelia en 1962, lo que saludó positivamente, temió que las tropas desmovilizadas fueran enviadas a su país y a otros del África subsahariana. «Me temo que las tropas africanas que serán desmovilizadas serán causa de problemas en nuestro país» ${ }^{11}$, le comentó a su hijo ${ }^{12}$.

${ }^{10}$ Amin, S., «Geopolítica del imperialismo contemporáneo», en Nueva Hegemonía Mundial. Alternativas de cambio y movimientos sociales, Boron, Atilio A. (compilador). CLACSO, Consejo Latinoamericano de Ciencias Sociales, Buenos Aires, Argentina, 2004, p. 4.

${ }^{11}$ Agbobli (A.), Un destin tragique, SOUTH livre, NEA, Senegal, 1992.

12 Olympio, hallándose de hecho ligado al neocolonialismo francés, tenía preferencia por la Alemania de Bonn y por Estados Unidos. Lo manifestó demasiado claramente. En diciembre de 1962, cuando las relaciones Togo-Ghana estaban aún más tensas que de costumbre, Francia propuso a Olympio una ayuda militar, bajo la forma de refuerzos de paracaidistas; Olympio se negó a ello, al igual que había rehusado firmar los acuerdos de cooperación militar. Se había negado igualmente a proporcionar empleo a los para- 
En los dominios franco-británicos la guerra civil no fue tan usada como en el caso de los territorios bajo dominación portuguesa, en los cuales la dictadura de Salazar usó de forma profusa la enemistad creada o imaginaria de los diferentes pueblos que vivían bajo su administración. «Los colonizadores portugueses supieron entonces enemistar a los pueblos autóctonos entre sí y reclutar a numerosos soldados entre los ovimbundus (39\% de la población de Angola)». Cuando los portugueses se retiran tras la Revolución de los claveles, nuevas potencias ocupan su lugar (EE. UU. y Sudáfrica) y mantienen las tácticas de separación de las comunidades nativas para combatir la influencia de la URSS y de Cuba, que entonces eran los apoyos del MPLA (Movimiento Popular de Liberación de Angola). Así, la lógica de la guerra fría entraba en escena sobre países que aún no habían tenido la opción de elegir, si es que querían elegir el bloque al que preferían pertenecer.

Desde el amanecer de los procesos por la independencia, EE. UU. pretendió heredar la hegemonía en la zona y concibió todo el proceso en clave de su enfrentamiento con la URSS, lo cual le granjeó problemas, conflictos y malos entendidos durante todo el tiempo. El conflicto en el Congo, que es el principal de los sucedidos en 1960, tanto por la extensión del país como por el alcance histórico que ha tenido posteriormente, estuvo completamente condicionado, en cuanto a la política norteamericana en el país, por las elecciones que iban a tener lugar el 8 de noviembre de 1960. La Administración norteamericana y su personal destacado en Congo, en particular su embajador Timberlake, veían con temor el cambio que podría introducir el nuevo Gobierno de Kennedy en la política internacional. «No parece descabellado suponer que gran parte de la sensación de emergencia de las primeras semanas de enero (1961), que condujo a la muerte de Lumumba, no se debía a la situación interna del Congo, por muy problemática que fuera, sino al temor a un cambio inminente en Washington ${ }^{13}$. Desde esta visión extremista del propio embajador y de la Administración norteamericana en los asuntos para África, se estaba firmemente convencido de que todo lo que no significase un control férreo de los norteamericanos en el continente africano era inmediatamente una oportunidad para la instalación de los soviéticos en la zona. La diplomacia estadounidense veía más marxistas de los que había, y aunque no lo fuesen, como en el caso de Lumumba, eran etiquetados de tales y eliminados cuando las circunstancias lo permitiesen.

La diplomacia norteamericana encumbró al cleptómano y sanguinario Mobuto, precisamente por el espejismo comunista que creía ver en todas partes,

caidistas togoleses desmovilizados por Francia y llegados a Togo. Poco después de estas negativas, cayó asesinado. BEnot, Yves, Ideologías de las independencias africanas, Dopesa, Barcelona, 1973, p. 111.

${ }^{13}$ Huband, M., África después de la guerra fría, Paidós, Barcelona, 2004. p. 41. 
y esta lógica la reprodujo en otros escenarios de África, Asia y Latinoamérica. Aunque el conflicto estuviese lejos de ser una reproducción local de la guerra fría, los agentes de la CIA destacados en el Congo lo reducían a esa particularidad ${ }^{14}$. «En la terminología de suma cero de la Guerra Fría, el éxito estadounidense era un fracaso soviético. Mobuto cerró la embajada soviética después de su golpe de estado, y la desaparición de Lumumba puso fin a todas las tibias oportunidades que pudieran haber tenido los soviéticos de incrementar su influencia a expensas del oeste» ${ }^{15}$.

Las maniobras de todo orden orquestadas por las viejas y las nuevas potencias van a dificultar la construcción del espacio poscolonial. Este lo será sin duda en el aspecto político, pero no en el de la independencia económica. Lo poscolonial tiene en África una naturaleza compleja. La independencia política se ha visto permanentemente cortocircuitada por la acción de las potencias, y a la vez por la emergencia de una elite en los nuevos países que ha reproducido mecanismos de control y opresión, en algunos casos superando las barbaries del poder colonial, pero la existencia de estas elites no se explica sin el apoyo y la interferencia permanente de las viejas potencias colonialistas y de los Estados Unidos. La geopolítica en África ha oscilado en estos últimos cincuenta años desde el escenario impuesto de teatro de operaciones de la guerra fría a una nueva realidad dominada por el control de los recursos locales en la que participan de forma competencial los Estados europeos y africanos, organismos financieros internacionales, multinacionales y grupos no estatales con poder de fuego y de bloqueo institucional. En el mundo poscolonial el conflicto no se ha apaciguado, sino que, bien al contrario, ha adquirido nuevas formas de expresión y de dimensión. La esperanza del momento de las independencias no se ha visto recompensada con el paso del tiempo. La era de las independencias llevó a cabo la condición necesaria, pero no la suficiente, para la verdadera consecución de un mundo poscolonial en todos los sentidos. Esta situación continuará en la medida en que los mecanismos de desposesión sigan operando como el criterio rector en la economía mundial.

A principios de la década de los sesenta ya estaba medianamente claro que «por primera vez en la historia de la humanidad los recursos materiales potenciales del mundo son tan grandes que no hay necesidad de que haya ricos y pobres: Lo único que falta es la organización para explotar esos recursos potenciales. La verdadera presión mundial puede obligar a esa nueva forma de explotación, pero la presión mundial no se ejerce mediante apelaciones, no importa lo elocuente que sean, o empleando argumentos, no importa cuán convincentes sean. Solo puede

14 Ibíd.

15 Schatzberg, M., «Mobutu or chaos: The United States and Zaire, 1960-1990», en Huband, op. cit., p. 41. 
lograrse con hechos» ${ }^{16}$. Desde esta óptica es solo la acción política la que puede recomponer una diferente correlación de fuerza en la escala internacional, que evite la guerra y la explotación de «tal manera que quien son ahora las víctimas desvalidas [...] en el futuro sean capaces de ejercer una presión contraria» a la que sufren bajo las normas del neocolonialismo. Los juegos geopolíticos han sometido al continente africano tras el fin de la guerra fría, y la herencia de los Estados de la primera independencia, a una fragmentación acelerada. Los procesos de guerras continuadas en muchos de los países solo aseguran victorias momentáneas a cualquiera de las fracciones, para más adelante retornar al punto de partida. Ese fenómeno se ve acelerado por la internacionalización del intercambio, «el desarrollo de nuevas modalidades de explotación de los recursos naturales» ${ }^{17} \mathrm{y}$ por la importancia estratégica para la economía mundial de todos ellos. En una lectura de proyección histórica del espacio africano podemos contemplar una continuidad en los procesos de construcción y destrucción de los Estados, además de «dinámicas introducidas por la colonización y continuadas en esencia por los regímenes independientes que se injertan en estos mismos procesos. A través de la mediación de la guerra y del derrumbe de los proyectos de democratización, este entrelazamiento entre dinámicas y temporalidades conduce a la salida del Estado. Impulsa el surgimiento de tecnologías de dominación basadas en formas de gobierno privado indirecto, que tienen como función la constitución de nuevos sistemas de propiedad y nuevas bases para la estratificación social» ${ }^{18}$.

De tal forma que el factor geopolítico está hoy sometido a diferentes variables. Las grandes áreas geopolíticas del continente están divididas entre la herencia colonial de la que provienen y los países metropolitanos de los que fueron colonias, y las nuevas variables derivadas de la lucha por los recursos y la incursión de potencias relativamente nuevas en el escenario africano, como son los EE. UU. y China. La situación tras la experiencia de cincuenta años de Estados independientes ha variado, pero sin solucionar muchos de los problemas reivindicados en aquel entonces. Nuevos agentes endógenos en unos casos, y exógenos en otros, han venido a convertirse en actores de primer nivel en el espacio africano ${ }^{19}$.

${ }^{16}$ Nkrumah, N., op.cit., p. 219.

17 Mrembe, A., "Al borde del mundo", en VV.AA., Estudios postcoloniales. Ensayos fundamentales, Traficantes de Sueños, Madrid, 2008, p. 183.

${ }^{18}$ Ibíd., p. 183.

19 Alden, Chris, China en África, Intermon Oxfam, Barcelona, 2008. Meredith, Matin, África. Historia de cincuenta años de independencia, Intermon Oxfam, Barcelona, 2011. 


\subsection{La cuestión de Oriente Medio}

La cuestión de Oriente Medio es hija directa del colonialismo, aunque tiene elementos derivados del conflicto árabe-israelí y, en particular, del asunto de Palestina. Ante la perspectiva de derrota del Imperio otomano en la Gran Guerra, las potencias occidentales trazaron el plan de repartición de los territorios adscritos a la Puerta. El asunto de Oriente Medio se discutió en la reunión mantenida entre Francia, representada por el diplomático Charles-George Picot, y Gran Bretaña, representada por Mark Sykes. Es el acuerdo conocido como Sykes-Picot. Franceses y británicos se repartieron la zona. En 1916 el Imperio zarista entraba en el acuerdo, pero la Revolución de 1917 lo descolgó. Dibujadas en un mapa las nuevas fronteras -igual que se hizo con el reparto de África en la Conferencia de Berlín de 1885—- el acuerdo establecía: «1.- Que Francia y Gran Bretaña están dispuestas a reconocer y proteger un Estado Árabe independiente o una Confederación de Estados Árabes en las áreas (A) y (B) marcadas en el mapa anexo, bajo el Sultanato de un jefe árabe. Que en el área (A) Francia y en el área (B) Gran Bretaña, tendrán prioridad de derechos de empresas y empréstitos locales [...]. 2.- Que en el área azul, Francia, y en la roja, Gran Bretaña, serán autorizadas para establecer toda administración o control directo o indirecto que deseen y consideren conveniente acordar con el Estado Árabe o la Confederación de Estados Árabes $»^{20}$.

El acuerdo contemplaba una serie de disposiciones de cara a favorecer las rutas comerciales que ambas potencias tenían en la zona. Gran Bretaña se quedó con los puertos de Jaifa y Acre, y garantías de provisión de agua de los ríos Tigris y Éufrates. Alejandría es declarada puerto franco para el comercio del Imperio británico, igual que Jaifa lo es para las mercaderías francesas. Las potencias se reservaron el derecho para el tránsito de tropas y material militar, para lo cual iniciaron las construcciones de los ferrocarriles que conectarían Bagdad con Mosul y Samarra — en Irak_- Bagdad con Alepo - Irak/Siria - y Bagdad con Jaifa — Irak/Palestina-. Las importaciones de armas no podrían llevarse a cabo sin el pleno consentimiento de ambas potencias, que en el punto 12 del acuerdo se reservaban el derecho exclusivo del establecimiento de las medidas para su control.

Una vez desmembrado el Imperio otomano, tras su derrota en la Gran Guerra, el Líbano y Siria entran a formar parte de los territorios coloniales adscritos a Francia. La denominación oficial será la de Mandato. Los británicos asentarán su poder directo en Transjordania, Palestina e Irak. El nuevo mapa

20 Sykes-Picot Agreement, 1916. Martínez Carreras, José Urbano, El mundo árabe e Israel: el Próximo Oriente en el siglo xx, Istmo, Madrid, 2002. SEgura I Más, Antoni, Aproximación al mundo islámico, UOC, Barcelona, 2002. 
en Oriente Próximo se verá completado después de 1948 con la proclamación del Estado de Israel, asentado en parte de la Palestina histórica. La partición de Palestina por NN. UU. será un punto caliente de la política internacional desde entonces y hasta la actualidad. Otros escenarios estarán marcados por las sucesivas guerras israelo-árabe-palestinas que tuvieron lugar en 1948, 1967, 1973, 1978, 1982 y los posteriores levantamientos populares, conocidos como intifadas palestinas.

Oriente Medio ha sido durante muchos decenios un epicentro clave de los juegos de la geopolítica internacional. Y las potencias regionales en la zona, que a su vez estuvieron influidas y condicionadas por las potencias globales, jugaron un papel importante en el área. Egipto, Irak, Siria, Jordania, Arabia Saudí, Israel e Irán son todos actores destacados del conflicto.

Egipto tuvo un Gobierno nacionalista revolucionario entre 1954 y 1970, bajo la presidencia de Nasser, y firmó un acuerdo con Siria para crear la República Árabe Unida, fórmula que se disolvió en $1961^{21}$. Nasser tuvo un papel destacado en el nacimiento del Tercer Mundo, junto con los países protagonistas de Bandung. Egipto y el nasserismo fueron pivotes claves de la política en Oriente Medio hasta la firma de los acuerdos de Camp David de 1979, en los que Egipto, bajo la presidencia de Sadat, firmó la paz por separado con Israel, bajo los auspicios de los EE. UU., poniendo fin así a la situación de guerra latente desde el conflicto armado del Yom Kipur, en 1973.

También Siria fue un país influyente en el mundo árabe de posguerra. La llegada al poder del Partido Baaz en 1963 le dio un impulso nacionalista y populista al país y lo situó en el centro de las luchas políticas de la región. Después de los acuerdos de Camp David, Siria se quedó sola frente al Estado sionista, y durante la guerra del Líbano de 1975-1989 tuvo un papel muy activo en dicho país.

La monarquía iraquí cae en 1958 tras un golpe de Estado. En 1963 sube un Gobierno nasserista, pero un nuevo golpe de Estado en 1968 coloca en el poder al Partido Baaz, de igual orientación que el sirio, pero enfrentado a él por el control hegemónico en la región. Sadam Husein desencadenará una guerra contra Irán entre 1980 y 1988, retirándose los contendientes sin que ninguno lograra una clara victoria militar. Irak había sido un país bajo la influencia occidental durante toda su existencia como Estado independiente.

Por su parte, las monarquías del Golfo y Jordania han sido de manera continuada los principales aliados árabes de los EE. UU., y son paralelamente (las monarquías del Golfo) las principales instigadoras del fundamentalismo islámico, que financian a nivel regional y global. Son muy sectarias en cuanto a la interpretación del Corán que profesan y difunden (wahabismo). Declarados enemigos de los chiitas, siendo ellos sunitas, tienen en Irán a uno de sus principales rivales. Irán es un país musulmán persa, no árabe, de creencia chiita. Irán

${ }^{21}$ Lacouture, Jean, Nasser, Dopesa, Barcelona, 1972. 
es el primer país que hizo una revolución islamista triunfante. Fue en 1979 y ello le conllevó un enfrentamiento permanente con los EE. UU. hasta la actualidad. Irán — con 80 millones de habitantes - y Egipto - con 90 millones - son los países más poblados de la zona.

Israel es uno de los países más pequeños, junto con el Líbano, pero de los más poderosos económica y militarmente, además de contar con el apoyo incondicional de los EE. UU., que no han dudado nunca en intervenir para proteger a su aliado preferencial de la zona y del globo. Israel se fundó en 1948 tras una guerra de ocupación librada contra los campesinos y pobladores palestinos, que se vieron expulsados por centenares de miles, comenzando una diáspora que llega hasta nuestros días. Los distintos gobiernos israelíes han sido frecuentemente presididos por generales bregados en las distintas guerras lanzadas contra los árabes. Entre 1948 y 1977 todos los gobiernos eran de orientación socialdemócrata (Partido Laborista). En 1977 el Likud, partido de derecha, gobierna hasta 1984. Después las alternancias se han ido sucediendo, aunque el escenario se hizo más complejo con la emergencia de nuevos partidos tras el año 2000. El conflicto que mantiene Israel en su afán de controlar todo el territorio de la antigua Palestina, y de terminar de expulsar a sus habitantes, es fuente permanente e inspiración de todas las guerras que han tenido lugar en Oriente Próximo desde 1948 hasta la actualidad ${ }^{22}$.

Finalmente Palestina. Desde la ocupación británica y tras las guerras con Israel, ha quedado reducida a una serie de territorios inconexos, sin posibilidad de convertirse en un Estado viable y castigada de manera permanente por el ejército israelí o las milicias paramilitares de los colonos, en su empeño constante de arrebatar las tierras a los pobladores palestinos. Tras la guerra de 1948 los palestinos se asentaron en campos de refugiados en los países ribereños. Jordania y el Líbano fueron destino de centenares de miles de palestinos. Ambos países eran pequeños y de poca población, de tal modo que la llegada masiva de refugiados cambió los equilibrios internos en los dos países. Con la guerra de los Seis Días (junio de 1967) se volvió a reproducir el mismo fenómeno, pero ahora (1964) los palestinos habían creado la OLP (Organización para la Liberación de Palestina), agrupamientos de organizaciones políticas dispuestas a luchar militarmente contra los sionistas. Entre 1970 y 1973 las tensiones en Jordania y el Líbano crecieron. Los palestinos se habían hecho fuertes en esos dos países, de débiles estructuras estatales y pequeños ejércitos; en el caso libanés, dividido por las disputas étnico-religiosas endógenas. De tal modo que cuando comenzó la guerra civil en el Líbano (1975), los palestinos eran una fracción más en la contienda, a la que se sumaron también sirios e israelíes.

22 Shlaim, Avi, El muro de hierro. Israel y el mundo árabe, Almed, Granada, 2011. PAppé, Ilan, La limpieza étnica de Palestina, Crítica, Barcelona, 2008. 
Tras la guerra del 67 Israel terminó de ocupar toda la tierra palestina, y aunque hubo un mandato de NN. UU. para que se retirasen a las posiciones anteriores a la guerra, los gobiernos de Tel Aviv no se avinieron a aceptar la resolución 242 de 1967. Con su participación en la guerra del Líbano, Israel ocupó el sur de ese país desde 1978 y Beirut desde 1982. El cerco militar y un intenso bombardeo a los que sometió a esa ciudad causaron 18.000 muertos, 20.000 heridos y 30.000 desplazados. Las bajas israelíes ascendieron a 318 muertes, 2.000 heridos, cinco desaparecidos y 11 prisioneros. Los enfrentamientos con palestinos y libaneses han continuado hasta la actualidad, y en las décadas iniciales del siglo xxi las guerras, ocupaciones y asesinatos recurrentes son moneda común de la relación de Israel con sus vecinos, lo cual cosecha respuestas de variada violencia, casi siempre de baja intensidad, que la prensa occidental publicita como actos terroristas. La desigual fuerza disponible para cada uno de los bandos opera en beneficio permanente del Estado de Israel, que goza de una superioridad abismal frente a las guerrillas irregulares de los palestinos y a la del partido-milicia Hezbolá en el Líbano. Este hecho quedó de manifiesto en la guerra de 2006 que libraron Israel y Hezbolá23.

El mundo árabe ha continuado agitado en las décadas de comienzo del siglo xxi. El proceso denominado de las primaveras árabes, iniciado en 2011 en Túnez, contagió a varios países, entre ellos Egipto, que vio cómo caía la autocracia gobernante en el país para reinstalar de nuevo, por medio de un golpe militar, una dictadura que truncó el proceso democrático. Libia se vio sacudida por una guerra civil y su dirigente, Gadafi, ajusticiado, para a continuación descarrilar como Estado y ser incapaz de volver a restituir una autoridad central. La "primavera» se extendió por los países del Golfo, pero fue militarmente frenada. Sin embargo, a Siria la sumió en una guerra civil que la ha dejado destruida y dividida. En Irak, la guerra y ocupación norteamericana iniciada en 2003 ha dejado un conflicto abierto. En su territorio, igual que en Siria, existen amplias franjas controladas por las milicias de ISIS, nuevo actor político, heredero de Al Qaeda, pero que ha logrado una base territorial amplia de la que carecía su antecesor. El Califato Islámico impugna de hecho la distribución territorial acordada entre franceses e ingleses en 1916 y reordena territorialmente Oriente Medio. Al mismo tiempo se produce la emergencia y consolidación militar de los kurdos sirios e iraquíes, que también asoman como nuevos actores estratégicos en la contienda contemporánea de todo Oriente $\mathrm{Medio}^{24}$.

${ }^{23}$ Achcar, Gilbert y Warschawski, Michel, La guerra de los 33 días. Israel contra Hezbolá, Icaria, Barcelona, 2007.

${ }^{24}$ Bozarslan, Hamit, Una historia de la violencia en Oriente Medio: Desde el fin del Imperio otomano Al Qaeda, Península, Barcelona, 2009. FIsk, Robert, La gran guerra por la civilización. La conquista de Oriente Próximo, Destino, Barcelona, 2006. 


\section{DINÁMICAS SOCIOPOLÍTICAS EN EL NORTE Y EL SUR: 1950-1980}



4.1. LuCHAS DE LIBERACión NACIONAL y GUERRAS CAMPESINAS EN CENTROAMÉRICA y EL Caribe

Todo el subcontinente americano ha visto su soberanía cortocircuitada por las injerencias de la potencia norteamericana a lo largo del siglo xx. Distintas corrientes políticas trataron de dar respuesta a esta situación y para ello formularon propuestas teóricas y políticas que pudiesen ayudarlas. El desarrollo del populismo en los grandes países del sur americano en la primera mitad del siglo son prueba de ello. Tanto Argentina como Brasil vivieron intensos episodios bajo la batuta de gobernantes populistas, que en sus comienzos desarrollaron políticas de contenido popular.

En el plano de las propuestas teóricas, y de interpretación de la realidad latinoamericana, fue central la denominada Teoría de la Dependencia. Con ella se pretendía dar explicación al atraso de los países latinos y a su rol en el mundo periférico. Tal teoría agrupó a un nutrido grupo de intelectuales, algunos de fuera de Latinoamérica, que dieron cuerpo con sus investigaciones a ese modelo de interpretación.

Se suele convenir en que fue Raul Prebisch, economista de la CEPAL (Comisión Económica para América Latina), quien en 1949 usó por primera vez el concepto de Teoría de la Dependencia, con el que trató de explicar la realidad de Latinoamérica alejándose del enfoque clásico y neoclásico de los economistas de los países del centro. Para Prebisch la economía mundial divide al mundo en países del centro y países de la periferia. Es decir, países centrales, con fuerte desarrollo industrial, y países periféricos, de débil desarrollo industrial y especializados en la economía agraria de exportación. También ha sido denominado este modelo como el de centro-periferia.

Esta teoría refuta la tesis de los economistas neoclásicos, que explicaban el atraso latinoamericano en términos etapistas: para ellos, tal atraso era un momento del camino al desarrollo. Prebisch vino a señalar que el subdesarrollo era producido por el desarrollo de los países centrales y que la periferia era condición necesaria del desarrollo del centro. La estructura de la economía mundial adjudicaba roles a los países y continentes; unos producirían bienes manufacturados de alto valor añadido, y otros, productos agrícolas y materias primas para el mercado mundial de bajo valor añadido. 
El subdesarrollo de unos era en consecuencia necesario para el desarrollo de otros. Tras esta primera aportación de Prebisch, otros autores se sumaron con sus estudios a esta tesis de interpretación de la realidad latinoamericana. Entre los más destacados encontramos a André Gunder Frank, Theotonio Dos Santos, Celso Furtado, Samir Amín ${ }^{1}$ (Egipto) y otros muchos por los cinco continentes. Los teóricos de la dependencia incorporaron enfoques desde diversos campos de estudios y de distintas tradiciones intelectuales como el neomarxismo y neokeynesianismo.

Estos estudios ayudaron a impulsar las luchas en todo el subcontinente americano, dándoles un marco teórico sólido. Posteriormente se usaron para desarrollar estrategias nacionales de desarrollo económico y político que combatían la dependencia y el intrusismo de los EE. UU. En el caso de los países centroamericanos, así como en Cuba, el auge de las guerrillas estuvo acompañado por este tipo de explicaciones.

Fue en Cuba donde las revueltas llegaron más lejos, más pronto. Los cubanos ya se habían mostrado muy beligerantes y celosos de su independencia en la guerra contra España, que concluyó en 1898 con la independencia de la Isla, aunque los norteamericanos la frustraron en parte interviniendo en ella y condicionando el estatus de país independiente por medio del Tratado de París, firmado entre España y los EE. UU. con ausencia de los cubanos. La intromisión de los EE. UU. se plasmó legalmente con la introducción en la Constitución cubana de una enmienda conocida como Enmienda Platt, por ser el nombre del senador estadounidense que la redactó, y en la que se decía: «El Gobierno de Cuba consiente en que el de los Estados Unidos pueda ejercer el derecho de intervenir para la preservación de la independencia cubana, el mantenimiento de un gobierno adecuado para la protección de la vida, la propiedad y la libertad individual y para el cumplimiento de las obligaciones con respecto a Cuba, impuestas por el Tratado de París a los Estados Unidos y que ahora debe asumir y cumplir el Gobierno de Cuba». La injerencia norteamericana en la Isla fue constante desde entonces, aunque el sentimiento nacionalista en Cuba nunca desapareció, y esas políticas injerencistas estuvieron recurrentemente impugnadas por los agentes más activos de la sociedad isleña.

La simulación democrática puesta en marcha por el general Machado en 1928 fue constantemente contestada por los estudiantes universitarios y los trabajadores de las distintas ramas productivas. Intentos reformistas, producto de las luchas sociales de comienzo de los treinta, se frustran con un nuevo Gobierno pronorteamericano, bajo el mandato del general Batista. Carlos Mendieta asumió

${ }^{1}$ SAntos, Theotonio Dos, «La teoría de la dependencia: un balance histórico y teórico", en Los retos de la globalización. Ensayo en homenaje a Theotonio Dos Santos. LóPEZ Segrera, Francisco (ed.), UNESCO, Caracas, Venezuela, 1998. 
el poder en 1934, con el apoyo de EE. UU. No obstante, como consecuencia de las revueltas se lograron algunos avances importantes, entre los que se destaca la derogación de la Enmienda Platt, quedando como resultado de esto la base norteamericana en Guantánamo, la autonomía universitaria, la reducción de la jornada laboral a ocho horas, así como el avance de la conciencia nacionalista y antiimperialista.

La situación de conflicto perduró en las décadas siguientes. En 1952 Batista da un golpe de Estado para hacerse con todo el poder. El golpe encontrará pronto la respuesta del Movimiento 26 de Julio. Tal día de 1953, y de ahí su nombre, un grupo de guerrilleros asalta el cuartel Moncada, en Santiago de Cuba. El asalto fracasó y sus líderes fueron arrestados unos días después, incluido Fidel Castro. Llevado a juicio, es condenado a quince años; pero, sin embargo, Batista lo indulta y lo expulsa del país dos años después para intentar aflojar la presión de la calle en favor de los considerados héroes del Moncada.

Exiliado en México, organiza la entrada en la Isla en 1956, junto con un puñado de revolucionarios, entre los que están el Che Guevara, Raúl Castro, Camilo Cienfuegos, Juan Almeida, Francisco Medina y otros. Con la llegada del Granma a la Isla se inicia la guerrilla, cuya base central se ubicará en la Sierra Maestra, en el oriente de Cuba. Después de tres años de lucha guerrillera, las columnas de los insurgentes entran en La Habana de manera triunfal el 1 de enero de 1959. Los revolucionarios cubanos habían obtenido una victoria militar frente al ejército regular de Batista, al cual apoyaban los EE. UU. Por primera vez en Latinoamérica una revolución triunfaba, incluso contra el parecer del poderoso vecino del norte. La Revolución cubana originariamente era de componente nacionalista y antiimperialista, y no adquirió su carácter socialista hasta abril de 1961, dos años después de la toma del poder y en un contexto de agresiones y sabotajes continuados, organizados por la CIA. De esta manera la Revolución buscaba apoyo en la URSS, como una forma de poder enfrentar los intentos desestabilizadores organizados por los gobiernos de EE. UU., que en ese instante ejecutaba una incursión a la Isla con el desembarco en Playa Girón. Abortada por el ejército revolucionario, este fracaso supuso un duro revés para la esperanza de la contrarrevolución de terminar en breve con la experiencia castrista.

Los norteamericanos decretaron entonces un bloqueo económico contra la Isla que sigue vigente. En 1962 la URSS instaló misiles nucleares en la Isla, lo que generó un nivel de tensión muy alto con el Gobierno de Kennedy. Los soviéticos terminaron retirando los misiles dos semanas después, pero habían dejado claro que iban a ser un apoyo firme al Gobierno revolucionario de Cuba.

El poder revolucionario afrontó rápidamente medidas urgentes, entre las que cabe destacar una importante reforma agraria y expropiación y nacionalización de actividades de importancia estratégica. A la vez, puso en marcha un ambicioso plan para erradicar el analfabetismo y una reforma en profundidad de todo el sistema educativo, haciéndolo accesible al conjunto de la ciudadanía. Se impulsaron planes de alfabetización de adultos y obreros analfabetos. También 
se tomaron medidas para reformar la asistencia y atención sanitaria, a la que se dio carácter universal y gratuito, igual que a la educación ${ }^{2}$.

Cuba se había convertido en el primer país socialista de América y ello le iba a acarrear muchos problemas en el terreno diplomático y económico con los EE.UU. y sus aliados, pero a la vez se convertiría en el referente de las luchas obreras, campesinas, estudiantiles e indígenas de toda Latinoamérica. El papel de Cuba en algunos episodios de las luchas en Centroamérica fue importante. En El Salvador, Nicaragua o Guatemala, así como en México, la Revolución cubana inspiró, y apoyó en lo que pudo, las experiencias antiimperialistas que surgieron.

En África apoyó al Gobierno de Angola cuando el país fue invadido por la racista República Sudafricana. Cuba envió decenas de miles de tropas a defender la Revolución angoleña. Los soldados cubanos ganaron batallas decisivas desde que llegaron al país africano en 1975, y su acción fue clave en el debilitamiento y posterior caía del régimen racista sudafricano en 1991. En ese año los cubanos se retiraron definitivamente de Angola. Además de soldados, Cuba envió miles de médicos, ingenieros y maestros que apoyaron la construcción de una base necesaria de organizaciones civiles, que sostuvieron al Gobierno de Luanda ${ }^{3}$.

La experiencia cubana insufló ánimos en los países de América Central y del Sur. Las teorías del foquismo del Che Guevara jugaron un papel importante para que ello fuese así. Guevara opinaba que desde un foco revolucionario insertado y consolidado en el país, a semejanza de lo ocurrido en Cuba, se podía tomar el poder por medio de la revolución armada. El foco revolucionario original se extendería entre las masas campesinas y se podrían cercar las ciudades, contando con el apoyo de los revolucionarios en el interior de las urbes. La teoría pretendía extender el foquismo por toda Latinoamérica y el Tercer Mundo, creando «muchos Vietnam».

El Che emprende un recorrido por varios países de África y no encuentra condiciones para poner en práctica el foquismo. Retorna a Cuba, sin funciones ya en el Gobierno, y decide comenzar un foco en Bolivia. Rodeado de un grupo de guerrilleros, termina pereciendo producto de una emboscada, coordinada entre los rangers norteamericanos y el ejército boliviano ${ }^{4}$.

Los seguidores guevaristas se extendieron por todo el subcontinente y el mundo. Las realidades sociales en la mayoría de los países latinoamericanos facilitaban la propagación de las teorías del Che. En los países centroamericanos los campesinos eran explotados con dureza por la oligarquía local y las compañías

${ }^{2}$ García Regueiro, Ovidio, Cuba. Raíces y frutos de una revolución, IEPAL, Madrid, 1970.

${ }^{3}$ Domínguez, Jorge, La política exterior de Cuba: (1962-2009), Colibrí, Madrid, 2009.

${ }^{4}$ Massari, Roberto, Che Guevara: grandeza y riesgo de la utopia, Txalaparta, Tafalla, 1997. 
multinacionales, en especial la United Fruit norteamericana, la gran exportadora de la fruta producida en la región.

El ejemplo más paradigmático a este nivel fue Nicaragua, donde una guerrilla tomó el poder en 1979, convirtiéndose de esta manera en el segundo país latinoamericano en hacer una revolución. Nicaragua había estado intervenida históricamente por los EE. UU. y su proclamación como país independiente en 1821 no había servido para el progreso de las mayorías sociales. En las primeras décadas del siglo xx un ejército liberal se opone a las injerencias de los EE. UU. Entonces se produce un desembarco de los marines, que entablaron batalla contra los rebeldes por el control del país. Cuando los norteamericanos se retiraron (1933) dejaron en el poder al dictador Anastasio Somoza, reforzado por la recién fundada Guardia Nacional, cuerpo creado por los norteamericanos.

Somoza asesina sin demora al jefe del ejército liberal revolucionario, $\mathrm{Au}-$ gusto César Sandino. Las políticas del somocismo supusieron un aumento del latifundismo, cuyo mayor exponente fue el propio Somoza. Él y su familia se trasmutan en agentes económicos claves de Nicaragua. Primeros productores de café y algodón del país, construyeron un puerto exclusivo para la exportación de sus productos. El nepotismo y la corrupción de la dictadura sirvieron a los intereses norteamericanos, los cuales se vieron recompensados al otorgárseles el comercio del caucho, las minas de oro, la producción de cemento y otras lucrativas actividades.

En estas condiciones se articula en torno a la figura de Carlos Fonseca una oposición antisomocista, que decide emprender el camino de la lucha armada contra la dictadura. Se recupera simbólicamente la figura de Sandino y se proclama el componente antiimperialista del movimiento. La guerrilla se va extendiendo por el país, incorporándose a ella la militancia procedente del campesinado y de los sectores urbanos de los movimientos sociales. El objetivo es llevar a cabo una reforma agraria cuando caiga Somoza.

El caos ocasionado por el terremoto que asoló el país en 1972 y la inacción del Gobierno para solucionar los problemas generados por el seísmo ampliaron las simpatías hacia la guerrilla en todo el país. El Frente Sandinista de Liberación Nacional fue liberando partes del territorio partiendo de la región de las Segovias, que era donde tenía una base social más amplia. Ante el aumento de las acciones guerrilleras y el ascenso de la protesta, la represión creció en intensidad a lo largo de la década y, en 1979, el Gobierno cae, haciéndose el FSLN con el poder. El 19 de julio se toma Managua. La guerra había dejado 50.000 muertos y cuantiosas pérdidas económicas ${ }^{5}$.

5 «Nicaragua debe sobrevivir». Documento elaborado por brigadistas internacionales de Tenerife, que habían estado trabajando en aquel país en las áreas de sanidad, educación y agricultura. 1986. 
El país tuvo luego que enfrentarse a una guerra auspiciada por los EE. UU. que duró toda la década siguiente, desde la llegada al poder de Reagan en 1981. La Administración conservadora organizó y financió a la contra nicaragüense, intervino directamente bombardeando los puertos del país y bloqueó su economía. Los neoconservadores querían que no se repitiese una historia como la de Cuba ni que se instalase en Centroamérica un Gobierno izquierdista que luego pudiese irradiar su acción en los países vecinos.

Las guerrillas estaban entonces extendidas por toda la región centroamericana, y el malestar social y político era evidente en países como Guatemala, donde ya se había intentado un Gobierno nacionalista a principios de la década de los cincuenta. En 1944 una rebelión social puso fin a la dictadura de Ubico e impulsó un Gobierno tímidamente nacionalista, que tenía un programa para la reforma bancaria y del petróleo, así como del sector agroexportador. Estas leyes afectaban a las empresas de los EE. UU., que dominaban ambos sectores. Igualmente, se llevó a cabo una campaña de alfabetización y de autonomía universitaria. Estas medidas inquietaron a los sectores de la oligarquía nacional, que trataron de dar un golpe de Estado en 1949 para revertir la situación, pero los obreros y los campesinos armados lo impidieron.

En 1952 Jacobo Arbens ganó las elecciones y continuó las medidas de reformas impulsadas por los gobiernos anteriores, a los que él mismo pertenecía. Arbens trató de impulsar una profunda reforma agraria, nacionalizando tierras e introduciendo nueva tecnología en su explotación para apoyar a los campesinos pobres y organizar una agricultura capitalista. Las nacionalizaciones afectaron a las grandes propiedades improductivas, lo cual tocaba los intereses de la United Fruit, que poseía grandes propiedades improductivas. Igualmente, un plan de carreteras en dirección al Atlántico despojaba a la compañía norteamericana IRCA (International Railways of Central America) del control del transporte. La proyección de una central hidroeléctrica quitaba el monopolio de la energía a la Bond and share Company ${ }^{6}$. El resultado de todas esas medidas fue la organización y ejecución de un golpe de Estado auspiciado por la CIA, que puso en el Gobierno al general Castillo Armas. Foster Dulles, secretario de Estado de los EE. UU. y accionista de la United Fruit, dijo en la Declaración de solidaridad para la preservación contra el comunismo internacional que el objetivo de su país era la proscripción de «toda la actividad comunista» en el continente. Guatemala se sumió desde entonces en un largo ciclo de políticas represivas durante las décadas siguientes. Matanzas indiscriminadas de campesinos e indígenas fueron piedra común hasta el final de la guerra fría.

${ }^{6}$ Martínez Díaz, Nelson, «Iberoamérica en la encrucijada», en Historia 16, Historia Universal 23, 1983, pp. 7-55. 
Por su parte, en El Salvador se produjo una intensificación de la guerra campesina a finales de la década de los setenta. Ante tal situación, los norteamericanos manifestaron que «los Estados Unidos no van a permitir un triunfo militar de la guerrilla en El Salvador; tienen los medios y la voluntad de hacerlo, sin que importe el coste político» ${ }^{7}$. Tal sentencia la había manifestado el subsecretario de Estado norteamericano para Asuntos Latinoamericanos. La política radical de beligerancia extrema contra los procesos revolucionarios en el continente va a ser una constante de la década. Los norteamericanos justificaban esta actitud en la supuesta injerencia soviético-cubana en la zona, que EE. UU. pretendía haber demostrado - nunca quedó claro el asunto- con la edición de un Libro Blanco que fue repartido en las cancillerías occidentales en aquel entonces.

La guerrilla salvadoreña se había agrupado en el Frente Farabundo Martí para la Liberación Nacional (FMLN), y era el resultado de un acuerdo alcanzado por distintos sectores de la oposición social y política. La guerrilla logró sólidas bases de apoyo social en el norte y centro del país, estableciendo en ellas zonas liberadas bajo su control. Militarmente se estableció un empate técnico, entendido en el sentido de que el FMLN fue consciente desde mitad de la década de que no podría derrocar al Gobierno, y este, a la vez, también asumió el hecho de no poder derrotar a la guerrilla, a pesar del sólido apoyo que le brindaba la Administración norteamericana en dinero, armas y asesoramiento militar.

El Gobierno usó a los paramilitares para castigar a la población y a los sectores que consideraba cercanos a la guerrilla. Los llamados «escuadrones de la muerte» ejecutaban de manera extrajudicial a las víctimas escogidas. Algunos asesinatos tuvieron mucha resonancia internacional, dado que las víctimas habían sido, en algún caso, personas de relevancia social, como fue monseñor Romero, arzobispo de San Salvador, asesinado en marzo de 1980 por los escuadrones de la muerte mientras impartía una misa. Monseñor Romero era un activo defensor de los derechos humanos. En otra ocasión (noviembre de 1989), seis jesuitas y dos mujeres fueron asesinados por los escuadrones en el campus de la Universidad Centroamericana de El Salvador.

La protesta obrera y social había sido un factor clave entre 1975 y 1980 para el nacimiento de la guerrilla. Y la agudización de la guerra sostuvo y amplió el movimiento social, a pesar de que este había sido duramente castigado por la represión. Entre 1982 y 1985 fueron asesinados 25.000 obreros y campesinos por su actividad sindical ${ }^{8}$. «El anticomunismo fanático del ejército; la endeblez, el compadrazgo y el servilismo del poder judicial para con los militares y cuerpos

7 «América Central en el eje del huracán», en América Latina y África. Revista del Tercer Mundo, n. ${ }^{\circ}$ 7, septiembre de 1981, p. 56.

${ }^{8}$ Perales, Iosu, El volcán en guerra. El Salvador 1979-1987, Ed. Revolución, Madrid, 1988. 
de policía; la acción continuada de los Escuadrones de la Muerte que siguen actuando a un ritmo de 40 atentados por mes; y la propia acción militar que se ha cobrado durante estos tres últimos años un promedio anual de entre $1.500 \mathrm{y}$ 2.000 víctimas mortales entre los civiles, ponen en evidencia la debilidad extrema del régimen salvadoreño» ${ }^{9}$.

Al final de la guerra fría se entablaron conversaciones de paz, auspiciadas y controladas por la ONU. Se creó la «Comisión de la Verdad», que debía investigar y depurar responsabilidades tras los doce años de guerra civil. Sin embargo, los antiguos jefes de los escuadrones de la muerte desempeñaron el poder civil tras el final de la guerra en el país y de la guerra fría, agrupados en el partido ARENA (Alianza Republicana Nacionalista). La situación en El Salvador ha ido degradándose en las últimas décadas, más allá de las negociaciones de paz. Las políticas neoliberales han sido aplicadas con celosa intensidad y, lo mismo que ha ocurrido en los países de la zona, las desigualdades enormes y la gran concentración de la riqueza en pocas manos generan una sociedad desestructurada y violenta ${ }^{10}$.

Por su parte, el conflicto armado de Colombia se ha mostrado como el de mayor complejidad de cara a su resolución. La existencia de varias guerrillas, las organizaciones del narcotráfico y de los paramilitares, así como el ejercito nacional, han trazado un mapa altamente complejo para una salida definitiva a esa situación. Tras varios intentos negociadores no se ha logrado un acuerdo final, que sin embargo parece cada vez mas próximo ${ }^{11}$.

\subsection{Los NUEvos MOVIMIENTOS SOCIALES: PACIFISMO, ECOLOGISMO, FEMINISMO}

Durante la década de los sesenta e influidos por las guerras de liberación nacional en el Tercer Mundo, y de manera particular por la guerra de Vietnam, emergieron nuevos movimientos sociales en multitud de países y, en especial, en los del primer mundo. El agotamiento del modelo democrático, la pérdida de legitimación de las instituciones históricas, así como el ascenso de una cultura antiautoritaria, ayudaron a desarrollar la protesta, canalizada sobre todo en torno a estos tres movimientos sociales, a los que habría que sumar el movimiento por los derechos civiles para la población negra en los EE. UU. y el siempre presente movimiento obrero sindicado, y en algunos casos el emergente y crítico con el sindicalismo tradicional.

${ }^{9}$ Ibíd., p. 20.

${ }^{10}$ Krujt, Dirk, Guerrilleros. Guerra y paz en América Central, Icaria, Barcelona, 2009.

11 Gutiérrez Sanín, Francisco, Wills Obregón, María Emmma y Sánchez Gómez, Gonzalo (coords.), Nuestra guerra sin nombre: transformaciones del conflicto en Colombia, Norma, Bogotá, 2006. 
El inicio del ciclo de protestas estuvo muy relacionado con la invasión norteamericana de Vietnam, a la que se opusieron incluso países amigos, como fue el caso del Gobierno del presidente francés De Gaulle, que en disconformidad con la guerra retiró a Francia de la OTAN en 1966. La presencia norteamericana era ya patente incluso cuando la zona estaba bajo dominio francés después de la Segunda Guerra Mundial. Con la retirada francesa por la derrota de Dien Bien Phu y la firma de los acuerdos de Ginebra en 1954, los EE. UU. ocuparon la posición de potencia hegemónica en la región. Auparon a un Gobierno títere en Vietnam del Sur en 1955 e impidieron la unificación del país por temor a que los comunistas del norte establecieran su influencia también en el sur. La guerra aumentó su intensidad en la década siguiente. Desde 1965 podemos considerar que se inicia la guerra de carácter «convencional» con la intervención de los norteamericanos bombardeando las posiciones del norte.

La escalada fue en aumento en los años sucesivos, y los especialistas consideran el año 1968 como el momento clave del conflicto; a partir de ahí los EE. UU. comenzaron a perder la guerra. La aventura militar estadounidense estaba siendo vivida con inquietud en la Bolsa neoyorquina, porque generaba inflación en la economía y aumento del déficit, desestabilizando el sistema monetario internacional tal cual había sido diseñado en Bretton Woods, anclando el dólar al oro y haciendo que la moneda norteamericana se usase en el comercio y las transacciones internacionales. Tal es así que Nixon abandonó en 1971 el patrón oro debido a estos problemas señalados. Paralelamente, la sociedad civil comenzó a mostrar su desacuerdo con la guerra. Sin embargo, la intensificación del conflicto continuaba. Centenares de miles de norteamericanos estaban desplegados en el país asiático, y los bombardeos de la aviación producían estragos sobre la sociedad civil vietnamita, sus cosechas y su medio ecológico, porque las bombas iban cargadas de agentes químicos. Los estadounidenses querían de esta manera despoblar los campos, para que los campesinos no sirviesen de apoyo logístico a los guerrilleros vietnamitas. No obstante, el aumento de los bombardeos no debilitó la posición del FNL (Frente Nacional de Liberación).

El 31 de enero de 1968 el FNL lanzó la ofensiva del Tet, que consistió en un ataque simultáneo a un centenar de ciudades de Vietnam del Sur, las cuales estaban bajo control del ejército de los EE. UU. En ese momento el número de soldados norteamericanos ascendía a 550.000, pero esta ofensiva puso de manifiesto, a pesar de las grandes pérdidas en vidas para los vietnamitas, la voluntad de ganar la guerra y la imposibilidad del triunfo para los estadounidenses. Después de esta ofensiva los norteamericanos estudiaron la posibilidad de retirarse de Vietnam. Comenzaron a celebrarse encuentros para negociar los términos del final de la guerra. En la Conferencia de París de mayo de 1968 fue la primera ocasión.

La guerra había estado dirigida por el presidente demócrata Johnson, quien había ascendido a la presidencia por primera vez tras el asesinato de Kennedy en 1963, del cual era vicepresidente. Ganó las presidenciales en noviembre de 
1964, revalidando cuatro años más su mandato. Los republicanos ganaron las elecciones en 1968 e hicieron presidente a Nixon.

A lo largo de 1969, y mientras arreciaba la protesta antiguerra en los EE. UU., la Casa Blanca comienza a negociar su retirada, que no obstante se retrasaría unos cuantos años. Pero la Administración Nixon sabe que no podrá ganar la guerra, y solo espera el mejor momento para anunciar el repliegue. En 1969 informó de que se haría una retirada por etapas y de manera ordenada, aunque eso no implicaba el fin de las hostilidades; de hecho, los EE. UU. siguieron con los bombardeos hasta el verano de 1973. La paz definitiva se logró en abril de $1975^{12}$.

El ascenso del movimiento antiguerra fue clave para que se desarrollara el movimiento pacifista, y su influjo abarcará el mundo en las décadas siguientes. La guerra de Vietnam originó en los EE. UU. una potente oposición en las universidades, agrupada por medio de las asociaciones de estudiantes. Mostró su rechazo al militarismo y al imperialismo y se solidarizó con las víctimas de ambos bandos. También el mundo de la cultura y del deporte se sumó a este movimiento. Los veteranos de Vietnam jugaron un papel muy positivo denunciando la guerra y sus atrocidades, y los afroamericanos, que tenían por su parte una lucha en defensa de los derechos civiles, aportaron nuevas razones a la protesta. Los hippies y el mundo contracultural hicieron lo propio y rechazaron también la guerra. Las energías se canalizaron por vía de manifestaciones masivas, grandes conciertos de música, resistencias al reclutamiento (quema de cartillas militares) y, en algunos casos, manifestaciones con graves enfrentamientos con la policía.

El pacifismo evolucionó hacia la crítica al rearme nuclear. Si la década de los setenta, sobre todo su segundo quinquenio, estuvo marcada por la derrota norteamericana en Vietnam, el ascenso de Reagan supuso una vuelta al militarismo duro. En esta ocasión la dinámica armamentística se centró en el impulso y desarrollo de las armas nucleares. El despliegue de misiles de medio alcance (Pershing y Cruise) en Europa occidental (Gran Bretaña, Alemania, Bélgica, Italia y Holanda) desafía los misiles SS-20 soviéticos desplegados en la Europa oriental.

La evolución de la carrera de armamentos había llevado a las dos potencias a firmar una serie de tratados para el control de la fabricación y despliegue, al punto de garantizar lo que la doctrina llamó la Destrucción Mutua Asegurada, o equilibrio del terror. Este era el sentido de los Acuerdos SALT i (Strategic Arms Limitation Talks) firmados en 1972. Pero en 1979 los EE. UU. no firmaron el acuerdo SALT II, que pretendía limitar el número y tipo de misiles intercontinentales. Tal negativa aceleró la carrera de armamentos en la década siguiente, cuando la Administración Reagan impulsó la Iniciativa de Defensa Estratégica,

${ }^{12}$ Neale, Jonathan, La otra historia de la guerra de Vietnam, El Viejo Topo, Madrid, 2003. Devillers, Philippe, De Indochina a Vietnam, Historia 16, 1985. 
conocida en la prensa como guerra de las galaxias. En consecuencia, el movimiento pacifista tuvo que centrar su acción en la crítica y la protesta contra la proliferación nuclear. Sobre todo en Alemania esta historia fue crucial, y conllevó la ruptura del Gobierno socialdemocrócrata-liberal, por el rechazo de muchos diputados del SPD al despliegue de los misiles en suelo de la RFA. También en Gran Bretaña hubo una oposición constante al despliegue de los misiles en la Isla.

La relativa distensión del periodo 1972-1979 dio paso a una nueva carrera de armamentos y a una subida de la tensión entre 1979 y 1989. La llegada al poder de Reagan supuso un intervencionismo militar directo o encubierto en los países periféricos (Nicaragua, El Salvador, Honduras, Guatemala, Angola, Afganistán, Camboya, Granada y Libia) y un aumento considerable en los gastos militares. La IDE significó el fin de la doctrina DMA (Destrucción Mutua Asegurada).

El ecologismo se desarrolló en paralelo a este movimiento, dado que comportaba como una de sus señas de identidad la crítica al uso civil del átomo. La catástrofe de Chernobyl en 1986 vino a reforzar sus tesis. La explosión de la central soviética en Ucrania fue un serio aviso al hecho de que lo nuclear comporta muchos más riesgos que beneficios. El ecologismo, que ya había dado señales sólidas de emergencia con su crítica a la sociedad productivista, vendría para quedarse y convertirse con el tiempo en un movimiento de larga duración. $\mathrm{Su}$ agenda fue posteriormente incorporada por las instituciones mundiales y los gobiernos nacionales en la mayoría de países industriales.

Desde 1972 el informe del Club de Roma advirtió sobre los límites del crecimiento y los problemas medioambientales que traía aparejado el modelo productivista. Economistas de ascendencia neomarxista señalaron que la crisis industrial traía consigo una crisis de modelo civilizatorio.

La preocupación medioambiental hundía sus raíces en el siglo xix, aunque lo hacía de manera marginal en entornos de crítica vanguardista, entre poetas y aristócratas. Luego se sumaron obreros que defendían su salud. La defensa del medioambiente nació asociada a la preocupación por la degradación del paisaje que producía el desarrollo industrial. Más tarde, las aglomeraciones barriales en las que se hacinaban los obreros emigrados de la primera y la segunda revolución industrial obligaron a propulsar medidas de higiene, y los poderes públicos tuvieron que tomar medidas en ese sentido.

El asunto fue menor hasta bien avanzado el siglo xx, en que comenzaron a darse señales de evidentes cambios producidos por el sistema industrial sobre el medio terrestre, marino y atmosférico. El ecologismo que nació en torno a la década de los sesenta hacía frente a una amenaza de carácter global. El modelo fordista de producción, la sociedad de consumo masivo y las armas atómicas hicieron que los problemas ambientales se convirtiesen en asuntos globales. No había frontera política que pudiese parar los efectos generados por esa tríada de desafíos. En ese momento aparecieron los informes del Club de Roma titulados Los límites del crecimiento (1972) y La humanidad en la encrucijada (1974). Dichos 
informes fueron posteriores a la Conferencia Internacional de la Biosfera celebrada en París en $1968^{13}$.

El movimiento ecologista estuvo precedido por estudios científicos que alertaban sobre la degradación medioambiental. Y su acción ha ido acompañada desde entonces por las advertencias que la comunidad científica ha venido realizando. El movimiento ecologista se basó en la máxima de «pensar globalmente y actuar localmente», y ha mantenido una relación muy estrecha entre científicos, activistas, movimientos indígenas y, finalmente, partidos políticos que se adscribieron al movimiento verde. No es casualidad que Greenpeace se fundase en el año 1971 ni que su nacimiento, que se produjo en Canadá, fuese el resultado de protestas y desacuerdos contra los ensayos nucleares.

La historia del movimiento ecologista en cada país tiene un origen diferenciado y unas causas propias debido a que la toma de conciencia ambiental se produce en el choque con la realidad inmediata. En algunos países europeos, particularmente Alemania, el movimiento dio de manera temprana el salto a la política con cierto éxito. Los Verdes fueron los representantes políticos de lo que se denominaban los nuevos movimientos sociales (pacifismo, ecologismo, feminismo). No sin tensos debates en su seno, decidió entrar en política en 1980. Muchos de sus integrantes mostraron su desacuerdo con tal estrategia porque entendían que convertirse en un partido político parlamentario desvirtuaba el sentido original de su propuesta, que era la de ser un referente de la antipolítica ${ }^{14}$.

Lograron entrar por primera vez en el Bundestag en 1983, rebasando el $5 \%$, y abrieron de esta manera un nuevo espacio de trabajo político, que hasta entonces el movimiento ecologista no había tenido en cuenta, o lo había hecho con cierto desprecio hacia esas instancias institucionales.

La importancia de la temática medioambental llegó a los organismos internacionales y desde principios de los setenta se creó la dinámica de celebrar cumbres climáticas en las que se analizaba la evolución del problema y se proponían medidas para que los Estados actuasen en consecuencia. Más de una veintena se han celebrado hasta 2015, siendo las de mayor transcendencia las organizadas en Río de Janeiro (1992), Kioto (1997) y Copenhague (2009).

Por su parte, el movimiento feminista de los años sesenta y posteriores amplió de manera importante el alcance y contenido del feminismo de principios del siglo xx. La teoría feminista, igual que lo había hecho la ecologista, cambió la percepción de los problemas en la sociedad contemporánea. El feminismo de esa época atravesó diferentes etapas, marcadas a su vez por los distintos contenidos de sus propuestas.

13 Reichmann, Jorge y Fernández Buey, Francisco, Redes que dan libertad, Planeta, Barcelona, 1994.

14 Offe, Claus, Partidos politicos y nuevos movimientos sociales, Sistema, Madrid, 1996. 
Las diversas corrientes del movimiento feminista estuvieron asociadas al pensamiento liberal, al socialista y al denominado radical. Entre las primeras, el referente lo simbolizó Betty Friedan, que en 1966 fundó en los EE. UU. la National Organization for Women (NOW), llegando a ser la organización más importante en aquel país. Friedan define la situación de la mujer como desigual, y no como opresiva o de explotación; por ello propugna medidas reformistas de tipo legal que corrijan esa situación. La NOW estimaba que las leyes debían regular con más atención el asunto de la exclusión de la mujer del mercado de trabajo e incidía en la idea de que las mujeres tenían que ocupar más puestos públicos, porque hasta entonces estaban reservados en la práctica totalidad para los hombres. Este feminismo centró su atención de manera principal en las mujeres de clase media y desatendió el punto de vista de clase social.

Fueron las feministas políticas o «radicales», junto con las socialistas, las que introdujeron la cuestión de clase en el enfoque del feminismo. Ambos grupos, nacidos bajo los ecos de 1968, entendieron que las desigualdades estructurales de la sociedad capitalista hacían que el asunto de la marginación de la mujer transcendiese el mero problema legal. Las feministas que fundan el Movimiento de Liberación de la Mujer reivindican la necesidad de separar su estructura y su trabajo de las organizaciones de clase (partidos y sindicatos) generales, y propugnan formar organizaciones específicas de mujeres. El debate entre estos dos sectores - las socialistas y las radicales - se centró en el hecho de que unas consideraban que la liberación de la mujer tenía que venir de la lucha conjunta con los varones por el cambio del sistema capitalista, mientras que las otras opinaban que la lucha debía ser separada, y que en una sociedad poscapitalista el problema de género seguiría presente a menos que las mujeres mantuviesen su independencia organizativa.

El feminismo armó un bagaje teórico amplio que incorporó el marxismo, el psicoanálisis y el anticolonialismo. De ahí surgen nuevos conceptos para enfocar los estudios, como patriarcado y género. Estas feministas estiman que la dominación de clase y de raza se levanta sobre la dominación patriarcal. Este punto de vista promueve la idea de que son todos los varones, en sus distintas clases o culturas, los que se benefician del patriarcado, por el hecho de ser varones. Las feministas incorporan nuevos puntos de vista, que trascienden los análisis sociológicos hechos hasta la fecha, para abordar la explotación de la mujer en las distintas sociedades contemporáneas ${ }^{15}$.

En este capítulo, un apartado especial merece el movimiento de los afroamericanos en su lucha por los derechos civiles. Este movimiento estuvo influido

${ }^{15}$ De Miguel, Ana, http://www.mujeresenred.net/anademiguel.html (visitado 14/1/2015). Sole Romero, Gloria, Historia del feminismo (siglos XIX y XX), EUNSA, Navarra, 1995 . 
y a la vez influyó al resto de los habidos en la década de los sesenta, aunque su radio de acción estuvo circunscrito a los EE. UU.

El escenario de los negros norteamericanos en el sur del país era de apartheid. Estaban segregados, humillados y explotados. Su situación no se correspondía con la de los habitantes de una nación avanzada y democrática. La estructura del racismo no había sufrido mella en el sur. Es tradicional considerar que la lucha comenzó con el boicot a las guaguas en Montgomery en 1955, en protesta por los asientos preferentes y segregados que usaba la compañía. Otros altercados y resistencias se venían sucediendo. El acto simbólico que da inicio a la protesta fue cuando Rosa Parks, una costurera negra, se negó a levantarse del asiento para dejar que se sentara una persona blanca. Tras ese gesto comenzó la campaña de boicot, que duró más de un año y logró abolir la ley local que respaldaba la medida segregacionista. El éxito estuvo en buena medida orquestado por la participación de Martin Luther King, que, con su gente, recorrió las ciudades del sur enarbolando la bandera de esa causa. A partir de ahí se convirtió en un referente de alcance nacional (y mundial) en la lucha por el reconocimiento de la igualdad. Luther King era un pastor de la Iglesia bautista comprometido en la defensa de los afroamericanos. Aprovechó la existencia de la NAACP (Asociación Nacional para las Personas de Color), que se había creado en 1909, para desde ella impulsar que los negros se inscribiesen en los censos electorales y de esta manera llevar a sus representantes a las instituciones. Esta lucha fue difícil porque en Alabama la violencia policial, y de la sociedad en general contra los negros, imposibilitaba la práctica de tales derechos. Posteriormente, Luther King y otros activistas crearon el Southern Christian Leadership Conference para entrenar, asistir y recolectar fondos en la lucha.

Luego vinieron otras campañas para derribar el muro de la segregación en el ámbito educativo y de los derechos políticos. La filosofía de Luther King consistía en una resistencia no violenta, pero sí persistente en la consecución de las demandas exigidas. Recordaba claramente el activismo de Gandhi en la India en la lucha por la independencia. Las acciones consistían en sentadas, manifestaciones, demandas legales, campañas por todo el país. El movimiento en pro de los derechos civiles de los afroamericanos continuó durante toda la década y en el camino fueron asesinados destacados líderes, entre ellos el propio Luther King (1968) y anteriormente Malcom X (1965), quien abogada por el uso de la violencia para defenderse de la violencia de los racistas blancos. Malcom X fue inspirador de la creación del Partido de los Panteras Negras (1966), aunque no pudo ver su nacimiento ${ }^{16}$.

${ }^{16}$ Abu-Jamal, Mumia, Queremos libertad. Una vida en los Panteras Negras, Virus, Barcelona, 2008. 
El movimiento cobró gran fuerza y extensión por todos los EE. UU. e influyó en los líderes sociales del país. Se retroalimentó del movimiento pacifista y antiguerra de Vietnam, del movimiento hippie y del pensamiento anticolonialista de los países periféricos. Los deportistas y artistas negros, así como los pensadores liberales blancos y las organizaciones de la sociedad civil norteamericana, apoyaron este movimiento. Para la historia del pueblo norteamericano este movimiento tuvo una importancia capital: aunque las prácticas racistas no desapareciesen del todo, ya no iban a estar protegidas por las legislaciones segregacionistas que existían hasta entonces ${ }^{17}$.

17 Cantor, Norman F., La era de la protesta, Alianza, Madrid, 1973. 

5. EL FINAL DEL FASCISMO EN GRECIA, PORTUGAL Y ESPAÑA 

Al finalizar la Segunda Guerra Mundial, quedaron en Europa occidental dos países con regímenes fascistas: Portugal y España. Grecia se incorporó a esta tríada en 1967, merced a un golpe de Estado militar auspiciado por la CIA. Estos tres países con historias divergentes, aunque mucho más similares entre los dos primeros, emprendieron el camino a la democracia de diferentes maneras, pero muy coincidentes en el tiempo. Grecia y Portugal lo hicieron en 1974 y España en 1975 .

Desde el punto de vista económico, los tres países estaban situados en la semiperiferia del capitalismo central, ubicado en los países del norte y Gran Bretaña. Las dictaduras perduraron tan largo tiempo por el escenario de guerra fría que se vivía en Europa y el mundo. Tanto en la península ibérica como en Grecia, la confrontación entre los EE. UU. y la URSS explicó la anomalía de unos regímenes que eran profundamente denostados en las organizaciones internacionales.

\subsection{CRISIS ECONÓMICA Y ENERGÉTICA}

Los años setenta se iniciaron en el plano económico con una crisis que azotó al capitalismo mundial. Las consecuencias de la guerra de Vietnam arrastraron a la economía norteamericana hacia el déficit y la inflación y supusieron el fin del anterior periodo de crecimiento sin sobresaltos que había experimentado el capitalismo en las tres décadas posteriores a la Guerra Mundial.

Hubo dos fuertes terremotos económicos. El primero fue el financiero de 1971 y el segundo, la subida de los precios del petróleo en 1973. Esta segunda crisis tuvo su origen en la guerra del Yom Kipur y en la respuesta árabe: subida de los precios del petróleo por el apoyo euro-norteamericano a Israel, a lo que se sumó el interés propio de las multinacionales del sector. La crisis afectó sobre todo a los países de Europa occidental.

La convertibilidad del dólar en oro se había establecido en los acuerdos de Bretton Woods a 35 dólares la onza de oro, en un momento en que las divisas de oro del Gobierno de los EE. UU. representaban más del $60 \%$ de las reservas mundiales. En las décadas siguientes, este criterio se mantuvo porque las reservas seguían siendo grandes, pero desde 1970 la balanza del comercio exterior 
norteamericano comenzó a ser deficitaria. Esto hizo que cada vez más dólares estuviesen en manos de gobiernos y capitales extranjeros. La convertibilidad del dólar a 35 onzas ya no era posible. El Gobierno suspendió la venta del metal precioso a particulares. Algunos aliados (como Gran Bretaña) pidieron en 1971 recuperar 3.000 millones de dólares en oro depositados en las reservas norteamericanas, lo que ayudó a acelerar la decisión de suspender la convertibilidad ${ }^{1}$. «Con esta medida, que desligaba al dólar del oro, se liquidaba el sistema creado en Bretton Woods para mantener el equilibrio monetario internacional y se entraba en una etapa de regulaciones mucho más complejas y mucho menos eficaces. Liberados de la obligación de mantener un equilibrio entre los dólares emitidos y sus reservas, los gobernantes norteamericanos entraron por el camino que iba a conducir a un enorme endeudamiento y, a la larga, a la grave crisis económica de comienzos del siglo XXI» ${ }^{2}$.

Los franceses también hicieron algo similar y fueron a retirar su oro del depósito norteamericano. El fin de la convertibilidad del dólar dejó a Europa y a Japón en una difícil posición. La devaluación del dólar los obligaría a hacer lo mismo con sus monedas y eso provocaría una subida de los precios de la energía. El desenganche del dólar del oro generó una subida espectacular del valor del metal precioso, que se puso a finales de la década (1979) en los 455 dólares la onza $^{3}$. La temida devaluación de la moneda americana ayudó a sus exportaciones, al verse beneficiadas frente a las alemanas y las japonesas.

Los precios de las materias primas subieron sensiblemente desde 1973, en especial el petróleo, lo cual afectó sobre todo a las economías de Europa occidental y de Japón. EE. UU. no sufrió la subida porque las transacciones se hacían con su moneda nacional; más bien al contrario, esta situación le ayudó a financiar su déficit, porque las grandes compañías que se beneficiaron de las subidas eran norteamericanas y porque además las grandes reservas de divisas de sus socios petroleros fueron a invertirse en las empresas estadounidenses y en Wall Street. Los capitales del mundo fluían hacia EE. UU. Eso explica el hecho de que todos los países aliados de los EE. UU. y productores de crudo subiesen los precios del producto sin encontrar resistencia de parte del Gobierno Nixon y las posteriores administraciones ${ }^{4}$. Desde esta perspectiva, la crisis energética de 1973, más que de carácter global, habría que considerarla como parte del juego de equilibrio entre la potencia central (EE.UU.) y sus aliados competidores

${ }^{1}$ Fontana, Josep, Por el bien del imperio. Una historia del mundo desde 1945, Pasado y Presente, Barcelona, 2011.

${ }^{2}$ Ibíd., p. 457.

${ }^{3}$ Varoufakis, Yanis, El minotauro global. Estados Unidos, Europa y la economía mundial, Capitán Swing, 2013.

${ }^{4}$ Ibíd. 
Europa-Alemania-Japón, sobre los cuales sí hubo un efecto muy importante de la subida de los precios del petróleo, siendo además todos ellos muy deficitarios respecto al oro negro, lo cual no era el caso estadounidense.

\subsection{La ReVOlución de LOS Claveles}

Portugal era una dictadura desde 1926. Y también era un imperio colonial considerable. El Imperio africano de Portugal albergaba las colonias de Angola, Mozambique, Guinea Bisau y Cabo Verde, a las que se sumaba Timor Oriental, en Asia. La dictadura pudo capear la derrota del fascismo gracias al apoyo de los británicos, en cierta forma de manera similar a como había ocurrido en España con la dictadura franquista; aunque Portugal tuvo una cobertura internacional mayor que España gracias a que convirtió las Islas Azores en base de operaciones para los norteamericanos durante la Segunda Guerra Mundial. Aquello le valió ser miembro de la OTAN desde el primer momento (1949) y tener por ello un respaldo mayor en la arena internacional que su vecino ibérico. No obstante, no fue admitida en la ONU hasta 1955, igual que España, y la diplomacia lusa estuvo hostigada y sola en la política internacional, aunque recibió el apoyo incondicional de Franco, igual que este recibía el de la dictadura salazarista ${ }^{5}$.

Portugal fue un miembro activo del colonialismo europeo en África y en menor medida en Asia. Desde 1960, en que se abrió el proceso de las independencias a gran escala en el continente africano (17 países lo lograron ese año), su evolución interna estuvo muy condicionada por la política internacional, y sobre todo por el problema colonial. Portugal entró en un proceso de guerras coloniales en 1961 que terminaron por arruinar al país y al régimen de SalazarCaetano en abril de 1974.

La dictadura había creado una oligarquía muy pequeña que detentaba la riqueza nacional. En 1973 siete grandes monopolios financieros industriales controlaban el grueso de la economía. En el sector agrícola la situación era bastante similar y una pequeña minoría poseía las mejores tierras: el 2,5\% de los propietarios ostentaban el $70 \%$ del área cultivada o de las mejores tierras para producir. En ese contexto de desigualdad, el país mantenía a 120.000 soldados desplazados a las guerras africanas. Para los jóvenes, el servicio militar era muy prolongado (cuatro años) y tuvo consecuencias dramáticas, ya que en la guerra de Angola se contabilizaron 15.000 muertos y más de 30.000 heridos en el bando colonialista.

En el interior, la policía política PIDE (Polícia Internacional e de Defesa do Estado) detenía y torturaba a los opositores en cantidades cada vez mayores

${ }^{5}$ Carcedo, Diego, Fusiles y claveles. La revolución del 25 de abril en Portugal, Temas de Hoy, Madrid, 1999. 
a medida que la situación se fue degenerando. El panorama, además, se agravó por los efectos de la crisis financiera de 1971 y la energética de 1973. La inflación y el empeoramiento de las condiciones de vida animaron un ciclo de huelgas en el sector industrial y de los jornaleros del sur, así como entre la juventud, que se solidarizaba con las luchas de los pueblos colonizados y con los vietnamitas frente a los norteamericanos. El sindicalismo de ascendencia comunista, Confederación General de los Trabajadores Portugueses-Intersindical Nacional (CGTP-IN), ligado al PCP, jugó un papel importante en este tipo de movilizaciones desde 1973 en adelante.

A todo ello se sumó la creación del Movimiento de las Fuerzas Armadas (MFA) en el seno del ejercito portugués. El movimiento nació entre la oficialidad media, y fue posible por la politización y conciencia que adquirieron estos cuadros intermedios en las colonias, en donde comprendieron lo justo de la lucha de los pueblos contra el colonialismo portugués. La toma de conciencia les hizo preparase para afrontar el golpe que derrotaría la dictadura en abril de 1974.

El MFA se creó en 1973 y enarboló un programa democrático de progreso para el país. El activismo de estos suboficiales fue calando en el ánimo de la tropa y produciendo un giro hacia la izquierda del grueso de esta, que acompañó la creciente protesta de la sociedad civil contra la dictadura. El 1 de enero de 1973 un grupo de activistas anticolonialistas, coincidiendo con el Día Mundial de la Paz, se encerraron en la iglesia de Rato, en Lisboa. Entre los encerrados había gente que procedía de diferentes ámbitos ideológicos, algunos cristianos, otros no, y también personas de distinta proyección social: catedráticos, trabajadores, etc. Iniciaron una huelga de hambre, pero al día siguiente la policía entró en la iglesia y detuvo a 70 personas que, sin embargo, serían liberadas con prontitud.

Dos meses después, a comienzos de marzo, miembros de las denominadas Brigadas Revolucionarias (BR) atentan contra una oficina de reclutamiento militar. En los meses siguientes fueron atacadas nuevamente oficinas de organismos oficiales, siendo lo más destacado el ataque con explosivos al Ministerio de Trabajo y el sabotaje al navío de guerra Niassa, que transportaba tropas a Guinea Bissau ${ }^{6}$. El ascenso del enfrentamiento protagonizado por organizaciones revolucionarias fue acompañado en el tiempo con la preparación del golpe militar de los Capitanes de Abril, que acabaron con la dictadura el 25 de abril de 1974.

Una vez derrotada la dictadura, la experiencia revolucionaria permaneció abierta hasta noviembre de 1975. En todo ese tiempo las distintas facciones revolucionarias estuvieron disputándose la hegemonía del proceso con distinta suerte. La injerencia anglo-norteamericana fue constante en el largo año y medio que duró el proceso, y las facciones de la izquierda portuguesa - los sectores

${ }^{6}$ Saraiva de Carvalho, Otelo, Alvorada em abril, Notícias, Lisboa, 1998. 
más revolucionarios del MFA, el PCP y el PSP — muchas veces se encontraron en posiciones enfrentadas.

El proceso revolucionario se vio favorecido por la incorporación de la ciudadanía a la lucha. El 1. ${ }^{\circ}$ de mayo siguiente al día de la revolución, se calculó que más de un millón y medio de personas desfilaron por las calles de Lisboa (Portugal tenía una población de siete millones).

El primer Gobierno tras la caída de la dictadura lo encabezó el general Spínola, apoyado en un primer momento por la izquierda y la derecha. Esta trataría posteriormente de reconstruir su fuerza en torno a la figura del general. Spínola abordó inmediatamente la necesidad de dar solución al problema colonial y finalizar las guerras en África, lo cual ayudó a reforzar su prestigio en el país. El primer Gobierno provisional sumó a la derecha, a comunistas y a socialistas.

No obstante, la derecha y el general Spínola pretendieron copar el poder mediante un golpe orquestado en julio, ante la debilidad política de los partidos de la derecha. El segundo Gobierno provisional estuvo presidido por el coronel Vasco Gonçalves, que era el militar de mayor graduación vinculado con el MFA. Tras la intentona golpista, el MFA creó el Comando Operacional del Continente (COPCON), que estaba bajo la dirección de Otelo Saraiva, un militar del ala izquierdista del MFA. La derecha y Spínola siguieron intentando maniobrar y llevar adelante un golpe que les garantizase el poder de manera incontestable, y efectivamente organizan un nuevo golpe en septiembre de 1974, que será parado por las organizaciones populares cortando las carreteras con barricadas a las masas reaccionarias desplazadas del norte, que harían de cuerpo de choque de los golpistas.

En marzo de 1975, nuevamente Spínola, asesorado por la CIA y en el marco de unas maniobras militares norteamericanas llevadas a cabo en aguas de Portugal, que movilizaron a 10.000 soldados, hizo su último intento golpista. Se planeó que el golpe debería comenzar sitiando el cuartel de Artillería de Lisboa, que era uno de los núcleos centrales del mando del MFA y donde existía un fuerte poder de fuego. Fue sitiado y tiroteado, y se produjo un muerto entre los defensores del cuartel. La operación terminó, sin embargo, con la confraternización de los soldados atacantes y defensores y con la intermediación de los obreros de las fábricas cercanas al cuartel para facilitar el acuerdo. Frustrado el golpe, una enorme manifestación de duelo por el soldado caído recorre Lisboa en una prueba de fuerza antigolpista.

A partir de ese momento el MFA y los militares más reconocidos comienzan a impulsar un proceso hacia el socialismo, llevando adelante una medida clave de institucionalización del movimiento al crear el Consejo Superior de la Revolución y establecer un canal de comunicación permanente entre los partidos de izquierda y el MFA. En este momento, y tras las elecciones constituyentes de abril de 1975, en las que el PSP obtiene el 38\% de los votos y los comunistas el $12 \%$, la estrategia de las potencias occidentales se centró en cooptar al PSP y a su líder, Mario Soares. 
Los intentos consecutivos de la derecha por revertir el proceso portugués por medio del golpe de Estado no habían dado los frutos que EE. UU. y Gran Bretaña esperaban. Cuando estas vías quedaron agotadas y desprestigiadas, «el gobierno de Alemania Occidental ofreció a Kissinger métodos distintos para reintegrar a Portugal en la disciplina de la Coalición, [...] penetrar a través de los políticos cooptados, financiarlos y darles el apoyo político bajo cobertura de organizaciones centradas en la propia RFA — las internacionales Demócrata-Cristiana, Socialdemócrata y Liberal- La operación comenzó con Mario Soares»7.

La Revolución llegaba a su final. En noviembre de 1975, un intento golpista de militares paracaidistas de izquierda es derrotado por falta de apoyo y precipitación. Fue el último acontecimiento que pretendió un cambio de rumbo de la Revolución portuguesa hacia el socialismo. Después de ello, el proceso institucional en línea con los intereses de la OTAN y del Mercado Común Europeo hizo de Portugal un país homologado, desde la periferia, al modelo auspiciado por la alianza occidental (EE.UU.-MCE-OTAN) ${ }^{8}$.

\subsection{LA DEMOCRACIA EN GRECIA}

La experiencia griega iba a estar jalonada por otra serie de factores, distintos a los portugueses. Grecia fue ocupada por los nazis durante la Segunda Guerra Mundial, y al finalizar esta se sumió en una guerra civil que enfrentó a los partisanos (comunistas), que ya habían luchado contra el ejército de Hitler, con la derecha griega, que estaba respaldada por los británicos y los norteamericanos y que había apoyado a los nazis. La guerra civil dura hasta 1949 y a su fin es designado Papagos como primer ministro, con el apoyo anglo-norteamericano. En 1952 Grecia es admitida en la OTAN y accede al poder el dirigente derechista Karamanlis. Este hecho ayudó a exacerbar la tensión con Turquía por la soberanía de la isla de Chipre, que los dos países reclaman para sí. En 1964 subió al trono el monarca Constantino II; paralelamente, Papandreu venció en las elecciones generales de aquel año por mayoría absoluta. Las tensiones sociales se dispararon ese año y el siguiente, y manifestaciones de corte antimonárquico y contra el dominio norteamericano en el país llevan a la dimisión de Papandreu y a la formación, nuevamente, de un Gobierno de derechas. No fue suficiente este nuevo Gobierno para impedir el golpe de Estado de los coroneles en abril de 1967, un mes antes de nuevas elecciones que iban a dar un triunfo a una alianza de centro-izquierda.

${ }^{7}$ GARCÉs, Joan E., Soberanos e intervenidos. Estrategias globales, americanos y españoles, Siglo xxi, Madrid, 1996, p. 167.

${ }^{8}$ Sujánov, Viktor, La revolución de los claveles, Progreso, Moscú, 1981. Maxwell, Kenneth, A construção da democracia em Portugal, Presença, Lisboa, 1999. 
El golpe fue preparado por la CIA y ejecutado por los servicios secretos militares griegos. Esa noche y los días posteriores fueron detenidas más de 10.000 personas, entre las que se encontraba Giorgio Papandreu. La Junta Militar griega desplegó una intensa política de represión, tortura y encarcelamientos sin garantías jurídicas mínimas.

La dictadura en Grecia duró hasta 1974. Con poco apoyo popular, sostenida básicamente sobre la represión y sin consensos interiores, su aventura militar en Chipre acabó por destruir el régimen. Los coroneles griegos financiaron un golpe en Chipre al objeto de sustituir al arzobispo Makario e instalar un Gobierno títere que respondiese a los intereses griegos. El plan no salió como esperaban porque los turcos invadieron la parte norte de la isla. Se desató la guerra, lo que adelantó el fin de la dictadura en Grecia. Caídos los coroneles, se abolió la monarquía, con un $70 \%$ de votos a favor de la república, y se redactó una nueva Constitución.

Los norteamericanos fueron señalados por la población como culpables de la dictadura y de la aventura en Chipre, lo que llevó a que el nuevo ministro, Karamanlis, retirase al país de la estructura militar de la OTAN, tal como había hecho De Gaulle unos años antes con Francia. Las primeras elecciones posdictadura trajeron un Gobierno de centro-derecha capitaneado por Nueva Democracia, el partido de Karamanlis, que obtuvo el $54 \%$ de los sufragios; le siguió la Unión de Centro con el 20\%; el PASOK de Andreas Papandreu con el $13 \%$, y los partidos comunistas, que se presentaron divididos, obtuvieron el $9 \%{ }^{9}$.

La dictadura no había creado unas instituciones propias, sino que se nutrió de las existentes con la monarquía. Como corresponde a la época, todo el periodo de posguerra modificó la estructura social del país, generando procesos migratorios del campo a la ciudad y perfilando un modelo basado en el turismo, las grandes inversiones estatales y un aumento de la producción agrícola. El capital internacional, sobre todo norteamericano y de algunos países europeos, se introdujo de manera masiva, siendo durante la dictadura un $67 \%$ mayor que en épocas anteriores. Este capital se centró en la industria (química, eléctrica, naval). «Grecia había elegido la alternativa de una industrialización marcada por las estructuras de la nueva dependencia y la introducción masiva de capitales extranjeros, antes de la dictadura, proceso que por otro lado se aceleró a partir de 1964 bajo un gobierno no precisamente de derecha, sino de centro (Papandreu padre): la junta no habría hecho más que perseguir el impulso» ${ }^{10}$.

Grecia se convirtió de esta manera en un país intermediario entre el capitalismo de los países centrales y los mercados de los países a los que reex-

${ }^{9}$ Mammarella, Giuseppe, Historia de Europa contemporánea (1945-1990), Ariel, Barcelona, 1990.

${ }^{10}$ Poulantzas, Nicos, La crisis de las dictaduras. Portugal, Grecia, España, Siglo xxi, México, 1976, p. 22. 
portaba, sobre todo los africanos de la ribera mediterránea. Los capitales que se beneficiaron de manera principal de esta relación de dependencia fueron los norteamericanos y franceses. Aunque existía una competencia en términos de países capitalistas, en Grecia y en cualquier lugar, las estrategias de los grandes países son polivalentes y las relaciones con los griegos dependen también de los equilibrios de fuerzas internas en el país. La polivalencia significa que la estrategia imperial estaba dispuesta a adaptarse a las situaciones cambiantes, aunque existían preferencias de elección. Las potencias jugaron con varias cartas a la vez y, en función de cómo fueran desarrollándose los acontecimientos, priorizaron unas u otras. El escenario fue el siguiente:

1. Apoyo a la dictadura hasta casi su final.

2. En su defecto, evolución de la dictadura hacia un sistema legal de parlamentarismo restringido.

3. Apertura de mayor alcance pero bajo control militar.

4. Inicio de un proceso de transición con gobierno centrista y apertura de un espacio para la socialdemocracia, al objeto de canalizar el creciente radicalismo de los trabajadores y de la ciudadanía en su conjunto. Este último fue el camino desarrollado al final ${ }^{11}$.

La estructura política que se generó con la vuelta al sistema parlamentario tendió hacia el modelo de un bipartidismo imperfecto, en el que predominaba en el centro-derecha Nueva Democracia y en el centro-izquierda el Partido Socialista (PASOK). Esa estructura permaneció inmutable hasta la crisis financiera de 2008, la cual ha modificado el mapa político del país.

La tradición de las izquierdas en Grecia se vio influenciada por las protestas europeas de 1968, y por ello incorporó muchas de las críticas y prácticas que la nueva izquierda había difundido, tales como tendencias libertarias y comportamientos antijerárquicos y antiautoritarios. Se afianzaron así el movimiento feminista, los movimientos de ocupación y las prácticas contraculturales ${ }^{12}$.

11 Ibíd.

${ }^{12}$ Kornetis, Kostis, «Las transiciones democráticas Griega y Española en retrospectiva», en http://ifc.dpz.es/recursos/publicaciones/30/99/11kornetis.pdf (visitado 17/1/2016). Gómez Fernández, Ana Belén, «La llegada de la democracia al Mediterráneo: Las transiciones de Portugal, Grecia y España», en HOAL, n. 25 (primavera de 2011), pp. 7-18. 


\subsection{LA TRANSICIÓN EN ESPAÑA}

España, junto con Portugal, era la dictadura fascista más antigua de Europa occidental. Una guerra civil de tres años destruyó la débil democracia inaugurada con la República en 1931. El país se vio sumido en el atraso económico, social y político. Cuando acabó la Segunda Guerra Mundial los países europeos comenzaron a recuperarse de la tragedia de la guerra y a avanzar en sus modelos de democracia social, pero España siguió atrapada en la pesadilla de la dictadura y sus consecuencias de subdesarrollo.

El régimen franquista impulsó una institucionalización construida por las sucesivas leyes emitidas por la jefatura del Estado. Las Leyes Fundamentales del Movimiento fueron las siguientes:

1. Fuero del trabajo, aprobada en 1938, prohibió la existencia de los sindicatos obreros y creó el sindicato único, llamado Organización Sindical Española. Es el sindicato vertical, por su estructura y su manera de funcionamiento.

2. Ley Constitutiva de las Cortes (1942), articuló la forma participativa por medio de sufragios indirectos, en los que se elegían representantes de la familia, el sindicato y el municipio. A esto se le denominó la democracia orgánica.

3. Fuero de los españoles (1945), era la parte de derechos y deberes inspirada en los principios del nacionalcatolicismo.

4. Ley de Referéndum (1945), da potestad al jefe del Estado para convocar plebiscitos al objeto de refrendar leyes.

5. Ley de Sucesión de la Jefatura del Estado (1946), por medio de la cual Franco se arrogaba la potestad de nombrar a su sustituto.

España fue declarada reino, pero no se nombró sucesor de manera formal hasta julio de 1969, en que el dictador designó heredero a Juan Carlos de Borbón. En años posteriores fueron aprobadas la Ley de los Principios del Movimiento Nacional (1958), que perfila el marco jurídico del franquismo; la Ley Orgánica del Estado (1967), en la que se fijan los poderes del jefe del Estado; y en 1976, con el dictador ya desaparecido, se aprueba la Ley para la Reforma Política, que faculta el inicio de las reformas del aparato franquista. Esas fueron las ocho leyes fundamentales. El armazón jurídico de la dictadura.

El régimen franquista se dotó además de duras leyes represivas, que se fueron redefiniendo a lo largo de la dictadura. La primera fue la Ley de Responsabilidades Políticas, aprobada en 1939 y que tuvo como fin aplicar una represión implacable contra los perdedores de la guerra. Centenares de miles de personas fueron encarceladas, muchas de ellas en campos de concentración preparados a tal fin. Ejecutaron a decenas de miles. La represión creó un clima de terror generalizado en la población, que se prolongó durante los largos años de dictadura, aunque los más terribles fueron los diez primeros. La represión paralizó 
cualquier intento de organización opositora, más allá de la acción de grupos de vanguardia (Maquis ${ }^{13}$ ), que no tenían red social de apoyo ${ }^{14}$.

La situación económica era desastrosa. Los primeros quince años son de racionamiento y hambre, mercado negro, corrupción generalizada y sobreexplotación de la mano de obra. El panorama no comenzó a mejorar tímidamente hasta que se firmaron los acuerdos económicos con los norteamericanos en 1953, a cambio de la instalación de las bases militares en suelo español. Luego, con el plan de estabilización de 1959, el impulso de la economía turística, las remesas de divisas enviadas por los dos millones de emigrados y el desarrollo de los polos industriales del norte y el este, el país, tras más de 25 años de dictadura militar, experimentó un crecimiento económico notable, hasta principios de los setenta, en que la crisis mundial tuvo gran impacto negativo en su economía.

España no fue admitida en la ONU hasta 1955, conjuntamente con Portugal y tras los acuerdos con los EE. UU. A la vez que en la ONU, entró en la Organización Internacional del Trabajo (OIT) en 1955, en el Fondo Monetario Internacional y el Banco Internacional de Reconstrucción y Fomento en 1958, en la OECE (Organización Europea para la Cooperación Económica) en 1959 y en el GATT en 1960. De esta manera, los norteamericanos incorporaban a España al bando occidental de la guerra fría y lograban un territorio para su logística y despliegue de inteligencia militar en la retaguardia europea.

En esas circunstancias, el régimen franquista logró su estabilización. La esperanza de los republicanos exiliados de que los aliados, y los norteamericanos en concreto, exigiesen al general Franco una apertura del régimen, elecciones libres y homologación del sistema quedaron defraudadas.

Desaparecida la resistencia armada del Maquis en los cincuenta, y una vez que los republicanos pierden la esperanza de la reinstalación del régimen democrático, una nueva oposición al franquismo comienza a fraguarse en las universidades y en algunos sectores del movimiento obrero. Unas pocas huelgas habían tenido lugar en Vizcaya a finales de los cuarenta, también protestas sociales en Barcelona a comienzos de los cincuenta (boicot a los tranvías en 1951), antes de que en la universidad (Madrid, 1956) se produjesen importantes altercados de los estudiantes demócratas con el fascista Sindicato Español Universitario (SEU). El sindicalismo fascista se vio sometido a una prueba de fuerza en la universidad, en la minería y en las fábricas con el nacimiento, a comienzos de los sesenta, de las Comisiones Obreras. Surgieron como organización espontánea para combatir

13 Serrano, Secundino, Maquis, historia de la guerrilla antifranquista, Temas de Hoy, Madrid, 2002.

${ }^{14}$ Aróstegui, Julio y GÁlvez, Sergio (eds.), Generaciones y memoria de la represión, Universidat de Valencia, 2010. Villarroya Font, Joan y Solé Sabaté, Josep Maria, Cronologia de la repressió de la llengua i la cultura catalanes: 1936-1975, Barcelona, Curial, 1993. 
en el interior de la OSE, y a la postre terminaron siendo el sindicato CC. OO. una vez que la transición comenzó a vislumbrarse.

La relación de esta organización obrera clandestina con el PCE (Partido Comunista de España) y con algunos sectores del cristianismo de base fue consolidando, en el marco de las reivindicaciones laborales, una oposición al franquismo de distinta fuerza y profundidad en los diversos territorios del Estado. En sus primeros diez años la nueva oposición contra la dictadura tuvo un marcado carácter de lucha por la mejora de las condiciones laborales y salariales. El papel de los despachos de abogados laboralistas vinculados a esto fue una característica del proceso español.

El papel central del PCE continuó durante todo el periodo, pero tras 1973 encontró oposición en los sectores más radicalizados del mundo estudiantil y de algunos sectores obreros, dándose de este modo procesos de escisiones diversas del partido. Así nacieron las organizaciones comunistas de la extrema izquierda, nuevos partidos comunistas tales como el Movimiento Comunista, la Liga Comunista Revolucionaria, la Organización Revolucionaria de los Trabajadores, el Partido de los Trabajadores y algunos otros en las distintas nacionalidades. En el caso vasco, es determinante el nacimiento y desarrollo de ETA, que centralizó la oposición en aquel territorio, mientras que en Cataluña fue el PSUC (Partido Socialista Unificado de Cataluña), que era un partido comunista independiente del PCE pero federado a este ${ }^{15}$. Por su parte, el PSOE había sido hasta entonces un partido muy testimonial, prácticamente inexistente durante los largos años de lucha clandestina bajo la dictadura. Entre las organizaciones armadas habría que citar a la mencionada ETA, que comienza sus acciones violentas en 1968, el FRAP (Frente Revolucionario Antifascista y Patriota), que se funda en 1973, dos años antes que el GRAPO (Grupos de Resistencia Antifascista Primero de Octubre), organización armada del PCE (r) (Partido Comunista de España (reconstituido)). En Canarias, las organizaciones opositoras más destacadas y similares a las del resto del Estado fueron también producto de la escisión en el PCE, dando lugar a la OPI (Oposición de Izquierda), el PUCG (Partido de Unificación Comunista en Canarias), PCC (p) (Partido Comunista Canario (provisional)) y, en el terreno de las organizaciones armadas, el MPAIAC (Movimiento para la Autodeterminación e Independencia del Archipiélago Canario), fundado en Argel en 1964, pero entrando a operar en Canarias en 1975.

En general, las grandes líneas programáticas de la oposición fueron dos. Una que abarcaba a los que pretendían una ruptura total con el régimen franquista y otra que pretendía una reforma de este. Estas dos líneas de actuación estuvieron a partir de 1973, enmarcadas en dos bloques a cuya cabeza podríamos

15 Aracil, Rafael, Segura, Antoni y Mayayo i Artal, Andreu, Memòria de la transició a Espanya i a Catalunya Iv: els joves de la transició, Universidad de Barcelona, 2003. 
situar al PSOE y al PCE, aunque estos terminaron convergiendo en 1976. Pero en un principio el bloque reformador estaba compuesto por el PSOE y elementos de tradición demócrata cristiana. El bloque rupturista estaba compuesto por el PCE, los otros partidos comunistas y los nacionalismos de izquierda en las distintas nacionalidades.

Tras el asesinato del presidente Carrero Blanco en 1973, el régimen se quedaba sin un liderazgo sólido e integrador para el posfranquismo. Es decir, se le ponía cuesta arriba mantener el franquismo sin Franco, que es lo que se pretendía hacer desde dentro del aparato de Estado. La elección de Arias Navarro como sucesor de Carrero no aunaba el consenso del aparato, de tal modo que dentro del propio franquismo las distintas familias (militares, movimiento nacional, falangistas, Opus Dei), aunque aparecían como un bloque de cara al exterior, no lo eran internamente. Cuando Franco muere, en noviembre de 1975, el proceso entraba en tiempos de incertidumbre. El régimen estaba débil, pero la oposición también. Una amplísima mayoría de ciudadanos estaba despolitizada, tenía miedo y carecía de orientación política. Exceptuando Euskadi y Cataluña, donde la oposición era mayoritaria política y socialmente, en el resto del país el aparato de Estado y sus derivaciones políticas dominaban la situación.

Hay un primer intento continuista encabezado por el Gobierno Arias-Fraga, que se salda con un fracaso y uso intensivo de la represión. Paralelamente, la oposición PCE-PSOE va encontrando vías de acuerdo para terminar fraguando la Coordinadora Democrática, o "platajunta», organismo que aunaba al grueso de la oposición política. Tras la destitución de Arias y el nombramiento de Suárez se entra en un nuevo proceso en el que la presidencia del Gobierno tratará de llevar la dirección. Se convoca el referéndum para la reforma política, que es la primera iniciativa de envergadura de Suárez. Recibe el apoyo mayoritario para emprender su plan. El referéndum trató de ser contestado con una huelga general convocada por el PCE, pero no tuvo el eco esperado. La oposición pasó a estar a la defensiva y a asumir la necesidad de negociar el proceso con el Gobierno Suárez. Con la legalización del PCE-PSUC en abril de 1977 se entra de lleno en el plan del Gobierno.

En octubre de 1977 se acuerda un plan anticrisis económica y político que se denominó los Pactos de la Moncloa. Estos marcaron el itinerario para el año siguiente hasta la aprobación de la Constitución en diciembre de 1978. Los pactos fueron firmados por el PSOE, el PCE y los nacionalismos de centro-derecha. Alianza Popular suscribió el acuerdo económico, pero no el político. Firmó también CC. OO., sindicato de obediencia al PCE; la UGT, de obediencia al PSOE, se opuso primero, pero terminó firmando posteriormente.

Desde la llegada de Suárez al poder la oposición mayoritaria reordenó sus prioridades. Si originariamente los opositores se dividían entre rupturistas y pactistas, ahora estos habían llevado a la mayoría a su posición. Los elementos diferenciados de los dos modelos estribaban en los siguientes puntos. La ruptura implicaba la apertura de un proceso constituyente que conllevaba referéndum 
para elegir la forma de Estado (monarquía o república). Depuración de los cuerpos represivos y de otras instancias asociadas al mantenimiento de la dictadura. Creación de un Gobierno provisional compuesto por los protagonistas de la oposición. Amnistía inmediata para todos los presos políticos y sociales. Reconocimiento de las nacionalidades y de su derecho de autodeterminación. Los reformistas promovían, por su lado, una paulatina apertura y negociación entre el Gobierno tardofranquista y los elementos moderados de la oposición. Mantenimiento de la monarquía y elaboración de una Constitución que legalizaría lo que iba a perdurar del franquismo (continuismo de los cuerpos represivos y de las otras instancias del franquismo). Exclusión de la izquierda radical, en un principio incluido el PCE. Amnistía limitada y paulatina. Unidad de España y descentralización administrativa de las «regiones».

Finalmente, el modelo resultante fue una mezcla de ambos postulados, pero con muchos más ingredientes del modelo pactista que del rupturista. La Constitución fue elaborada por el grupo de políticos adscritos a las principales fuerzas parlamentarias, resultantes de las elecciones generales de 1977. Con la aprobación de la Carta Magna se comenzó a fraguar una nueva elite política procedente de los partidos opositores, que, junto con los franquistas reformistas, representaron nuevo personal político en la España democrática.

Sin embargo, las tensiones generadas por el terrorismo, sobre todo de ETA, y la amenaza golpista mantuvieron al país en situación de estabilidad precaria, que se rompió finalmente con la intentona golpista de febrero de 1981. El fracaso del golpe agotó y terminó de desprestigiar a las fuerzas más reaccionarias del país. El triunfo del PSOE en octubre de 1982 por amplia mayoría absoluta daba un impulso definitivo a la estabilización de la monarquía parlamentaria. Con la entrada en el Mercado Común Europeo en 1986, y con la ratificación de la entrada en la OTAN también ese año, España quedaba finalmente insertada y estable en el bloque de los países eurooccidentales. Se cerraba así definitivamente el ciclo de la transición abierto formalmente con la llegada de Suárez al poder en junio de $1976^{16}$.

${ }^{16}$ Gallego, Ferran, El mito de la transición: la crisis del franquismo y los orígenes de la democracia (1973-1977), Crítica, Barcelona, 2008. Míguez GonzÁlez, Santiago, La preparación de la transición a la democracia en España, Universidad de Zaragoza, 1990. 

6. LAS DICTADURAS EN EL CONO SUR AMERICANO 



\subsection{La Operación Cóndor}

La Operación Cóndor es el nombre dado a un plan de contrainsurgencia desarrollado en los países del Cono Sur americano. Las distintas dictaduras militares pusieron en coordinación a la inteligencia militar de cada uno de los países para secuestrar, torturar y asesinar a la disidencia política. Las naciones implicadas fueron Argentina, Chile, Brasil, Paraguay y Bolivia, más adelante se sumaron Perú y Ecuador.

Las revelaciones sobre este plan saltaron a la luz en 1992, cuando se descubrió el llamado «archivo del terror», que estaba ubicado en la capital de Paraguay, Asunción. Ahí se encontró la documentación que probaba la existencia de esta gran operación de contrainsurgencia, que había estado avalada y asesorada por la CIA y que causó la muerte de 50.000 personas, 30.000 desapariciones forzadas y el encarcelamiento de 400.000 latinoamericanos.

Las dictaduras en el Cono Sur fueron arropadas por los distintos gobiernos de los EE.UU., cuando no promovidas e instauradas por ellos mismos. La más antigua de las dictaduras era la que existía en Paraguay, cuyo hombre fuerte se llamaba Alfredo Stroessner y que había sido instaurada en 1954. Luego vino la de Brasil en 1964, cuando merced a un golpe militar se apartó del poder al nacionalista de izquierda Joao Goulart. En Bolivia accedió al poder el militar Hugo Bánzer en 1971; Augusto Pinochet en Chile en 1973, derrocando al Gobierno del socialista Salvador Allende, quien ostentaba el cargo de presidente de la República desde 1970. En Argentina, la Junta Militar se hizo con el poder después de una cruenta represión en 1976. Antes había sucedido lo mismo en Uruguay, con el golpe cívico-militar de 1973. Con anterioridad en muchos de estos países se habían producido golpes de Estado y posteriores retornos a sistemas liberales, pero siempre en condiciones de mucha debilidad institucional, vigilados o amenazados por el poder militar y por la injerencia norteamericana.

Formalmente la operación arrancó con una primera reunión de «trabajo» que tuvo lugar en Santiago de Chile en noviembre de 1975. Chile y Argentina fueron el centro y motor del plan. Las policías políticas de ambas dictaduras, DINA (Dirección de Inteligencia Nacional) en el caso chileno y SIDE (Secretaría de Inteligencia de Estado) en el argentino, estuvieron a la vanguardia del 
proceso. Además de la consabida participación de la CIA, los servicios secretos franceses también jugaron un destacado papel en el asesoramiento y entrenamiento de sus homólogos latinoamericanos, adiestrándolos en las operaciones de contrainsurgencia que los franceses habían puesto en práctica en la guerra de independencia de Argelia entre 1954 y $1962^{1}$.

En los tres epígrafes siguientes veremos el desarrollo de los procesos en Argentina, Brasil y Chile.

\subsection{Argentina: del Peronismo a la Junta Militar}

La historia de Argentina en la segunda mitad del siglo xx está jalonada de procesos de gran intensidad. Con Perón, el país inicia el camino de la modernización capitalista. Juan Domingo Perón había llegado al Ministerio de Trabajo con el golpe militar de Pedro Pablo Ramírez y con el apoyo de Edelmiro Farrel, entonces ministro de la Guerra. Este ministerio tenía bajo su responsabilidad el Departamento Nacional de Trabajo, a cuya cabeza situó a Perón. Desde ahí impulsó en 1944 el Estatuto del Peón, un documento que trataba de proteger a los campesinos y trabajadores rurales.

En 1946 se presentó a la presidencia de la República con el Partido Laborista y la Unión Cívica Radical-Junta Renovadora, alcanzando un $56 \%$ de los votos. Su primer periodo al frente de la República fue el mandato 1946-1951, durante el cual se dibujaron las líneas de actuación política del peronismo. Sus características básicas, que luego serán patrimonio del legado justicialista, las conforman un impulso fuerte al desarrollo industrial y la nacionalización de los ferrocarriles y de la telefónica, todo ello adornado con un radical discurso izquierdista, pero que, sin embargo, no tocó los intereses de los grandes propietarios de tierras y de ganado, donde se concentraba la oligarquía argentina verdaderamente poderosa, lo cual fue interpretado como un guiño hacia esos sectores. También arbitró medidas de censura de prensa y de inflación de los precios.

La política social de este periodo es la que tuvo a la postre un mayor reconocimiento por parte de los argentinos. Estuvo dirigida por Eva Perón e hizo posible el realce y adoración de su figura en el país hasta la actualidad. Eva impulsó la creación de escuelas públicas, hospitales, residencias para ancianos y estudiantiles para las clases pobres del país. Mejoró los salarios para los trabajadores y promulgó el reconocimiento de sus derechos. Alentó políticas hacia la

1 Paredes, Alejandro, «La Operación Cóndor y la guerra fría», Revista Universum n. ${ }^{\circ}$ 19, vol. 1: 122-137, Talca, 2004. Https://www.youtube.com/watch?v=6-Sz1A2_80A (visitado 20/1/2016). Calloni, Stella, Los años del lobo. Operación Cóndor, Continente, Buenos Aires, 1999. 
consecución del pleno empleo por medio de grandes obras públicas. En cierta forma fue el desarrollo de un modelo parecido al New Deal de Roosevelt en el caso norteamericano, pero en condiciones distintas.

Esta primera presidencia de Perón dio nacimiento a lo que se ha denominado el populismo. Esta forma de operar políticamente se caracteriza por el uso del radicalismo verbal, el llamamiento a la movilización de las masas, pero paralelamente haciendo guiños a los sectores oligárquicos. En la política económica es una combinación de autoritarismo y paternalismo magnánimo, usando un discurso nacionalista y antiimperialista. Está dirigido a una masa interclasista y se sostiene sobre un liderazgo caudillista y la defensa de los intereses corporativos.

El segundo Gobierno de Perón bajó la intensidad de su populismo, promoviendo de manera más positiva las relaciones con los EE. UU. y dejando de lado los discursos antiimperialistas. Ello estaba en la antesala de importantes tratados comerciales con algunas multinacionales norteamericanas, en especial con la Standard Oil. Además, en este segundo Gobierno se congelaron los salarios de los trabajadores para tratar de contener la inflación y los problemas de solvencia económica. El segundo mandato se vio truncado de forma abrupta por el golpe militar de 1955, que desalojó a Perón de la Casa Rosada. El golpe fue promovido por la oligarquía, parte del ejército y la Iglesia.

El Gobierno militar, que se extendió entre 1955 y 1958, acometió enseguida la desnacionalización de los sectores económicos que Perón había nacionalizado e inició una apertura total a la introducción del capital norteamericano. Esta experiencia fue seguida de un Gobierno cívico-militar entre 1958 y 1962. Esta nueva Administración, dirigida por Frondizzi, trató de ser de unidad nacional y por ello les dio entrada a miembros del peronismo. Esta apertura no gustó en ciertos sectores militares, que dan un nuevo golpe de Estado en 1962, y tras promover unas elecciones fraudulentas colocan en la presidencia al candidato militar Illía. La dictadura se prolongó de manera ininterrumpida hasta 1973, con tres militares en la presidencia de manera consecutiva (Onganía, Levingston y Lanusse).

Durante estos gobiernos se produjeron importantes movimientos de masas obreras y estudiantiles, y revueltas de mucha consideración en Buenos Aires, Córdoba, Santa Fe y Tucumán. Asimismo, se organizaron los movimientos guerrilleros de los Montoneros y del Ejército Revolucionario del Pueblo. La lucha armada de base urbana se extendió por las grandes ciudades argentinas, en especial por Buenos Aires.

El capital multinacional, que había tenido las puertas abiertas durante la permanencia de todos estos gobiernos militares, se introdujo de manera masiva en el país y controló la petroquímica, automóviles, tabacos, neumáticos y tractores. Este capital norteamericano estaba a su vez controlado por la banca JP Morgan y Rockefeller.

Durante el periodo anterior al golpe de la Junta Militar hubo un último Gobierno peronista, pero esta vez claramente de derechas (1973-1976). En este periodo estuvieron al frente Campora (1973-1974) y María Estela Martínez de 
Perón, la segunda mujer de Perón, que gobernó en combinación con el extremista de derechas López Rega (1974-1976). Este Gobierno era muy represivo y conllevó un aumento de las acciones insurreccionales por parte de las guerrillas.

En 1976 se produce un golpe de Estado encabezado por una Junta Militar, sin duda el más sanguinario de los habidos en la historia del país, instaurándose una dictadura hasta 1983. La Junta estaba encabezada por el triunvirato compuesto por Massera-Videla-Agosti. Se puso en práctica una actividad terrorista de Estado de gran amplitud, en el marco de la Operación Cóndor antes mencionada. La Junta Militar suspendió toda actividad política e ilegalizó los partidos y los sindicatos. Prohibió las huelgas, disolvió el Congreso y destituyó a la Corte Suprema de Justicia. Clausuró los locales de actividad nocturna (bares, etc.) y ordenó el corte de pelo a los hombres. Se censuraron libros y revistas. También quedó suspendido el Estatuto del Docente, para así tener manos libres en la represión llevada a cabo en las universidades, que, junto con las fábricas, fueron los lugares más golpeados por la represión.

La puesta en práctica de las detenciones ilegales, torturas y desapariciones de los detenidos se convirtió en moneda común y diaria. La represión la llevaron a cabo militares camuflados de civiles, todo orquestado y dirigido desde la cúpula del Estado. Las estimaciones de los organismos de derechos humanos cifran en 30.000 el número de desaparecidos, y los sectores sociales golpeados fueron prácticamente todos, aunque la mayoría eran miembros de la clase obrera industrial y estudiantes de las universidades ${ }^{2}$.

En el plano de la economía, la Junta impulsó un liberalismo extremo apoyado por el FMI-BM, los bancos extranjeros y los organismos internacionales. Terminó con el intervencionismo de Estado en la economía. Congeló los sueldos nuevamente y Argentina entró en un proceso crítico de endeudamiento exterior, que los gobiernos posteriores, tras el retorno de la democracia, no hicieron sino aumentar. La crisis de 2001 y la bancarrota del país tuvieron sus orígenes en los planes económicos de la dictadura.

La Junta finalmente cayó, atosigada por los problemas económicos, la crisis política y la guerra de las Malvinas contra Gran Bretaña. La derrota ante las fuerzas de Su Majestad hundió al régimen y su poca credibilidad interna. Los militares argentinos mandaron a luchar a jóvenes mal equipados contra uno de los ejércitos modernos más poderosos del planeta. En menos de dos meses tuvieron que rendirse y con ello cayó la propia dictadura.

2 Caparrós, Martín y Anguita, Eduardo, La Voluntad. Una historia de la militancia revolucionaria en la Argentina, Booket, Buenos Aires, 2006. Mattini, Luis, Los perros, Continente-Pax, Buenos Aires, 2006. 


\subsection{Brasil: del Estado Novo a la democracia}

Brasil es el mayor país de América del Sur por extensión geográfica y población. Es la gran potencia del sur, pero con los enormes problemas típicos de las sociedades dependientes. La República brasileña quiso reinventarse durante el periodo conocido como la República Nova, que se prolongó desde 1945 hasta 1964. Esta República vino a sustituir al Estado Novo de Getulio Vargas, quien había sido un émulo del salazarismo portugués. Vargas accedió al poder en 1937 tras una guerra civil de la que salió victorioso. Disuelve el Congreso Nacional, elabora una nueva Constitución y convoca elecciones. En 1946, con la Carta Magna aprobada, se restauran los derechos individuales y se instaura un régimen democrático durante el cual se traslada la capital desde Río de Janeiro hacia Brasilia, ciudad futurista diseñada por el arquitecto Niemeyer. En este periodo se considera que cristaliza el populismo en Brasil, que se retroalimenta con el nacionalismo y el desarrollismo.

Vargas mantiene la presidencia entre 1950 y 1954. Le sustituye Kubitschek, que la ostenta entre 1956 y 1961. Tras él asumió el poder Quadros, que, sin embargo, delegó en su vicepresidente, Joao Goulart, en el mismo año de su toma de posesión. Goulart es considerado el presidente populista por excelencia. Durante su mandato se impulsó la reforma agraria para dar respuesta al que era entonces el principal problema social del país, la concentración de tierras y la existencia de millones de campesinos sin campos que trabajar. Este atrevimiento, al tocar los intereses de los grandes propietarios latifundistas, fue probablemente una de las principales causas que motivaron el golpe de Estado para sacarlo del poder. Junto con la reforma agraria, puso en marcha medidas de reforma social en beneficio de millones de pobres.

Las oligarquías tradicionales no estaban interesadas en ese tipo de problemas y, junto con la CIA, provocaron un golpe de Estado en 1964 e instauraron una dictadura militar que se prolongó durante veinte años, aunque con una evolución interna remarcable. El golpe elevó al poder a Castelo Branco. La dictadura se encontró con organizaciones de izquierda que se armaron e hicieron oposición también desde el uso de la violencia política. La oposición estaba conformada por una alianza entre los trabajadores, los estudiantes y la Iglesia de los pobres, la cual venía buscando redefinirse después de la celebración del Concilio Vaticano II. Lo hizo elaborando una doctrina social que se denominó la Teología de la Liberación ${ }^{3}$, que tuvo desde el principio y hasta la actualidad un fuerte compromiso social en defensa de los sectores pobres de ese inmenso país.

La oposición a la dictadura sufrió escisiones y mantuvo estrategias enfrentadas, hasta el punto de que en 1967 el Partido Comunista de Brasil se divide, porque hay sectores que no comparten el uso de la lucha armada. En 1974, la dictadura

${ }^{3}$ Berryman, Phillip, Teología de la liberación, Siglo xxi, México, 1989. 
promueve una tímida reforma convocando elecciones que gana el oficialismo, pero en las que la oposición, agrupada en el MDB (Movimiento Democrático de Brasil), logra unos buenos resultados. En 1978 el MDB gana las elecciones al Senado, aunque lo importante fue su triunfo en las principales ciudades del sur: Río de Janeiro, Sao Paulo y Porto Alegre.

En 1979 la oposición del MDB se escinde en varios grupos y de ahí nacen el PT (Partido de los Trabajadores) y el PMDB (Partido del Movimiento Democrático Brasileño). El PT fue un partido representativo de los obreros y asalariados y planeaba entre sus objetivos una reforma hacia el socialismo. Es crítico, sin embargo, con la URSS, lo cual lo aleja de alianzas con el PCdoB (Partido Comunista del Brasil), que era comunista clásico y prosoviético, y el PCB. El PT tenía muchas características de un frente político en el que estaban presentes las corrientes socialdemócratas, los leninistas, los trotskistas y las corrientes del cristianismo de la Teología de la Liberación.

Paralelamente al ascenso de la oposición política, también se produjo un aumento en la intensidad de la protesta social, con el inicio de las tomas de tierras por parte de los campesinos. Este hecho se enmarcó y contextualizó en la lucha por la democracia, dado que el problema campesino afectaba a millones de brasileños. En 1983 se creó la Central Única de Trabajadores (CUT), un sindicato de base proletaria industrial que estuvo asociado al PT desde sus orígenes. Y en 1984 se organizó el primer encuentro del Movimiento de los Trabajadores Rurales sin Tierra (MST), que a la postre sería el movimiento social y campesino más grande del mundo.

A pesar del ascenso de las organizaciones de las izquierdas, el ciclo correspondía aún a las derechas. El mundo estrenaba por entonces la hegemonía neoconservadora en los EE. UU. y Gran Bretaña. En las elecciones generales de 1984, los liberales de Sarney se hacen con el poder bajo las siglas del Partido Frente Liberal (PFL/PMDB). En las nuevas elecciones de 1986, esta vez legislativas y a gobernadores, el PMDB gana nuevamente y lleva el camino de convertirse en un partido-Estado, mezclando los intereses de la organización con los de las estructuras estatales y haciendo de ello un sistema clientelar y corrupto muy introducido en la realidad social del país. La presencia de los movimientos sociales y los sindicatos, así como de los partidos de la izquierda en las instituciones, logró que se elaborara una nueva Constitución en 1988.

$\mathrm{Al}$ año siguiente, en nuevas elecciones presidenciales, accede a la presidencia Collor de Melo. Su periodo fue conocido como la presidencia de la corrupción política, el tráfico de influencias y la defensa de los intereses de las grandes corporaciones. En esas elecciones la socialdemocracia se había escindido del PMDB y había quedado en tercer lugar. El segundo lo ocupó el PT. Las siguientes presidenciales auparon al socialdemócrata Cardoso, quien durante dos legislaturas estuvo al frente de la República (1994-2002). Finalmente, el PT llegaría al poder en 2002, permaneciendo hasta la actualidad bajo las presidencias de Lula y Dilma Rousseff. 
La democracia brasileña incorporó elementos novedosos en la gestión de los asuntos públicos, de manera particular la implementación de los presupuestos participativos, que fue una forma de gestión democrática y directa, por parte de la ciudadanía, de los recursos financieros de las corporaciones locales. La primera experiencia a este respecto la promovió el PT desde que gobernó el Ayuntamiento de la ciudad de Porto Alegre, capital del estado federal de Río Grande del Sur. Luego fue exportada a otras ciudades brasileñas y finalmente mundiales. El programa Hábitat de la ONU la eligió como una forma idónea y democrática de administrar los recursos públicos. Esa gestión avanzaba en democracia participativa y redistribución de la riqueza pública, priorizando las inversiones en los barrios con más carencias. Además, generó medios de comunicación locales, como la televisión, que hicieron posible una comunicación democrática en las ciudades en las que se puso en práctica ${ }^{4}$.

\subsection{Chile: del gobierno de la Unidad Popular al golpe de Pinochet}

La experiencia chilena tuvo un influjo muy fuerte en algunos países europeos, de manera particular en Italia, España y Francia. Los partidos comunistas de estos tres países, sobre todo el italiano, que era con mucho el más importante de Occidente — seguido del francés, más dogmático, y, por último, el español, cuyo enorme crecimiento se presuponía una vez que terminase la dictadura en España-, promovieron a principios de los años setenta el eurocomunismo. En resumen, dejaban de lado el leninismo y la teoría insurreccional para tomar el poder y apostaban por la lucha parlamentaria como única vía al socialismo. El eurocomunismo abandonaba parte de la herencia soviética y pretendía redefinir su papel en el mundo fordista.

Durante esa revisión en profundidad sobre las bases mismas del comunismo y su estrategia, vino a darse en Chile la posibilidad de ver los límites de la teoría. Aunque Chile era un país latinoamericano, no era una república subdesarrollada al uso, con escasa clase obrera industrial y amplio campesinado. Era un país muy urbano con amplio bagaje parlamentario y numerosos sectores proletarios en las ciudades. De modo que el «laboratorio» despertaba un evidente interés entre los eurocomunistas, y en especial entre los italianos, que estaban tratando de llevar a cabo junto con los sectores avanzados de la democracia cristiana un Gobierno denominado de «compromiso histórico», para avanzar en el desarrollo político, social y económico en Italia.

4 Guilherme Mota, Carlos y López, Adriana, Historia de Brasil: una interpretación, Universidad de Salamanca, 2009. SABEr, Emir y García, Marco Aurelio, Brasil 2011-2014: dos proyectos en conflicto, La Habana, 2011. 
Cierto es también que el factor norteamericano era determinante en toda América Latina, incluido Chile, y que tras la Revolución cubana, las administraciones estadounidenses miraban con atención qué tipo de relaciones establecían los gobiernos del sur con la isla caribeña. En cualquier caso, EE. UU. estaba dispuesto a intervenir para mantener a sus aliados controlados tanto en este continente como en Europa, como se vio en Grecia en 1967 o como hubiese hecho en Italia de haber salido adelante el «compromiso histórico».

En Chile, los gobiernos desde 1959 en adelante rompieron, a petición de los EE. UU., sus relaciones con Cuba. Lo hizo el presidente Alessandri en 1958. El siguiente, Frei (1964-1970), mantuvo esta actitud, y no fue hasta la llegada de Allende al poder en 1970 cuando se restablecieron las relaciones con la Isla. Aquello enojó enormemente a los EE. UU. porque sobre todo advertía del criterio de independencia que iba a mantener la presidencia chilena, a la par que dibujaba una nueva relación de fuerzas de las izquierdas en toda Latinoamérica.

En la política interna, la presidencia Frei estuvo marcada por lo que se denominó la revolución de la libertad, que trataba de oponerse a los modelos izquierdistas de revolución, que entonces estaban en alza en todo el continente. Esta revolución de la libertad implementó políticas económicas con contenido social, favoreciendo a los sectores obreros y menos pudientes de la sociedad. No obstante, el agotamiento del modelo y el ascenso del desempleo llevaron a la Unidad Popular, encabezada por Allende, a ganar las presidenciales de septiembre de 1970. Lo hizo tras una dura campaña de intoxicación en la prensa. Alentando el miedo al «comunismo» y distorsionado la realidad de manera fantástica, los grandes medios de comunicación, todos en manos de la derecha, generaron una psicosis de guerra contra Allende que no iba a cejar hasta el golpe de Estado de 1973.

Las buenas relaciones que Allende, y la UP, tuvieron al comienzo de su mandato con los sectores más progresistas de la democracia cristiana explican que estos votasen por la designación de Allende como presidente y apoyasen conjuntamente con la UP leyes para reformar parcialmente la Constitución. El apoyo para Allende fue decisivo, porque sin ello no hubiese llegado a la presidencia. De hecho, importantes sectores, los más derechistas, propusieron la votación en favor de Alessandri, dado que el Congreso tenía la potestad de nombrar presidente a uno de los dos candidatos que más votos hubiese obtenido, siempre que la mayoría fuese relativa y no absoluta.

Este acercamiento entre los sectores progresistas de la DC y la UP no era bien visto por la derecha de la DC, ni obviamente por los EE. UU. De tal manera que, cuando un grupo de «extrema izquierda», infiltrado por la CIA, asesinó a Edmundo Pérez Zujovic, ministro del Interior del Gobierno Frei en el mandato anterior, el hecho fue aprovechado para distorsionar las relaciones entre la DC y la UP, que desde entonces se fueron alejando progresivamente.

En cualquier caso, y al margen de las relaciones interpartidarias, la derecha económica y los norteamericanos estuvieron conspirando contra 
el Gobierno de Allende desde el primer momento. Se promovieron huelgas empresariales, de las que la más conocida fue la del sector de transportes, que consiguió bloquear el comercio en el país y generó desabastecimiento en los mercados y tiendas locales, Esta huelga fue patrocinada por la CIA, que destinó dinero para pagar a los huelguistas los días perdidos de trabajo. La reacción de los sectores vinculados al Gobierno consistió en la creación de Juntas de Abastecimiento y Precios (JAP), para tratar de impedir la carencia de los productos básicos. Otro sector lanzado contra el Ejecutivo de Allende fue el de la minería del cobre. Este era estratégico para la economía chilena y se encontraba en manos de la ITT (International Telephone \& Telegraph), la empresa multinacional norteamericana que controlaba esa rama productiva. Los obreros del cobre, siendo los mejor pagados entre los proletarios del país, iniciaron, sin embargo, una huelga al objeto de dañar la economía y el prestigio de la presidencia de Allende. El sector había sido nacionalizado por el Gobierno con el acuerdo unánime del Congreso. Estos obreros fueron señalados como quintacolumnistas del golpismo, dado que todo el tiempo que duró el Gobierno de Allende se mantuvieron en pie de guerra, con manifestaciones, barricadas y cortes de carreteras, encontrando siempre refugio en el Parlamento (de mayoría derechista), así como en la Universidad Católica (también derechista). $\mathrm{Su}$ reivindicación era una subida salarial.

A pesar del clima de hostilidad permanente que tuvo que soportar Allende y de la agresividad y la psicosis creada por los medios, en las elecciones de marzo de 1973 para el Parlamento, el apoyo a la UP sube del 36\% alcanzado en 1970 hasta el 43\%. En contra de lo esperado, el resultado electoral señalaba que ganaba apoyos entre la población ${ }^{5}$.

Cuando la reacción comprendió que sus planes desestabilizadores no iban a tener efecto para derrocar al presidente, planearon el golpe militar, alternativa definitiva contra el Gobierno de Allende. Alguna intentona menor había sido ejecutada en junio, al objeto de calibrar las fuerzas y las reacciones, y en preparación del gran golpe de septiembre de 1973. El de junio consistió en sacar tanques a la calle para pulsar los ánimos. Fue controlado con Allende al frente y con Pinochet del lado constitucional de manera aparente, porque él también salió a la calle junto con Allende para contener el golpe. Sin embargo, Pinochet, junto con la CIA, estaba en los preparativos del que sería el golpe definitivo el 11 de septiembre de 1973. La oscuridad se cernió sobre el país. Una represión enorme concentró a miles de detenidos en el estadio de fútbol de Santiago. Muchos fueron asesinados. Al cantante Víctor Jara lo torturaron antes de acribillarlo. El presidente Allende murió defendiendo el palacio pre-

${ }^{5}$ Soto, Óscar, El último día de Salvador Allende, Aguilar, Madrid, 1998. Garcés, Joan, Allende y la experiencia chilena. Las armas de la política, Siglo xxı, Madrid, 2013. 
sidencial (La Moneda) el mismo día 11. Con Pinochet se iniciaron los planes económicos de la escuela de Chicago. El neoliberalismo comenzó a aplicarse en Chile con la dictadura, igual que posteriormente lo haría Argentina tras el golpe de la Junta Militar en $1976^{6}$.

${ }^{6}$ Garcés, Joan E., Soberanos e intervenidos. Estrategias globales, americanos y españoles, Siglo xxi, Madrid, 1996. 
7. LA URSS DESDE STALIN A SU BANCARROTA 



\subsection{El estalinismo y SU influenCia}

El sistema político de la Unión Soviética se consolidó tras el termidor estalinista en la década de los años treinta. Las características principales de la dictadura fueron el dominio del partido sobre el Estado y la sociedad, dándole el poder a la burocracia estatal y partidaria. La idea de Stalin prima la opción de consolidar la revolución en un solo país, frente a quienes opinaban que eso asfixiaría el proceso revolucionario. Stalin necesitaba desarrollar con urgencia las industrias como mecanismo para defender la Revolución y también para crear la transición al socialismo desde una sociedad atrasada y campesina.

La figura de Stalin se convirtió en sinónimo de socialismo y de revolución, en detrimento del debate abierto y democrático, que terminó por desaparecer de la URSS a finales de los años veinte. El culto a la personalidad del líder sustituyó a la democracia. El Estado y el partido estaban encarnados en la persona de Stalin.

Bajo la dictadura burocrática y personalista, la sociedad soviética inició la andanza de la industrialización. Tras un proceso brutal de colectivizaciones forzosas de la tierra, que generó hambrunas, muertes y represión a gran escala y las purgas de los dirigentes comunistas, que fueron asesinados por miles, Stalin se hizo con el poder absoluto. En esas condiciones políticas se acometió un proceso acelerado de crecimiento industrial que transformó toda la estructura social del país. La población industrial y urbana creció de forma exponencial, la mujer se introdujo masivamente en el mercado laboral, se acabó con el analfabetismo y se inició un despegue tecnológico muy importante.

En el plano de la economía, el estalinismo impulsó organismos centralizados para llevar adelante los planes quinquenales. Estos organismos se encargaban de fijar las magnitudes macroeconómicas y de regular el mercado, los niveles de producción, el ahorro, la inversión, el consumo, los precios y los salarios. La injerencia del Estado en la economía era total y abarcaba todas las aristas. El crecimiento industrial se apoyó originariamente en el sector agrario, que fue el que financió a la industria a través de los procesos de colectivización de las tierras y las granjas. Este sistema se basó en dos modalidades denominadas Koljós, sistema cooperativo de propiedad colectiva, y Soljós, que era una granja enteramente de propiedad estatal. 
Sobre el esfuerzo del mundo campesino se armó y edificó un sistema industrial que tuvo un rápido crecimiento y un éxito notable. Si a mediados de los años veinte la industria privada significaba el $26 \%$ del total, a mitad de la década siguiente apenas alcanzaba el 0,5\%. La industria privada en la década de los veinte se había beneficiado de la Nueva Política Económica (NEP), que tenía como uno de sus principios rectores dejar cierto margen de desarrollo a la iniciativa privada para acelerar el desarrollo de la industria. La economía en su conjunto pasó a estar reglada por planes quinquenales, en los que se estructuraban con gran detalle todos los aspectos y ponderables de la producción.

Stalin asentó su poder merced a las relaciones estrechas que tejió con la burocracia del partido y posteriormente del Estado. La burocracia soviética se convirtió en la nueva clase social dominante, no en términos de clase capitalista, sino en clave de clase dirigente asociada al poder político. Este modelo se fue consolidando desde finales de los años veinte y era ya la nueva realidad en la década de los treinta.

Tras la Guerra Mundial y el triunfo del ejército rojo contra las tropas de Hitler, la proyección internacional de Stalin y de la URSS se acrecentó, y ello ayudó a que se le considerase más internacionalmente. El inicio de la guerra fría y la configuración de polos mundiales antagónicos, junto con el agrandamiento del bloque comunista en Europa y Asia (Revolución china de 1949), dieron a Stalin una posición de fuerza renovada en el interior y el exterior.

Cuando en marzo de 1953 se anunció su muerte, millones de personas en todo el mundo quedaron conmocionadas y tristes. Las consecuencias criminales del modelo estalinista no eran conocidas de manera masiva. Solo sectores minoritarios dentro de la URSS y fuera de ella, procedentes del mundo comunista (Trotski), habían advertido sobre este asunto, pero sus voces habían caído en saco roto.

En el último año de vida de Stalin se celebró el xix Congreso del PCUS (Partido Comunista de la Unión Soviética). El dictador delegó protagonismo en dos personas muy próximas a él: Malenkov y Kruschev. Ambos dirigentes dieron los discursos de mayor relevancia. Abordaron una reestructuración del Presídium, antiguo Politburó (órgano máximo del poder político en la URSS), promoviendo la ampliación del número de miembros. No es de extrañar que Stalin les diese tal protagonismo compartido a esos dos dirigentes de la vieja guardia. Tradicionalmente, Stalin usaba este tipo de operación para fracturar el poder de quien consideraba que podría hacerle sombra, y, una vez enfrentados, liquidaba primero a uno y luego al otro. Así es como operó en las purgas de 1936-1939. En esta ocasión no iba a tener tiempo porque su muerte estaba cerca ${ }^{1}$.

\footnotetext{
${ }^{1}$ Schlögel, Karl, Terror y Utopía. Moscú en 1937, Acantilado, Barcelona, 2014.
} 


\subsection{Del dinamismo con Kruschev al estancamiento con Breznev}

La muerte de Stalin trajo aparejada una lucha por el poder entre las tres personas más cercanas a su figura. Beria, el jefe de la policía política; Malenkov, que se convirtió en primer ministro; y Kruschev, que se hizo con el control del partido. Estos dos últimos estaban en sintonía en cuanto a la necesidad de acometer reformas de importancia en el régimen. Reformas de carácter económico y otras de liberalización política. Entre las segundas, la más inmediata fue el decreto de amnistía firmado el 27 de marzo, para las condenas menores de cinco años, así como la amnistía inmediata para las madres con hijos, los ancianos, los menores de 18 años y los enfermos.

Entre los tres mejor colocados, Beria quedó último. Fue separado, arrestado y ejecutado acusado de espiar para el imperialismo. Beria había sido el brazo ejecutor de la política represiva de Stalin desde finales de los años treinta hasta su muerte. Una vez liquidado, la disputa por el poder se concentró en los dos restantes. Kruschev, que detentaba el control del partido, pudo derrotar a Malenkov, al que no mandó ejecutar, como muestra de los nuevos tiempos, sino que lo mantuvo en el Presídium hasta que lo envió a un lugar de menor relevancia en un departamento ministerial. Desde esa posición, Malenkov sostuvo contactos con Molotov y otros miembros de las altas instancias que pretendían reducir el poder y el papel central del partido. Por ello fue acusado en 1961 de hacer política antipartido y fue expulsado del PCUS ${ }^{2}$.

En tal contexto de lucha interna se celebró el xx Congreso del PCUS, que finalmente iba a ser determinante para que Kruschev se hiciera con todo el poder y lo detentase desde entonces hasta 1964. La época de Kruschev tuvo algunos episodios muy relevantes para la historia de la URSS y del mundo. Internamente significó una tímida liberalización, en el sentido de que no hubo más ejecuciones derivadas de paranoias personalistas al estilo de Stalin, y en la arena internacional se produjo un distanciamiento de China desde finales de 1956 y un aumento de las tensiones con los EE. UU. en torno al asunto de Cuba. También la URSS jugó un destacado papel en ese entonces en favor de las descolonizaciones de los pueblos asiáticos y africanos.

En el plano interno, el acontecimiento que marcó para siempre la década de Kruschev fue su «informe secreto», en el xx Congreso del PCUS. El informe fue una verdadera bomba en el mundo comunista dentro y fuera de la URSS. Se desvelaron todas las atrocidades del periodo estalinista, se denunciaron los millones de muertes producidas por la dictadura brutal, se criticó el culto a la

${ }^{2}$ Estruch, Joan, «La muerte de Stalin y la lucha por la sucesión», en Historia 16, Siglo Xx. Historia Universal 27, Madrid, 1983, pp. 55-75. Lewin, Moshe, El siglo soviético, Crítica, Barcelona, 2006. 
personalidad y se desmontó todo el mito construido hasta entonces sobre el dictador. Aquello conmocionó al mundo y conllevó dentro del país importantes reestructuraciones de los muchos departamentos administrativos del Estado y del partido. Los crímenes de Stalin pasaron a formar parte del imaginario sobre el sistema soviético desde entonces.

Kruschev trató de impulsar la estancada agricultura soviética y acelerar el proceso industrializador para permitir al país dar un nuevo salto adelante. La URSS seguía avanzando con paso firme hacia un modelo netamente urbano y recuperaba por fin el equilibrio demográfico que se había visto mermado por los veinte millones de muertos producidos por la invasión alemana. Para la política internacional, el nuevo dirigente estimaba que los dos sistemas mundiales (capitalismo y socialismo) debían solventar sus diferencias por la vía de la competencia pacífica; a la idea se le dio el nombre de emulación pacífica. Kruschev pensaba que la superioridad del modelo socioeconómico de su país terminaría por imponerse al capitalismo norteamericano.

La política exterior estuvo marcada por los problemas dentro de su bloque, sobre todo en 1956 con Hungría y, a partir del xx Congreso, con China. En cuanto a Hungría, el problema vino de la revuelta obrera que se produjo en ese país, en el que las masas pedían reformas urgentes del sistema económico y político y la recuperación de la soberanía plena, porque entonces todos los países adscritos a los bloques solo disponían de soberanía limitada, es decir, su acción era permitida mientras no chocara con los intereses de las superpotencias. El golpe griego fue un ejemplo en el Oeste, y la intervención militar en Hungría en 1956, por parte del ejército rojo, fue un ejemplo en el Este.

El conflicto con China estuvo motivado por los desacuerdos de Pekín con las críticas vertidas hacia Stalin en el xx Congreso. China estaba inserta además en un proceso prerrevolucionario que estallaría unos años después, conocido con el nombre de revolución cultural proletaria, en la que se hizo una dura crítica a la burocracia socialista y se llevó a cabo una política de purgas y eliminación masiva de cuadros de la Administración y del partido. Los comunistas chinos pensaban que en la URSS la burocracia había tomado el poder y convertía al país en un modelo reformista y socialimperialista. Desde 1960 las relaciones entre los dos grandes países comunistas quedaron congeladas y el movimiento comunista internacional se fracturó, aliándose algunos países y partidos comunistas con los chinos y otros con los soviéticos.

Durante la década de Kruschev, los soviéticos se adelantaron brevemente en la carrera espacial a los EE. UU.: en 1957 enviaron el primer satélite al espacio exterior, y en 1961, al primer hombre al espacio (Yuri Gagarin). Aquello produjo un verdadero quebradero de cabeza en los EE. UU., que, en su paranoia anticomunista, veían cerca el final de su mundo capitalista y su pronta caída bajo el control de los malvados rojos.

En 1962 un episodio de tensión extrema ocurrió en Cuba. Después de sucesivas agresiones de la CIA hacia la Isla y de las políticas de bloqueo económico, se 
intentó de nuevo invadirla, pero ahora con soldados norteamericanos para evitar un nuevo fracaso como el de Bahía Cochinos. Fue así como se montó la Operación Mangosta, pero esta fue detectada por los servicios secretos soviéticos, que informaron a Fidel Castro. Aquello conllevó la instalación de misiles nucleares soviéticos en Cuba y los trece días posteriores de tensión extrema, que colocaron al mundo al borde de la guerra atómica. En conversaciones de última hora entre Kennedy y Kruschev, los misiles son retirados y se establecen nuevas normas de cara al futuro para evitar tensiones como las vividas en las semanas precedentes. Entre los acuerdos tomados se decidió el establecimiento de un teléfono directo entre las dos presidencias. Se llamó el teléfono rojo.

A lo largo de la década se fueron buscando maneras de contener la escalada nuclear. A pesar de las grandes palabras llenas de buenas intenciones, en muchos casos la propia dinámica real desmentía lo acordado. A finales de la década de los sesenta, los EE. UU. tenían desplegados 500 misiles intercontinentales frente a 100 de los soviéticos.

En cuanto a las descolonizaciones, los soviéticos jugaron un papel de facilitadores. Estaban interesados en debilitar el flanco colonialista que hasta entonces se apoyaba, sobre todo, en los grandes dominios anglo-franceses en el mundo. Así que, cuando llegó la hora de las masivas independencias en África en el año 1960, la URSS fue un actor muy activo tanto en la ONU como en las relaciones multilaterales para que los africanos accedieran a las independencias. Debilitar el dominio europeo en el mundo era también, en cierta forma, ganar batallas de la guerra fría ${ }^{3}$.

Destituido Kruschev (1964), la URSS entró en un periodo de estancamiento paulatino, y aunque la tendencia se mantuvo en las décadas siguientes, sin embargo el país siguió creciendo, haciéndose más urbano y modernizándose completamente. El crecimiento urbano trajo aparejado un envejecimiento relativo de la población y una concentración demográfica en las grandes ciudades que dio origen a desequilibrios económicos y poblacionales en estas décadas. El desajuste venía además motivado por la elección estratégica de favorecer la economía y la tecnología vinculada al ejército, que luego no se traducía en bienes de equipo y servicios para la economía y el consumo civil. Si bien los EE. UU. tuvieron la habilidad de transferir a la economía civil los avances tecnológicos en el terreno militar (computación, robótica), en la URSS se mantuvo una separación muy estricta de ambas esferas. Esto imposibilitó un crecimiento competitivo de la economía soviética y detrajo recursos para la producción de bienes básicos para el mercado socialista, lo que creó desabastecimiento y escasez en los mercados civiles. Esta economía lastrada por el burocratismo y la falta de estímulos al desarrollo

3 Taubman, William, Kruschev. El hombre y su época, La esfera de los libros, Madrid, 2005. Deutscher, Isaac, La década de Jrushov, Alianza, Madrid, 1971. 
generó un sistema estancado que iba perdiendo paulatinamente el desafío en la competencia económica frente al capitalismo norteamericano. Además de ello, la falta de libertades individuales y colectivas, tanto en el plano sindical como en el político y en el cultural, fue generando una sociedad apática y poco proclive a comprometerse con el desarrollo del país.

En el plano de la carrera de armamentos, que es donde la URSS daba la sensación de competir con el coloso occidental, la era de Breznev estuvo marcada por algunos intentos de controlar el asunto. En 1968 la URSS, EE. UU. y Gran Bretaña firmaron el Tratado de no Proliferación de Armas Atómicas, al que, sin embargo, no se sumaron ni Francia ni China. En 1969 se iniciaron conversaciones para la limitación de armas estratégicas, conocidas con el acrónimo SALT (Strategic Arms Limitation Talks), que llegaron a buen puerto y cuyos acuerdos los firmaron las dos superpotencias. SALT ponía límite a la fabricación de armas estratégicas y fijaba una cantidad a poseer por las potencias. De esta manera, los firmantes se comprometían a contener la fabricación de misiles intercontinentales, bien tuviesen su base en tierra o en submarinos. Estos acuerdos fueron firmados en 1972 y tenían como eje básico de su filosofía la prohibición de fabricar armas defensivas antimisiles. Así garantizaban que si comenzaba la guerra, ambos contendientes quedarían destruidos, de lo cual deducían que por ello nadie estaría interesado en comenzar la guerra atómica. A este principio se le denominó equilibrio del terror, o DMA (Destrucción Mutua Asegurada).

\subsection{Perestroika y glasnost}

A la muerte de Breznev en 1982, dos líderes efímeros coparon la presidencia del país. Andropov y Chernenko eran sus nombres. La vieja guardia del partido y del Estado. Daba la impresión de que la URSS era un sistema dominado por la gerontocracia, y así lo parecían trasmitir ellos mismos. En ese interregno de tres años, en los que hubo tres funerales de Estado consecutivos, el país parecía no poder salir de esa parálisis institucional.

Fue en 1985 cuando una nueva figura llega al poder. Era un hombre de otra generación de líderes más jóvenes y que parecía portador de ideas reformistas de calado, ante la evidencia del profundo estancamiento en que estaba sumida la economía y la sociedad soviética. Este nuevo líder era Gorbachov. Porta un plan reformista que se apoyaba en dos ideas fuerzas: perestroika y glasnost (reestructuración y transparencia).

Cuando Gorbachov accedió a la secretaría general del PCUS en marzo de 1985, se encontró con una economía al borde de la bancarrota, asumiendo gastos inabordables, como eran la carrera de armamentos y la guerra en Afganistán, y una sociedad descreída del modelo socialista. La URSS había agotado su crédito ante la población, porque no resolvía sus problemas más cotidianos ni podía permitirse seguir compitiendo con EE. UU. en una carrera espacial y militar que 
desbordaba por completo sus capacidades. Gorbachov asumió muy pronto ambas realidades y de ahí el impulso de sus reformas, que en un principio querían ser reformas del sistema soviético, pero que en cinco años terminaron demoliéndolo. El sistema no era reformable.

El desafío lanzado por la Administración Reagan con la Iniciativa de Defensa Estratégica (IDE) les puso la puntilla a los soviéticos en cuanto a las posibilidades de seguir compitiendo con los EE. UU. En ese entonces la URSS gastaba como promedio de su presupuesto anual un $20 \%$ en armamentos, mientras la economía hacía agua por todas partes y, en especial, en cuanto al abastecimiento de los mercados y tiendas de productos de consumo para la población. Gorbachov asumió la necesidad de facilitar un acercamiento a los EE. UU. para negociar políticas de desarme y de ahorro del gasto en esas partidas. Desde el primer encuentro que mantuvo con Reagan, en noviembre de 1985, en Ginebra, así se lo hizo saber.

La nueva política soviética requería nuevos principios en las relaciones internacionales. Se sustituyó al perenne ministro del Exterior (Gromiko), que venía siéndolo desde 1957, por Shevernadze, quien compartía con Gorbachov la intención de llevar adelante las reformas planeadas.

El líder soviético planteó en el xxvir Congreso del Partido, celebrado en 1986, las claves de su nuevo pensamiento político. Habló de la necesaria interdependencia en el mundo y, por tanto, propuso dejar atrás la lógica de la guerra fría y la carrera de armamentos. Opinaba que eso tenía que ser sustituido por la cooperación y el buen entendimiento en las relaciones internacionales. De esta manera el dirigente soviético comenzó a advertir a sus propios aliados sobre su intención de replegarse de cada uno de sus países, a la vez que los conminaba a desarrollar reformas en el mismo sentido en que la URSS proponía hacerlo.

En tal contexto se produjo la catástrofe nuclear en la central de Chernobyl (Ucrania) en abril de 1986. La explosión y el posterior escape radiactivo, muy superior a las bombas de Hiroshima y Nagasaki, alertó a la URSS de las terribles deficiencias que corroían al sistema completamente. La dirigencia soviética no se enteró del accidente hasta algunos días después, y las medidas que se tomaron eran improvisadas, porque no se sabía bien qué hacer, y tampoco se tenían recursos ni medios para abordar un plan seguro y completo. Se tardó en evacuar a la población (500.000) y de manera apresurada enviaron personal militar para tratar de contener el escape. Los soldados iban sin protección y, en consecuencia, decenas de miles estuvieron expuestos a los agentes contaminantes y al cáncer.

Además del problema en Chernobyl, los soviéticos se encontraban empantanados en una guerra en Afganistán desde 1979. En dicho conflicto la estabilización de los bandos y la imposibilidad del ejército rojo para ganar la contienda, junto con la voluntad de los mujaidines afganos de continuar una guerra de desgaste contra los soviéticos, convencieron a Gorbachov de la necesidad de la retirada. Los mujaidines encontraron el apoyo financiero y armamentístico de los norteamericanos y de los saudíes. Para los EE. UU. Afganistán significó la ocasión de provocarles a los soviéticos su propio Vietnam. El apoyo sistemático de Washing- 
ton a los mujaidines afganos terminará dando sus frutos con la retirada soviética en 1989, pero tendría con el transcurrir del tiempo el efecto de promocionar el terrorismo islámico contra los propios estadounidenses, cuando se fundó Al Qaeda y Bin Laden — sin enemigo soviético que atacar - apuntó hacia los EE. UU.

Tanto la guerra de Afganistán, y sus nefastas consecuencias para los soldados soviéticos, como los efectos de Chernobyl fueron conocidos por la ciudadanía de la URSS gracias a la política de glasnost impulsada por Gorbachov, porque con la transparencia, por primera vez desde los años veinte, se volvió a permitir la libertad de prensa y de opinión. Esto hizo posible que el disenso con el sistema se tratase abiertamente a nivel informativo, aunque aún no existiesen partidos políticos para canalizar los distintos puntos de vista.

La política internacional iba a estar marcada por una serie de acuerdos y desacuerdos en torno al control de armamentos. Tras la primera cumbre de 1985 entre las dos superpotencias, se produjo una segunda en Reikiavik en octubre de 1986, sin que se llegara a acuerdos concretos. En diciembre de 1987 se firmó el Tratado de Washington, que establecía la destrucción de armas nucleares de corto alcance, con lo que se hacía referencia a los misiles soviéticos SS-20 y los misiles Pershing y Crucero de la OTAN. En ambos casos los misiles amenazan a Europa, que era el escenario de la hipotética contienda con este tipo de armas de medio alcance.

Al año siguiente se entablaron las negociaciones START (Strategic Arms Reduction Talks). Con este tratado se quería conseguir la reducción de armas estratégicas de largo alcance. Estos acuerdos fueron firmados en 1991 por Gorbachov en sus últimos meses y por Bush (padre), que era ahora el presidente norteamericano. Este acuerdo puso punto final a la guerra fría.

En 1988 el dirigente soviético había anunciado la retirada de medio millón de soldados de Europa oriental. El anuncio se hizo en la sede de la ONU y tenía carácter unilateral. Con estos 500.000 soldados se desmantelaban las bases militares de la URSS en el este de Europa. Tras el gesto de Gorbachov en 1990, la OTAN y el Pacto de Varsovia mantuvieron conversaciones en Ottawa, en las que llegaron al acuerdo de reducir las fuerzas convencionales en el continente europeo.

Las iniciativas soviéticas estaban llevando a un nuevo reajuste de fuerzas en el globo, porque la URSS, además, advirtió a sus socios que se retiraría de sus distintos países y que cada uno debería resolver sus problemas sin injerencias externas. Rompía así la doctrina de la soberanía limitada y daba total independencia a los países del Este. La URSS, igualmente, se desembarazó de todos sus compromisos con los países del Tercer Mundo y, acorde con ello, su repliegue económico se notó de manera inmediata en Cuba, Nicaragua, Etiopía, Eritrea y Camboya, entre otros.

En Europa oriental su retirada también fue efectiva y total, dando pie a que los regímenes comunistas de los países del bloque oriental se viniesen abajo. El proceso lo inició Polonia, país donde las tensiones entre el sindicato Solidaridady 
el Gobierno venían acumulándose desde hacía algunos años. En 1989 se reconoce de manera legal al sindicato y con ello el pluripartidismo, iniciándose un proceso de reforma hacia la democracia. Los comunistas perdieron las elecciones y Lech Walesa, dirigente de Solidaridad, fue elegido presidente en 1990.

Le siguió por ese mismo camino Hungría, que ya había iniciado un proceso de reforma encabezado por los mismos comunistas. En 1989 habían logrado establecer un régimen pluripartidista, disolvieron el partido, elaboraron una nueva Constitución y afrontaron elecciones en 1990, que dieron el triunfo a un conglomerado de fuerzas anticomunistas denominadas Fidesz (Fiatal Demokraták Szövetsége, Alianza de Jóvenes Demócratas).

La RDA (República Democrática Alemana) era el principal escollo en todo este asunto. El muro pasaba por Berlín, y nadie quería una Alemania unificada nuevamente en el centro de Europa. No obstante, cuando los húngaros abrieron sus fronteras, los alemanes orientales las traspasaron por miles en dirección a la RFA (República Federal de Alemania). Los movimientos reformistas en las naciones aliadas de la URSS se aceleraron cuando el ministro de Asuntos Exteriores declaró en público que no se iba a interferir en la política interna de los países de la Europa oriental. Esas declaraciones fueron realizadas en octubre de 1989. Y dos días después, Gorbachov condenó explícitamente la doctrina Breznev (soberanía limitada). En la RDA el viejo y ortodoxo Honnecker fue sustituido al frente del Gobierno por Egon Krenz, quien abrió el muro de Berlín el 9 de noviembre de 1989. Con ello puso fin a la separación de Alemania y de Europa, y preparaba el proceso de unificación alemán del año siguiente ${ }^{4}$.

La decisión de la unificación de Alemania se tomó en una reunión llamada Acuerdo 4+2 (URSS, EE. UU. Francia, Gran Bretaña, RFA y RDA), celebrada en octubre de 1990. Con esa firma, los aliados de la Segunda Guerra Mundial y Alemania daban inicio a una nueva era y cerraban definitivamente las consecuencias de aquel gran conflicto bélico. El acuerdo al que accedió la URSS, que luego se ha incumplido por parte de los países occidentales, conllevaba la limitación del poder militar alemán, la no presencia de tropas de la OTAN en la antigua RDA, así como en los países del antiguo Pacto de Varsovia, y ayudas económicas para la URSS, al objeto de facilitarle el proceso de reformas en que estaba inmersa ${ }^{5}$.

${ }^{4}$ Berend, Ivan T., Europa desde 1980, FCE, México, 2013.

${ }^{5}$ Lewin, Moshe, El siglo soviético, Crítica, Barcelona, 2006. 


\subsection{El FinAL DE LA URSS y EL RETORNO DEL CAPITALISMO}

Con la desmembración de Europa oriental comenzó también la de la URSS, aunque entonces nadie lo sospechaba, porque el país era contemplado como una fortaleza sólida y a prueba de hecatombes inauditas, como había demostrado en la Segunda Guerra Mundial. Sin embargo, la historia reveló que esa visión era errada. La URSS era un imperio con pies de barro en 1990.

La crisis económica sacó a la luz las serias deficiencias del sistema de economía central planificada. Los flamantes medios de comunicación relataban abiertamente el sistema de corruptelas y la incompetencia que atesoraban los directores de la economía, bien fuesen directores de fábrica, de complejos industriales o en los propios ministerios. El sistema estaba corrompido en toda su estructura, desde la base al vértice. Además de ello, los movimientos nacionalistas en el interior de la Unión precipitaron el desmontaje. Fueron las tres repúblicas bálticas, incorporadas durante la Segunda Guerra Mundial, las primeras en separarse de manera unilateral del conjunto de la Unión. Las repúblicas habían sido anexionadas tras el acuerdo Molotov-Ribbentrop en los prolegómenos de la guerra. Luego estuvieron ocupadas por los nazis hasta 1945, y tras la derrota alemana se incorporaron a la URSS.

Las cuestiones secesionistas también afectaron a las repúblicas del Cáucaso, que a su vez estaban enfrascadas en conflictos armados entre armenios y azerís, en torno a Nagorgo-Karabaj desde 1988. Inmediatamente, el conflicto se extendió a Chechenia, y otras repúblicas del sur —Georgia, Turkmenistán, Uzbequistán, Turkestán, Azerbayán, Kazajistán, Takiyistán, Kirguistán y Armenia— reclamaron su independencia. También lo hizo Ucrania, que era la segunda mayor República de la URSS tras la Federación Rusa, y Bielorrusia, que era la parte más occidental del país, junto con Moldavia.

El golpe definitivo vino de la propia República rusa. Cuando Gorbachov propuso la renuncia al monopolio del poder político por parte del PCUS y convocó elecciones parciales pluripartidistas, se encontró con el ascenso de las fuerzas independentistas en los territorios periféricos, sobre todo en los países bálticos; se abría así la espita de la desintegración. Además de ello, el doble poder existente en Moscú tras la elección de Yeltsin como presidente del Parlamento ruso socavó la posición de Gorbachov, que ahora presidía formalmente un país sobre el que no tenía control. Las medidas impulsadas por Yeltsin debilitaron la posición del entonces rival Gorbachov, que vio cómo su ministro reformista de Exteriores abandonaba el Ministerio en protesta por los intentos de los conservadores de dar un golpe de Estado.

Gorbachov intentó a la desesperada recuperar la iniciativa y propuso negociar un nuevo Tratado de la Unión, que ahora no contentaba a los secesionistas, los cuales querían la independencia, ni a los conservadores del PCUS, que leyeron la pérdida de control del secretario general como el fin de sus días. Intentaron dar un golpe de fuerza y secuestraron a Gorbachov durante unos días en Crimea, 
en agosto de 1991. Yeltsin aprovechó la ocasión para dar un golpe de Estado en Moscú y hacerse con el poder. Yeltsin anunció que Rusia se iba de la Unión y estableció de facto un nuevo país, en el que Rusia heredaba los compromisos y las posiciones internacionales de la URSS. A partir de ahí todas las demás repúblicas siguieron el ejemplo. Un último intento hecho desde Moscú por mantener unidas a las repúblicas fue la creación de la Confederación de Estados Independientes, experimento de efímera vida. Finalmente, Gorbachov presentó su dimisión formal como presidente de la URSS el 25 de diciembre de 1991.

La nueva elite capitalista, que procedía toda de las filas de los comunistas de ayer, se hizo con las palancas de la economía y creó un sistema oligárquico y de enriquecimiento acelerado, favorecido por el nuevo Estado, con la intención de crear rápidamente un proceso de acumulación capitalista. Los nuevos ricos y el aparato de Estado en época de Yeltsin aplicaron planes de choque para liberalizar la economía. Dichas reformas se hicieron de acuerdo a las indicaciones que recomendaron el FMI y el BM, en la lógica de las terapias privatizadoras que se sugerían a los países del sur ${ }^{6}$. Se logró con ello destruir por completo la base de la economía estatal, tanto de los sectores sanos como de los inservibles. Las medidas de choque generaron grandes bolsas de pobreza y miseria, así como un importante rol de la economía criminal y del tráfico de bienes y personas. De esta manera se paralizó durante más de una década el papel internacional de Rusia, que fue expulsada paulatinamente de sus posiciones estratégicas en las antiguas repúblicas del Cáucaso y en otros territorios más alejados como Oriente Medio. Los ingentes recursos naturales del país y su estructura fabril fueron tomados por asalto por los agentes que estaban alrededor del poder político yeltsiniano.

Este capitalismo sin control político, con un Parlamento devaluado y una presidencia en manos de un declarado alcohólico, sumió a Rusia en una larga década de recesión y de depresión económica y psicológica. Ello daría lugar al ascenso meteórico de Putin en 2000, que pasó a ganar las elecciones presidenciales de ese año con un $53 \%$ de apoyo electoral. Putin había hecho su carrera hasta entonces en los servicios secretos (KGB), de los que fue nombrado director cuando pasaron a denominarse Servicio Federal de Seguridad, en $1998^{7}$.

${ }^{6}$ SÁnChez Andrés, Antonio, «La economía rusa: una década de transición», $C I D O B$ d'Afers Internacionals, n. ${ }^{\circ}$ 59, 2002, pp. 53-72.

${ }^{7}$ Prieto, Carlos, De la URSS a Rusia, Tres décadas de experiencias y observaciones de un testigo, FCE, México, 2014. Khanna, Parag, El segundo mundo: Imperios e influencia en el nuevo orden mundial, Paidós, Barcelona, 2008. 



\section{LA CONTRARREVOLUCIÓN DE LOS OCHENTA ES INTERNACIONAL}



La década de los ochenta comenzó con el ascenso al poder de dos líderes que tenían un claro proyecto de terminar con el Estado del bienestar. Uno era Reagan, elegido presidente de los EE. UU. en enero de 1981, y la otra era Thatcher, que había alcanzado la presidencia del Gobierno británico en mayo de 1979. Estos dos dirigentes iniciaron lo que posteriormente se denominó la revolución neoconservadora.

La «revolución» se extendió a la mayoría de los países del planeta, en especial a los del primer mundo, comenzando por contagiarse entre los miembros de la Commonwealth Nueva Zelanda y Australia. Luego su influjo alcanza al corazón de Europa, que con Francia a la cabeza empezó a asumir paulatinamente este giro a la derecha en el conjunto de sus políticas económicas. También España, bajo gobierno socialdemócrata (PSOE), puso en práctica buena parte de las recetas neoconservadoras. Lo propio hicieron Alemania y Canadá y, fuera del primer mundo, México, Argentina, Brasil, Venezuela, Colombia y muchos más. Especial atención reclama a este respecto China: allí, bajo la dirección del Partido Comunista de China, se implementan las políticas neoliberales, primero tímidamente en las «zonas especiales» y, posteriormente, en el conjunto del país, lo que a la postre ha convertido al gigante asiático en uno de los pilares básicos de la globalización neoliberal ${ }^{1}$.

La influencia de estas políticas trascendió el mandato de los dirigentes que las inauguraron. En las décadas siguientes se convirtieron en señas de identidad y de hacer político y dieron paso a lo que hoy se denomina globalización neoliberal.

El pensamiento neoliberal se fue fraguando desde el mismo comienzo de la posguerra mundial. Frente a la extensión del comunismo por Europa y Asia, y el desarrollo de las guerrillas en Latinoamérica y África, los ideólogos del pensamiento liberal comenzaron a tejer una teoría que contraponer al entonces poderoso pensamiento socialista. Friedrich Hayek se mostró partidario de un

1 Zivang, Zhao, Prisionero del Estado. El diario clandestino de un Primer Ministro, Algón, Granada, 2011. Ríos, Xulio, China pide paso. De Hu Jintao a Xi Jinping, Icaria, Barcelona, 2012. Galván Fernández, Francisco, El mundo reciente, 1985-2000, Idea, Tenerife, 2006. 
Estado reducido a la mínima expresión, y quería terminar con su concepción providencialista. En su análisis, el Estado debía abstenerse de inmiscuirse en los asuntos económicos. Hayek era un defensor de la creencia de que el mercado se autorregula, de manera espontánea. Para este economista, el Estado keynesiano había caído bajo el control de las clases medias y ejecutaba políticas fiscales en su beneficio, lo cual condenaba; por contra, defendía la idea de que el Estado no debía entrometerse en la redistribución de la riqueza social. Sus ideas centrales consistían en «desregular, privatizar, limitar la democracia, suprimir las subvenciones para la vivienda y el control de los alquileres, disminuir los seguros de desempleo, reducir los gastos de la seguridad social [...], quebrar el poder sindical» ${ }^{2}$.

Estos fueron los caballos de batalla de los pensadores que anticiparon el neoliberalismo, y que manifestaron una y otra vez en las universidades, revistas y medios de comunicación de los países más desarrollados. Fueron refrendados con premios Nobel y generosas financiaciones para sus estudios y divulgaciones.

Junto a F. Hayek, otro eminente economista neoliberal fue Milton Friedman, quien opinaba que la superioridad del capitalismo y su buen funcionamiento se producen porque los individuos, en la búsqueda de su propio interés, ayudan al desarrollo de la sociedad. Para estos pensadores lo social no está en el centro, sino que el individuo es quien ocupa esta posición. Friedman deja para el Estado la función de control y la represora: con su monopolio de la violencia debe garantizar la protección de la libertad frente a los enemigos internos y externos. El Estado está para garantizar que se cumplan los contratos privados y fomentar la competencia entre los individuos y las empresas privadas entre sí.

Estas teorías fueron ensayadas en Chile bajo Pinochet, al que el propio Friedman visitó en 1975. Muchos de sus alumnos, conocidos como la Escuela de Chicago, se emplearon como asesores económicos del dictador chileno. Luego, tras la llegada de los conservadores y los republicanos a los gobiernos de Gran Bretaña y los EE.UU., este pensamiento cobró dimensión mundial y el planeta giró empujado por sus teorías, las cuales fueron relanzadas desde la política tras el llamado Consenso de Washington, al objeto de que fuesen exportadas a todo al globo. Las ideas del «consenso» fueron resumidas por un responsable norteamericano del Banco Mundial cuando señaló sus puntos claves, que resumimos en los siguientes: disciplina con el déficit público, redefinición de las prioridades del gasto, reforma fiscal, liberalización de las tasas de interés, adaptación de las tasas de cambio, liberalización de los intercambios comerciales internacionales y de las inversiones extranjeras, privatización de las empresas públicas, desregulación de los mercados, supresión de las barreras aduaneras y protección de los

2 Ramonet, Ignacio, La catástrofe perfecta, Público, Madrid, 2010, p. 33. Hayek, Friedrich A., Camino de servidumbre, Alianza, Madrid, 1978 (1944). 
derechos de propiedad ${ }^{3}$. Estos llamados principios del Consenso de Washington serían luego la base para la creación en 1995 de la Organización Mundial del Comercio (OMC), que, junto con el Fondo Monetario Internacional (FMI) y el Banco Mundial (BM), se convertirían en las instituciones claves de la globalización neoliberal.

\subsection{Neoconservadurismo en EE. UU. y Gran Bretaña}

En estos dos países se inició el neoliberalismo global. Estas políticas fueron acompañadas de una propuesta conservadora en el orden moral. Se promocionó la religión, la crítica del feminismo, el sexismo y, en general, se fomentaron los valores de la tradición conservadora.

La acción de gobierno se encaminó, al menos teóricamente, a debilitar las estructuras del Estado. Se criticaba que había crecido mucho en las décadas anteriores y que esa gran burocracia lastraba el crecimiento económico, atesorando buena parte de los recursos del país. No parece que esto haya sido cierto, porque si bien el Estado redujo los presupuestos destinados a las políticas sociales, aumentó los gastos dedicados a engrosar la policía, el ejército, el armamento y otros vinculados con la represión y la preparación para la guerra. En los EE. UU. el presupuesto destinado a la IDE (guerra de las galaxias) fue espectacular. Los datos publicados para el caso británico señalaban que el porcentaje de mano de obra que trabajaba directamente para el Gobierno constituía en 1985 el 21,7\%, ligeramente superior a 1979 , cuando estaba en un $21,2 \% »^{4}$.

Las ideas claves del pensamiento neoliberal se asentaron sobre la sacralización del mercado como un mecanismo óptimo para la creación de la riqueza, y como pieza clave del mundo occidental. Piensan que el mercado está constituido por individuos que de manera aislada operan en él, de ahí que la idea central del proyecto pasase por hacer propietarios de sus viviendas a los asalariados medios y bajos, dado que era el único recurso de mercado para la mayoría, y reforzar con ello la sensación de triunfo individual.

La manera en que los neoliberales entienden el mercado y al individuo hace que la búsqueda de la maximización del beneficio individual sea la fuerza motora del progreso. Se denuesta al Estado por su afán regulador y en contrapartida se apoya la autorregulación del propio mercado sin interferencia política. Los neoliberales defendieron la idea de que la historia había llegado a su final, y que las sociedades humanas no iban a encontrar un modelo de superación

\footnotetext{
${ }^{3}$ RAmOnet, La catástrofe...

${ }^{4}$ Miliband, Ralph, Panitch, Leo y Saville, John, El neoconservadurismo en Gran Bretaña y Estados Unidos. Retórica y realidad, Alfons el Magnanim, Valencia, 1992, p. 12.
} 
del liberalismo económico y político. Desde esta perspectiva se consolidó una visión reduccionista y dogmática sobre tales principios, que llevó a un aumento de los conflictos militares de manera directa. El dogmatismo neoliberal ha sido una fábrica de guerras. Los británicos entraron en guerra contra Argentina por el control de las Islas Malvinas (1982) y los EE. UU. comenzaron una serie de operaciones de intervención militar en el continente americano. Atacaron la isla de Granada y Nicaragua, desarrollaron operaciones encubiertas en Afganistán e Irán, impulsaron el proyecto de guerra espacial. El nuevo intervencionismo norteamericano venía a terminar con el complejo de potencia herida que había sufrido tras la derrota en Vietnam.

En la política interna se llevó a cabo una reducción drástica de los presupuestos sociales, recortando el acceso a la seguridad social, las ayudas a los veteranos de guerra, a los agricultores, en la educación y en otras ramas de la Administración no prioritarias para esta ideología. Paralelamente, la política económica, redefiniendo las prioridades estratégicas en muchos sectores, promocionó las deslocalizaciones empresariales e industriales, primero en el interior y posteriormente hacia terceros países. Las consecuencias de ello fueron una pérdida del tejido industrial, el necesario aumento de las importaciones y la especialización en los sectores financieros e inmobiliarios. Las deslocalizaciones buscaban países con mano de obra barata. La hallaron en México, Guatemala y El Salvador, donde se instalaron muchas empresas del sector textil, y en China y otros países del sudeste asiático, a donde fueron desplazadas todo tipo de industrias. Las políticas fiscales tuvieron un marcado carácter regresivo, aplicando menos imposición a los que más tienen y más a los que menos poseen. En relación con las políticas sociales y de derechos de los trabajadores, en el caso de los EE. UU. el Gobierno trató de deslegitimar a los sindicatos, y derrotarlos allí en donde el desafío pasara a mayores, como sucedió con la huelga de controladores aéreos (1981). En el caso británico se hizo lo propio con los mineros (1984-1985).

Las desregulaciones en la economía trajeron una oleada enorme de movimientos especulativos, que dispararon los casos de corrupción de manera alarmante para la credibilidad del sistema democrático y para el propio sostenimiento del modelo neoliberal. Los capitales que ahora no iban a engrosar el capital productivo, porque este se había deslocalizado en el extranjero, se dedicaron de manera ociosa a la especulación financiera y a la creación de dinero de la nada. Este tipo de economía basada en la apuesta especulativa produjo un agujero de 125.000 millones de dólares en las cajas de ahorro de los EE. UU., que hubo de reponer el Estado durante el mandato de Bush (padre) en 19895. George H.W. Bush había sido el vicepresidente de Reagan durante los dos mandatos anteriores, con lo que su responsabilidad en este asunto era manifiesta.

\footnotetext{
${ }^{5}$ Fontana, Por el bien..., p. 618.
} 
En la experiencia británica, la primera ministra detrajo el poder de las instancias locales y de los organismos descentralizados, que hasta entonces lo disfrutaban. Las recondujo hacia organismos paraestatales que estaban bajo el control de su propio Gobierno. La Dama de Hierro llevó a cabo un plan de privatización masiva de las riquezas públicas, vendiendo las minas de carbón, cuando no cerrándolas. «El gas, la electricidad, los ferrocarriles, las líneas aéreas, los astilleros, centrales nucleares, petróleo, banca, navegación se pusieron a la venta ${ }^{6}$. También se llevaron a cabo privatizaciones en la sanidad y la educación. Todo ello generó un aumento considerable de los empleos precarios y la práctica desaparición de la histórica clase trabajadora inglesa, compuesta de trabajadores fijos y derechos consolidados. Tal clase fue sustituida por un ascenso espectacular del precariado, caracterizado por los contratos temporales, de bajos salarios y sin profesión fija.

Con todo este tipo de reformas la democracia se vio fuertemente lastrada, porque uno de los actores del marco democrático había perdido su referencia política, como puso de manifiesto el nacimiento del nuevo laborismo y sus políticas de continuidad neoconservadora. Este hecho vendría a corroborar la idea de que los neoliberales atesoran «profundas sospechas hacia la democracia» ${ }^{7}$.

\subsection{RECONVERSIÓN INDUSTRIAL, PRIVATIZACIONES Y SINDICALISMO EN ESPAÑA}

En España el PSOE había llegado al poder en octubre de 1982, conquistando una holgada mayoría absoluta que le proporcionaron los más de diez millones de ciudadanos que lo votaron. Se ha interpretado que con la llegada del PSOE al Gobierno se cierra el ciclo de la transición abierto con la muerte del dictador. No obstante, los socialistas tuvieron que hacer frente a golpistas, que permanecían insertos en la estructura militar y policial. Era urgente que la incipiente estabilidad institucional lograda tras la derrota de los golpistas en 1981 y el triunfo del PSOE se viese reforzada con la entrada en el Mercado Común Europeo y con la ratificación de la permanencia en la OTAN, con lo que este partido se desdecía de su posición previa, que era contraria a mantener a España en dicha alianza militar.

España debía hacer los deberes exigidos por los nuevos tiempos neoliberales. Así que los gobiernos socialistas emprendieron la tarea de ajustar el capitalismo español a las modas internacionales, y ello pasaba por una reconversión de la estructura industrial y minera, por una reforma igualmente profunda del sector primario para adaptarlo a las exigencias de la PAC (Política Agraria Común),

${ }^{6}$ Sanmartín Barros, Israel, «La new right en los años 80 y 90», HAOL, n. ${ }^{\circ}$ 1, 2003, pp. 39-53, p. 46.

7 Harvey, David, Breve historia del neoliberalismo, Akal, Madrid, 2007, p. 75. 
donde Francia llevaba la voz cantante, impulsar la concentración y privatización de la banca y desregular convenientemente el mercado laboral.

La reconversión industrial tenía como objetivo abaratar el trabajo y aumentar la tecnificación, al objeto de competir en el mercado mundial. Debía hacerse con una menor intervención del Estado, que básicamente estaba dedicado a las labores de privatización de las infraestructuras. Los sectores más afectados fueron los altos hornos, que en parte fueron desmantelados, reconvirtiéndose la zona a otro tipo de actividades, normalmente asociadas a los servicios de bajo valor añadido, como los vinculados al turismo, y a los nichos laborales de la nueva economía del conocimiento. La industria del textil y el cuero deben redefinirse y dedicarse más al diseño que a la producción en masa. Las industrias automotrices se robotizaron, expulsando del sector a mucha mano de obra. Este proceso era en buena parte capitaneado por las compañías multinacionales o extranjeras, y se hizo con apoyo de dinero público, en forma de ayudas fiscales y de jubilaciones anticipadas. Finalmente, la banca pública se privatizó y se produjeron procesos masivos de concentración bancaria. La ley sobre las televisiones privadas entró en la rampa de salida.

Las políticas neoliberales de los gobiernos del PSOE se ocuparon del saneamiento de empresas, al objeto de adecuarlas para su venta al capital privado. En la década de los ochenta la sociedad contempló, algunas veces con estupor, la destrucción del tradicional tejido productivo y el ascenso de los capitales especulativos de origen nacional o internacional. España iba a ser especializada en el sector servicios, de manera específica en el subsector turístico. También fue la época de los grandes proyectos especulativos, plasmados con las inversiones urbanísticas para la Expo de Sevilla y las Olimpiadas de Barcelona de 1992. Entre 1982 y 1996 los gobiernos socialistas privatizaron 80 empresas públicas, de las cuales ingresó 13.000 millones de euros, pero dejó al Estado menguado de sectores estratégicos. Los posteriores gobiernos del PP siguieron la misma senda privatizadora.

En España, no obstante, esta introducción del neoliberalismo se tuvo que hacer con la mejora de los derechos básicos para la población. El estatuto de los trabajadores aprobado en 1980, el acceso a la sanidad y la educación gratuita y universal, así como políticas de protección contra el desempleo y otras mejoras sociales, se inauguraban en España con la democracia, y el caso era diferente al europeo, donde existían amplios derechos sociales desde la época de posguerra que fueron recortados con el inicio de la década. En España esto no podía ser tan lineal, porque sencillamente esos beneficios sociales habían comenzado a disfrutarse de manera incompleta en 1980.

Las políticas socialistas neoliberales fueron contestadas por los todavía relativamente potentes (comparado con la actualidad) sindicatos de clase. E1 PSOE tuvo en sus primeros años el sostén de la UGT, pero hacia 1988 las relaciones estaban muy tensas. En diciembre de ese año UGT y CG. OO. convocaron una exitosa huelga general que consumaba la ruptura entre el sindicalismo de clase 
histórico y el Partido Socialista. A las tensiones que se habían ido produciendo en los años anteriores, el PSOE añadió una razón más cuando impulsó la ley de contratos para jóvenes, que fue denominada como basura (contratos basura). Frente a esa ley, Nicolás Redondo, secretario general de la UGT, manifestó: «Estamos ante lo nunca visto: pagar a empresarios para que contraten trabajadores» ${ }^{8}$.

La huelga, que se celebró el 14 de diciembre de 1988, había logrado concitar un respaldo del $85 \%$ de los asalariados y vino a significar el fin de la tolerancia sindical con las políticas regresivas del Gobierno. El plan gubernamental que parecía concretarse en cada negociación parcial conllevaba una reducción del poder adquisitivo de los salarios, aumentaba la flexibilización del mercado laboral (contratos basura y plan de empleo juvenil) y continuaba privatizando la gestión del empleo público. El intento de imposición unilateral por parte gubernamental del Plan de Empleo Juvenil fue el detonante de la huelga ${ }^{9}$. «El 14D fue una movilización política y no solamente sindical, en la que se expresó el descontento con la política general del PSOE, la revancha por la pérdida del referéndum sobre la OTAN, el malestar por lo que parecía ser una corrupción creciente. Pero el factor decisivo fue de naturaleza política: la iniciativa de los sindicatos de llamar a la movilización» ${ }^{10}$. La huelga significó el último gran triunfo parcial del movimiento obrero de tipo clásico en la historia de España. Desde entonces, el fortalecimiento del neoliberalismo ha ido empequeñeciendo a los sindicatos, sustrayéndoles sus bases y dejándolos sin iniciativa.

Para el Partido Socialista la opción liberal era la única posible. Los miedos de la derecha económica fueron disipados con prontitud tras la llegada del PSOE al poder. Si aquellos estimaban que el ascenso de los socialistas era un peligro para el mantenimiento de sus posiciones de privilegios, pronto quedó claro que no iba a ser así. La apuesta del socialismo por las políticas neoliberales despejó todo tipo de duda en ese aspecto.

El PSOE defendió con tesón la idea ampliamente difundida por el pensamiento neoliberal, desde décadas anteriores (Friedman, Hayek), de que el capital privado era más eficiente que el capital público, y que la forma de gestión de los capitalistas privados genera más rentabilidad que la gestionada por los gestores públicos. Obviamente, esto no deja de ser parte de un discurso ideológico que, sin embargo, fue promocionado en España por quienes en teoría debían ser sus detractores. La absoluta liberalización de la economía

${ }^{8}$ Muniesa, Bernat, Dictadura y Transición II. La monarquía parlamentaria, UB, Barcelona, 2005, p. 215.

${ }^{9}$ Albarracín, Jesús, «La política de los sindicatos y la dinámica del movimiento obrero", en EtXeZarreta, Miren (coord.), La reestructuración del capitalismo en España 19701990, Icaria-Fuhem, Barcelona, 1991, pp. 401-425.

10 Ibíd., p. 423. 
y su inserción en el conjunto de la economía mundial de corte neoliberal fue un objetivo plenamente socialista. Entre las razones que se daban para ello estuvo la necesidad urgente de insertar a España en la CEE, aunque el interés trascendía esa razón, que de por sí era ya muy de peso. El PSOE asumió como reto estratégico esta cuestión ${ }^{11}$.

\subsection{Transición China AL NEOLIBERALISMO}

China se incorpora a la nueva moda neoliberal desde comienzo de los ochenta, dejando atrás el socialismo de Estado, que económicamente había perdido la guerra frente al capitalismo neoliberal. Pero China, influenciada por lo ocurrido en la URSS, decidió llevar adelante las reformas económicas sin que el PCCH perdiese el control y monopolio del poder político.

Desde mitad del siglo xix, tras las guerras del opio y la toma de conciencia de que su antiguo esplendor imperial había quedado sometido al poderío de las potencias occidentales, China trató de buscar sus propias vías modernizadoras, que le permitiesen volver a su grandeza, pero que a la vez la aupasen al ciclo de los avances tecnológicos y económicos con los que los países occidentales habían triunfado.

China buscaba modernizarse para dejar a un lado su atraso interior y para zafarse del dominio occidental. En la transición del siglo xix al xx ensayó la vía revolucionaria del nacionalismo, para a partir de eso construir un Estado centralizado y eficiente, aunque tal vía estaba en tensión permanente con las tradiciones confucianas, budistas y taoístas. Frente a ellas, la juventud nacionalista y revolucionaria oponía la fortaleza del pensamiento científico y el modelo de la democracia liberal. La tensión entre la vuelta a la vieja autocracia o la apuesta por la democracia separó a una generación de jóvenes asiáticos (el fenómeno fue similar en otros países de la zona además de China) de los pensadores de la tradición. Las universidades establecidas en los centros urbanos permitieron una difusión rápida de todas estas nuevas teorías y facilitaron que los jóvenes en edad formativa recorrieran intelectualmente y, más tarde, físicamente el mundo occidental, para a partir de él elaborar la propuesta de construcción de sus nuevas instituciones. Gandhi a Londres, Lu Xun a Japón, Sun Yat-sen a Honolulu. Allí pensaron y elaboraron su pensamiento nacionalista. «A comienzos de siglo xx fue creciendo rápidamente una red intelectual transnacional que puso a dialogar entre sí a los intelectuales asiáticos [...]. En 1901, resultaba algo totalmente

11 Etxezarreta, La reestructuración... 
natural que Kang Youwei escribiera sobre la urgencia de las reformas en China desde la estación de montaña de Darjeeling, en la India» ${ }^{12}$.

Todo ello fue el caldo de cultivo para que en 1911 se produjese una primera revolución en China, que llevó al poder, efímeramente, a Sun Yat-sen, quien proclamó la República y la derrota de la dinastía manchú. Enseguida brotaron los partidos políticos y los medios de comunicación. Después de esta revolución, y tras las elecciones que llevaron al poder al Kuomintang (Partido Nacionalista Chino), hubo un golpe de Estado que obligó a exiliarse a Sun Yat-sen. El golpe del caudillo Yuan pretendía recuperar el confucianismo. Cuando este murió en 1916, su obra se vino abajo y el país se dividió en feudos territoriales, sin que ninguna autoridad central tomara el control. Esto facilitó enormemente que los japoneses, que eran la potencia capitalista más avanzada en Asia, pudiesen invadir China y controlar el país tras la invasión de Manchuria en 1931.

Para ese entonces, además del Kuomintang, existía el Partido Comunista de China, que, obviamente, también tenía como proyecto político la modernización y centralización de China. Con los nacionalistas mantuvieron un frente unido de lucha contra los señores feudales del norte y contra los japoneses. Los comunistas chinos eran especialmente fuertes en las grandes ciudades del país, y tras una larga guerra civil, que duró desde 1927 hasta 1949, y bajo la dirección de Mao Tse-Tung, apoyado en la guerra popular campesina, se hicieron con el poder tras expulsar a los nacionalistas chinos y a su jefe Chiang Kai-shek a la isla de Formosa-Taiwán.

La revolución comunista en China abrió una nueva etapa en el país. Apoyada por la URSS en las primeras décadas, fue consolidando un proceso urbano y modernizador constante, aunque no sin grandes contratiempos y errores de calibre notorio, como fue el fracaso del gran salto adelante (1958-1961), que pretendía, tras un gran proceso de colectivizaciones en el campo, impulsar el rápido desarrollo industrial. Algo parecido a lo que había realizado la URSS en la década de los treinta, también con costos humanos enormes. Después vino la revolución cultural proletaria (1966-1976), que trató de ser una revolución dentro de la revolución, para apartar del poder a los burócratas del partido y del Estado, porque se consideraba que se habían convertido en una clase que obstaculizaba el desarrollo de la revolución hacia el comunismo. Este fue un periodo de mucha violencia y represión, que terminó agotándose sin claros resultados. Con la muerte de Mao se cerró esa experiencia, de la que él era el principal impulsor.

Los dirigentes del partido que habían sido apartados durante la revolución cultural retornaron al poder de manera progresiva a medida que fueron siendo readmitidos e incorporados a cargos de responsabilidad. Den Xiaoping simboliza

12 Mishra, Pankaj, De las ruinas de los imperios. La rebelión contra Occidente y la metamorfosis de Asia, Galaxia Gutenberg, Barcelona, 2014, p. 259. 
este episodio. Purgado durante la revolución cultural, se encarama a la Secretaría General en 1978 y ostenta la autoridad efectiva suprema hasta 1989, aunque tras su retirada sigue ejerciendo de hecho como el líder supremo de la revolución hasta su muerte en 1997.

Su sucesor en el poder llevó adelante los planes de Den, en el sentido de liberalizar la economía. Primero se establecieron zonas controladas. Las reformas fueron liberalizando a amplios sectores económicos del control estatal. Tras las zonas especiales, en las que se permitió la instalación de industrias con capital y gestión privada extranjera, se liberalizaron zonas de la economía agrícola, que entraron a funcionar bajo las reglas del mercado, a excepción de algunos productos, que se mantuvieron bajo control público (algodón). Las zonas de experimentación fueron ampliando su radio de acción en cuanto a los territorios que abarcaban, y también a los sectores económicos implicados. «El surgimiento de empresas municipales y comunales, empresas privadas industriales y comerciales, empresas conjuntas y empresas de propiedad exclusivamente extranjeras, se produjeron fuera de la economía planificada. Juntas formaron un sector económico que sólo respondía a las fuerzas del mercado» ${ }^{13}$.

Las reformas comenzaron bajo la dirección de Den y fueron ampliadas por el primer ministro Zhao Ziyang, que había llevado a cabo un plan sistemático de cambios económicos. Luego sería Jiang Zemin quien promocionase formalmente en el seno del partido el reconocimiento de los nuevos actores emergentes, como eran los empresarios, los intelectuales y los científicos. El reconocimiento formal de estos sectores se entendió como una socialdemocratización del $\mathrm{PCCH}^{14}$. China había entrado con pie firme en la economía capitalista de signo neoliberal, seguía siendo el lugar preferido para la deslocalización de las industrias de Occidente y comenzaba a experimentar tasas de crecimiento de alrededor de un $10 \%$ anual, lo cual la hacía, a su vez, un destino privilegiado para los capitales del mundo que quisieran altas tasas de rentabilidad y mano de obra abundante y barata. En China se instalaron las nuevas plantas industriales para todo tipo de actividad fabril, desde los productos de muy bajo valor añadido a otros de gran valor añadido y alto componente tecnológico. Las empresas norteamericanas primero, y luego las del resto de países industriales, se fueron a China buscando maximizar beneficios, pero ello debilitaba a los propios países de los cuales procedían esos capitales.

El camino de China hacia el neoliberalismo fue una opción elegida por los propios chinos y favorecida por las tendencias estructurales del capital en su búsqueda de óptimas condiciones de rentabilidad. Todo seguía estando, no obstante, bajo el control político e ideológico del PCCH, que tenía que ir renovando y adaptando sus discursos a los nuevos tiempos, de cara a sus millones de

13 ZIYAn, Prisionero..., p. 202.

14 Ríos, China... 
afiliados y a la población en general. «Mao aportó su doctrinario izquierdista. Den Xiaoping lo revolucionó asegurando que el mercado no era incompatible con el socialismo, Jiang Zemin dice que los empresarios no son incompatibles con el PCCH [...]. Hu Jintao [actualizó] su discurso de signo confuciano en el marco de una estrategia de corte nacionalista» ${ }^{15}$.

En la década 2000-2010, China se ha convertido en el principal país captador de capitales extranjeros y en uno de los principales exportadores de capital hacia terceros países. La economía china se terminó de internacionalizar, convirtiéndose en la segunda economía del planeta, detrás de la de EE. UU. y compitiendo con esta por el primer lugar. Desde su admisión como miembro de la Organización Mundial del Comercio (2001), China ha firmado numerosos tratados de libre comercio de manera bilateral y se ha convertido en una defensora firme del libre mercado a nivel planetario. El gigante asiático ha combinado un sistema radical de libre mercado, en donde han emergido empresarios milmillonarios como en ningún otro país, con el mantenimiento del sistema de partido único y el monopolio político del PCCH.

En esta segunda década del siglo xxi, China está impulsando lo que se ha denominado la nueva ruta de la seda, que consiste en unir China con la UE atravesando el Cáucaso, Rusia y Oriente Medio por ferrocarril, y por vía marítima, bordeando el continente asiático y la península arábiga y adentrándose en el Mediterráneo. Esta nueva ruta de la seda unificaría a la gran mayoría de la población mundial, englobaría las zonas más ricas en recursos energéticos y sería la espina dorsal de un gigantesco comercio mundial que deja a EE.UU., como zona periférica, alejado por las barreras oceánicas (Atlántico y Pacífico). De esta forma, China está decidida a jugar un rol de primer orden por el control de la hegemonía mundial.

15 Ibíd. pp. 13-15. 

9. LOS MOVIMIENTOS SOCIALES ALTERGLOBALIZADORES 



\subsection{LAS INSTITUCIONES NEOLIBERALES MUNDIALES}

Con el final de la guerra fría y la desaparición o mengua de las alternativas al capitalismo, tales como el socialismo clásico y sus organizaciones internacionales, y sobre todo con la desaparición de una alternativa global, teórica y política al capitalismo, parecía que se hacía realidad la frase de Thatcher «There Is Not Alternative» (TINA), que venía apuntalada por los trabajos del ideólogo norteamericano Fukuyama cuando hablaba del final de la historia.

Las instituciones del capitalismo global neoliberal estaban firmemente seguras de que su modelo tenía un largo futuro. Sus artefactos institucionales lo conformaban organismos de ámbito económico, político y militar, y frente a ellos no había nada que se opusiera. Tales instituciones eran, en el ámbito económico, el FMI y el BM, ambos nacidos en Bretton Woods en los prolegómenos del final de la Segunda Guerra Mundial; la OCDE (Organización para la Cooperación y Desarrollo Económicos), creada en 1961 y cuyo carácter era de organización intergubernamental, en la que se reunieron los países altamente industrializados de economía capitalista; y el GATT (Acuerdo General sobre Aranceles Aduaneros y Comercio) o Ronda de Uruguay, que se creó en 1947 bajo auspicio de la ONU al objeto de regular el comercio mundial. Primeramente firmado por 23 países, el GATT era un organismo multilateral para el desarrollo de las relaciones comerciales entre países. En 1995 fue sustituido por la Organización Mundial del Comercio (OMC), que se había convertido en el organismo internacional regulador del comercio mundial. Se amplió la organización de manera paulatina a todos los países del mundo, y pertenecer a tal organismo significa aceptar sus normas y principios.

En cuanto a los organismos de naturaleza política que representan la gobernanza global, destaca la ONU (1945), además del Consejo de Europa, que fue creado en 1949 en Londres y tenía como misión servir para avanzar en la cooperación jurídica y política entre los países europeos. Es una organización extracomunitaria a la que pertenecen 47 países del continente y otros miembros observadores, entre los que se encuentran los EE. UU. La organización abarca desde Rusia hasta la península ibérica. Además, la Unión Europea y los EE. UU. son dos instancias potentes que hay que reconocer como miembros de mucho 
peso de las instancias políticas de la globalización. Hasta la crisis de 2008, otro organismo importante fue el G-7+1, que eran los siete países capitalistas más industrializados del mundo (Alemania, Canadá, Estados Unidos, Francia, Italia, Japón y Reino Unido), a los que se sumó Rusia en 1998. Tiene naturaleza informal. Reúne a los jefes de Gobierno de los países y, aunque no tiene un poder real, fue de facto una organización con una potente voz en el escenario internacional. Tras la crisis financiera de 2008, el club se amplió al grupo de los 20 países más importantes del globo. Desde entonces se reúne el G-20, en el que participan, además de los miembros del G-8, los nuevos países industrializados y de peso internacional, tales como China, Brasil, Australia, Argentina, México y otros más. El grupo surgió originariamente en 1999 para coordinar reuniones de los directores de los bancos centrales y ministros de finanzas de los países implicados, pero posteriormente, tras 2009, acuden los jefes de Estado.

En el plano de las organizaciones militares hay que destacar por encima de todas al ejército de los EE. UU. y después, pero muy vinculada, a la OTAN. Los ejércitos de los demás países aliados son extremadamente deudores del norteamericano, de tal forma que pueden ser considerados como peones de este.

Tras la caída de la URSS y del bloque oriental en 1989-1991, las referencias a otro orden de cosas quedaron huérfanas. El presidente norteamericano Bush (padre) proclamó en 1991 el nacimiento del nuevo orden mundial, que ahora era unipolar. Una sola potencia dominaba el mundo. Se inauguró — con un despliegue tecnológico espectacular- con la guerra del Golfo de 1991. En dicha década se produjeron además las guerras de desmembración de la República de Yugoslavia $^{1}$, en las que los norteamericanos jugaron un papel central, tanto en su decantamiento como en la finalización del conflicto en Kosovo ante la impotencia de la UE, que no fue capaz de imponer sus criterios en una guerra que se estaba produciendo en Europa.

\subsection{El movimiento alterglobalizador: de Chiapas a Seattle}

Iba a ser en México, país de la periferia capitalista, donde emergiese nuevamente un movimiento de protesta contra el modelo neoliberal. El 1 de enero de 1994 se alzó en la selva Lacandona de Chiapas, sur de México, el Ejército Zapatista de Liberación Nacional, que vino a ser una suerte de ejército guerrillero, más bien desarmado, con una proyección mediática importante. El EZLN representaba a los movimientos indígenas de México y denunciaba el ostracismo en que estaban sumidas las poblaciones indígenas desde épocas remotas, un estado de marginación y explotación que no encontraba remedio en el Estado-

${ }^{1}$ Veiga, Francisco, La trampa balcánica, Grijalbo, Barcelona, 2002. 
nación mexicano. Los zapatistas se habían alzado contra la firma del Tratado del Área de Libre Comercio de las Américas (ALCA), que entraba en vigor ese día y que creaba un área de libre comercio entre Canadá, EE. UU. y México. El acuerdo era entendido como una agresión a los intereses de los indígenas y de los trabajadores mexicanos, porque iba a poner al país, sus recursos y población, al servicio de los intereses de las empresas norteamericanas.

Además de este hecho concreto, los zapatistas, merced a los medios de comunicación globales, se hicieron notar en el mundo, levantándose cuando por otro lado se hablaba del TINA y del final de la historia. La puesta en escena zapatista, todos con pasamontañas en las ruedas de prensa, y sus denominaciones de «subcomandante» a los dirigentes, venían a simbolizar otra forma nueva de guerrilla, que ahora no quería conquistar el poder, sino señalar sus deficiencias, y reclamar democracia, justicia y libertad, con el cumplimiento de las leyes del Estado. Más que a subvertir el orden legal, los zapatistas llegaron para exigir que se cumpliesen las leyes con las que el propio Estado se había dotado.

El EZLN organizó, en abril de 1996, un primer Encuentro Continental contra el Neoliberalismo y por la Humanidad que tuvo una gran acogida en su país y extendió la solidaridad con los zapatistas por todo el globo. Personalidades e intelectuales de primera fila asistieron en calidad de ponentes y de solidarios. Desde Europa, América, África, asistieron los movimientos sociales, investigadores sociales, escritores y trabajadores para colaborar en la construcción de una alternativa global al neoliberalismo.

En la carta dirigida a los pueblos del mundo, el subcomandante insurgente Marcos, en nombre de toda la dirigencia del EZLN y de los indígenas chiapanecos, expuso algunas de las ideas fuerza de este movimiento. El manifiesto comenzaba diciendo: «Durante los últimos años el poder del dinero ha presentado una nueva máscara encima de su rostro criminal. Por encima de fronteras, sin importar razas o colores, el Poder del dinero humilla dignidades, insulta honestidades y asesina esperanzas. Renombrado como 'Neoliberalismo', el crimen histórico de la concentración de privilegios, riquezas e impunidades, democratiza la miseria y la desesperanza». Para los zapatistas, la globalización neoliberal era una nueva guerra mundial contra las multitudes diversas, a las que excluye del reparto de las riquezas y amenaza con la represión. Las muchas minorías que conforman la mayoría quedan excluidas del nuevo orden. «Indígenas, jóvenes, mujeres, homosexuales, lesbianas, gentes de colores, inmigrantes, obreros, campesinos; las mayorías que forman los sótanos mundiales se presentan, para el poder, como minorías prescindibles». Se quiere que el encuentro sirva para dar visibilidad y organización a todos esos nuevos sujetos. Aquí ya no se habla solo de movimiento obrero, ni de campesinos, que son los viejos sujetos de las sublevaciones históricas, sino que se remarca la existencia de multitudes de sujetos para el cambio social y político.

Los zapatistas abren así un nuevo ciclo de luchas y de resistencias a la hegemonía del capital, que tomará más adelante nuevo impulso. El balance final que 
se hizo del encuentro fue positivo y conminó a los asistentes a la preparación de otro nuevo, en el que se incorporasen más organizaciones y nuevas problemáticas. En su conclusión quedaron recogidas estas ideas: «Lo mismo en Canadá, Estados Unidos de América, México, Guatemala, Costa Rica, Venezuela, Puerto Rico, Ecuador, Brasil, Perú, Chile y Argentina, hemos encontrado lo que nos hace iguales: un enemigo, el neoliberalismo, y una causa, la de la humanidad. Esperamos que en el próximo encuentro asistan representantes de los otros países de América. Pero esta reunión preparatoria ha sido también eso, una preparación para algo que ya empieza a inquietar a los continentes europeo, asiático y oceánico. Una preparación que preocupa al Poder mundial y que le provoca un miedo que le recorre la columna vertebral de oro y mierda que lo sostiene. El Poder tratará de evitar otros encuentros como el de La Realidad. Y nosotros debemos defender este sueño, traerlo bien guardado en el bolsillo del pantalón y sacarlo cada tanto para una caricia o para un aliento ${ }^{2}$.

Después del impulso zapatista se dio un nuevo salto en el movimiento alterglobalizador, o antiglobalización, en Seattle con una gran manifestación y un campamento urbano en el que participaron decenas de miles de activistas antiglobalización. En la cumbre se pretendía abrir lo que se denominó la Ronda del Milenio, y la propuesta consistía en ampliar la liberalización y desregulación del comercio mundial y aplicar sus efectos a todo tipo de productos y saberes. «La cumbre de Seattle había sido preparada minuciosamente por los principales centros de poder político, en íntima interrelación con el poder económico y financiero transnacional, que había definido la agenda de la cumbre. Se habían establecido mecanismos de cooptación (creación de mesas de 'diálogo' con los principales sindicatos y ONGs), para lograr simular la participación de la denominada 'sociedad civil' en los preparativos de la misma, de cara a legitimar sus resultados. Las principales transnacionales y grandes grupos financieros (Microsoft, Boeing, Chase Manhatan, Bank of America, IBM, etc.) se habían hecho cargo de los costes de organización del encuentro, actuando como patrocinadores de la cumbre. Y se había invertido un considerable esfuerzo mediático e institucional para resaltar los enormes beneficios que se iban a derivar para las sociedades del mundo entero a través de la Ronda del Milenio, una profunda liberalización adicional sobre la ya conseguida en la Ronda Uruguay» ${ }^{3}$. La cumbre fue paralizada por la acción conjunta de multitud de organizaciones sociales, desde agricultores a ecologistas, de intelectuales a activistas sindicales, gente común, pequeños productores, profesionales, asalariados de distintos sectores. Se puso de manifiesto la existencia de ese sujeto múltiple, diverso, que tenía voluntad de actuar ante las

${ }^{2}$ Http://palabra.ezln.org.mx/comunicados/1996/1996_04_07.htm (visitado 25/1/2016).

\footnotetext{
${ }^{3}$ Http://habitat.aq.upm.es/boletin/n15/arfer_4.html (visitado 25/1/2016).
} 
disposiciones, consideradas injustas, de las grandes corporaciones. En la ciudad se tuvo que declarar un toque de queda, y la intervención contundente de los aparatos represivos violentó con dureza a los manifestantes. No obstante, la cumbre se suspendió y tuvieron que dejar para más adelante la agenda de trabajo. Esa fue la primera vez que el rechazo a la OMC saltó a la televisión y a las primeras planas de la prensa mundial. Los activistas caracterizaban al organismo como antidemocrático, injusto, opaco y desequilibrado; esto último hacía referencia al gran poder que tenían las corporaciones nacionales en su seno y las grandes potencias, en detrimento de las menos desarrolladas.

Así que Seattle inauguró una nueva forma de protesta en la era global. De ahí en adelante los activistas antiglobalización irán a protestar y tratar de boicotear las cumbres o reuniones de los gobiernos e instancias del capitalismo global, bien se tratase del FMI, el BM, el G-8, la OMC o grupos interministeriales de trabajo. Los activistas se organizaron a lo largo del mundo, y en cada continente, país o ciudad surgieron grupos de trabajo para preparar las contracumbres en cada caso, así como elaborar propuestas alternativas de otra forma de globalización, que respetara el medio ambiente, las culturas diversas, las minorías nacionales y todo grupo que se sintiese dañado por la forma de funcionamiento de la globalización neoliberal. La siguiente gran protesta tuvo lugar en Washington en la reunión que mantuvieron el BM y el FMI en abril de 2000. En septiembre ocurrió lo mismo en Praga contra la reunión del BM.

La nueva forma de organización surgida no se asienta sobre partidos políticos o sindicatos, como era el caso con las organizaciones internacionalistas del movimiento obrero, sino que ahora la multitud de sujetos individuales y colectivos que participan en esas nuevas dinámicas sociales lo hacen de manera sectorial. Cada sector, organización, movimiento, tiene sus propias preocupaciones y proyectos, ninguno habla en nombre de todos, sino que la sociedad civil, por medio de sus organizaciones plurales, produce novedosas formas de articulación colectiva, que deben ser, eso sí, gestionadas de abajo hacia arriba y promoviendo conductas de democracia horizontal. El movimiento social no aborda la cuestión del poder político, sino que se centra en la denuncia de los elementos de descomposición social que ha traído el neoliberalismo globalizado a las sociedades mundiales ${ }^{4}$. Los movimientos de contracumbre han primado la crítica y la protesta contra las injusticias. Paralelamente ayudan a crear conciencia de grupo, alimentando sinergias en muchas escalas sociales y territoriales, e identidades transnacionales y posnacionales.

${ }^{4}$ Usatehui Uriarte, Ricardo, «Análisis del nacimiento y desarrollo del movimiento antiglobalización», en Intersticios, vol. 3, 2009. Http://www.intersticios.es. 


\subsection{El Foro Social Mundial}

Después de las concentraciones y manifestaciones contracumbre, el movimiento se desplazó a un nuevo epicentro de referencia. La ciudad de Porto Alegre, capital del estado de Río Grande del Sur, en Brasil, acogería desde enero de 2001 la celebración del i Foro Social Mundial. Ahora no se trataba de una contracumbre al paso de las cumbres de los poderes mundiales, sino de la creación de un espacio para el debate, encuentro, elaboración de ideas y programas de todos aquellos movimientos sociales mundiales que quisieran oponerse al neoliberalismo global. Se eligió la fecha de principios de enero para hacerla coincidir con la cumbre que anualmente tenían los poderes del mundo en la ciudad suiza de Davos, llamado Foro Económico Mundial, o Foro de Davos.

El Foro de Porto Alegre se celebró de forma consecutiva los siguientes dos años en la misma ciudad, y después se trasladó a Mumbai, Caracas, Nairobi, Belem, Dakar, Túnez y Montreal. La estructura organizativa del Foro se replicó en escalas menores, celebrándose foros continentales (Europa, América, Oceanía, África, Asia), y luego por países, regiones y ciudades, pero siempre manteniendo la misma filosofía. Estructura horizontal, trabajo por áreas temáticas o por problemas de grupo, en los que nadie podrá hablar en nombre del conjunto del Foro, sino solo de la organización social o política a la que pertenece. De esta manera se trataba de impedir que nadie pudiese hacer un uso interesado de los foros sociales.

La estructura organizativa del Foro, su forma de funcionamiento, así como sus objetivos, se recogieron desde la primera cumbre en una carta de principios que todo participante debería acatar. En ella se decía que era un espacio abierto para el encuentro, la reflexión y el intercambio de experiencias al objeto de buscar vías alternativas al neoliberalismo, y que en su perspectiva de lucha contra el imperialismo abogaba por una relación ecológica y sostenible de las actividades humanas en la escala planetaria. Defendían una globalización solidaria, que respetase los derechos humanos, las culturas, naciones y soberanía de los pueblos y su diversidad, así como la justicia social. El Foro, que tenía una dimensión planetaria, no quería ser, sin embargo, una «instancia de representación de la sociedad civil mundial» ${ }^{5}$.

El Foro, en su crítica frontal al modelo neoliberal, «se opone a toda visión totalitaria y reduccionista de la economía, del desarrollo y de la historia y al uso de la violencia como medio de control social por parte del Estado. Propugna el respeto a los Derechos Humanos, la práctica de una democracia verdadera y participativa, las relaciones igualitarias, solidarias y pacíficas entre las personas,

Http://www.movimientos.org/es/derechos-comunicacion/show_text.php3\% 3Fkey\%3D6200 (visitado 25/1/2016). 
etnias, géneros y pueblos, condenando a todas las formas de dominación o de sumisión de un ser humano a otro» ${ }^{6}$.

Para sus debates, el Foro funcionó — dado el gran número de participantes en cada ocasión, siempre decenas de miles de personas-de manera descentralizada, normalmente por decenas de espacios habilitados en las ciudades de acogida para la celebración de los múltiples talleres, sesiones de ponencias, encuentros entre organizaciones, espacios para reuniones informales, lugares para el teatro, la música y las manifestaciones de protesta o reivindicación según la agenda de la política internacional en cada caso. Por ejemplo, el Foro de 2003 tuvo una especial atención a las propuestas y protestas contra la inminente declaración de guerra en Irak que iba a llevar a cabo la Administración de Bush (hijo).

Todo ese tipo de encuentros sirvieron para que cada cual se llevase de vuelta a su país, región, nación o ciudad tareas derivadas de lo acordado en las reuniones a las que se asistió, al objeto de seguir profundizando en los trabajos con los que se venían comprometiendo antes de la llegada al Foro, o buscando nuevos espacios de trabajo colectivo aprendidos de experiencias de gentes de otros lugares.

El malestar generado en la ciudadanía global a inicios del siglo xxi estaba acentuado porque se había instalado un sistema que era percibido por mucha gente como injusto y asentado sobre medias verdades difíciles de aceptar. $\mathrm{Si}$ bien las corporaciones y los gobiernos abogaban por el libre comercio, y en su defensa habían organizado las instituciones de gobernanza global, no es menos cierto que tal libertad de comercio estaba trucada, porque en el fondo son las grandes corporaciones multinacionales y los gobiernos más poderosos los que establecen las reglas del juego en esas instancias internacionales. «Los acuerdos internacionales de libre comercio envuelven una intrincada combinación de liberalización y proteccionismo en muchos sectores estratégicos, como en el caso de la industria farmacéutica, permitiendo que megaempresas obtengan ganancias enormes gracias al control monopolístico que ejercen sobre los precios de las medicinas que, por otra parte, se desarrollan con una sustantiva contribución del sector público» ${ }^{7}$.

En Porto Alegre hubo un debate que atravesó las experiencias de los siguientes foros, entre una visión socialdemócrata o nacionalista del proyecto y otra que pretendía romper los marcos tradicionales del Estado-nación. Muchos países latinoamericanos apostaron por la necesidad de fortalecer las estructuras

${ }^{6}$ Ibíd.

7 Monereo, Manuel y Riera, Miguel (editores), Porto Alegre. Otro mundo es posible, Viejo Topo, Madrid, 2001, p. 14 (la cita corresponde a la contribución de Noam Chomsky). Taibo, Carlos, Movimientos antiglobalización: ¿qué son? ¿qué quieren? ¿qué hacen?, La Catarata, Madrid, 2007. 
de los Estados-nación, para de esta forma poder oponerse con fuerza a los capitales transnacionales. Quienes opinaban así pensaban que era prioritario que las fuerzas de izquierda y nacionalistas accediesen al poder en los distintos países del continente. Y, efectivamente, aquello fue lo que comenzó a suceder, cuando en los países del Caribe y del sur, gobiernos nacionalistas y socialdemócratas comenzaron a verificarse (Venezuela, Bolivia, Ecuador, Brasil, Argentina). El otro lado del debate estuvo representado por quienes entendían que había llegado la hora de trascender el Estado-nación, superarlo y llegar a instancias democráticas de alcance más global. Este tipo de pensamiento lo promocionaban activistas y pensadores de procedencia europea y norteamericana. En cualquier caso, el debate se enmarcó en ambos casos bajo el lema que desde entonces identificó a los foros sociales por el mundo. Otro Mundo es Posible. Ese otro mundo era el que promovía el pensamiento alterglobalizador. 


\section{EPÍLOGO}



La historia contemporánea ha sido muy dinámica. Las sociedades mundiales se han visto transformadas en un corto periodo de tiempo. Desde finales del siglo XVIII hasta nuestros días, el mundo pasó de ser un conjunto de pueblos y culturas dispersas a un mundo integrado desde todos los puntos de vista.

La construcción de los Estados nacionales, el desarrollo de la economía capitalista, el trasvase incesante de población de los ámbitos rurales a los urbanos modificó al planeta y a sus habitantes muchísimo más rápido, y con mayor profundidad, que los miles de años precedentes.

En la actualidad no hay apenas desafío que no requiera una respuesta mundial. Consumimos los recursos a gran velocidad, y alteramos los equilibrios ecológicos de manera crítica. Y aunque estas cuestiones requieren la cooperación de todos los gobiernos para solucionarlo, o al menos la de los más importantes, sigue primando, y lo seguirá en el futuro, un punto de vista nacional o regional para abordarlos.

La geopolítica se ha convertido en un elemento central. Los juegos de fuerzas internacionales están retardando la resolución de asuntos muy urgentes, y es bastante probable que se sigan postergando. El mundo neoliberal se encuentra en una delicada situación tras la crisis de 2008. Y si parece que en el centro del sistema el modelo se encuentra agotado, aún tiene margen de maniobra en la periferia. Los países BRICS, sobre todo Rusia, China e India, encaminados por la senda neoliberal, tirarán del modelo durante un largo tiempo.

El mundo globalizado está produciendo un nuevo orden mundial policéntrico. Estados Unidos, China, Rusia y la Union Europea seguirán siendo actores claves en el futuro, y a su vez englobarán bajo sus intereses a otras regiones. Para la UE y para Rusia es vital la estabilidad en Oriente Medio y en el Cáucaso.

Actores no estatales, como son las compañías multinacionales y globales, tendrán un papel creciente, rivalizando con los Estados nacionales menos fuertes por el control de las actividades económicas. Y los organismos supraestatables como la OMC, G-7, G-20, FMI, BM y otros continuarán siendo determinantes para el funcionamiento del orden mundial.

Sin embargo, a día de hoy EE. UU. y China destacan por encima de las demás potencias. China y EE. UU. capitanean las alianzas comerciales en disputa. Los primeros están impulsando lo que se ha denominado la nueva ruta de la seda, que 
consiste en unir China con la UE atravesando el Cáucaso, Rusia y Oriente Medio por ferrocarril, y por vía marítima pretenden bordear el continente asiático, la península arábiga y adentrarse en el Mediterráneo. Esta nueva ruta de la seda unificará a la gran mayoría de la población mundial, englobará las zonas más ricas en recursos energéticos y será la espina dorsal de un gigantesco comercio mundial, que deja a los EE. UU., como zona periférica, alejado de la misma por las barreras oceánicas (Atlántico y Pacífico).

Por su lado, los EE. UU. negocian con la UE y con los países asiáticos acuerdos comerciales transatlánticos. Con los segundos, el denominado Acuerdo Estratégico Trans-Pacífico de Asociación Económica (TPP), y con la UE, el TTIP. Ambos están orientados a la expansión del comercio a través de los dos océanos, en donde los EE. UU. son el pivote central. En los dos acuerdos China queda marginada. Esta sería la ruta de la seda norteamericana, y convertiría a los océanos en autopistas de comunicación, junto con los respectivos espacios aéreos. Estos juegos de fuerzas van a marcar el rumbo del mundo en las próximas décadas.

Confiemos en que las disputas se mantengan en el terreno comercial, y en ningún caso adopten la vía militar. Una guerra global nos llevaría de nuevo al Neolítico o al final de la vida en la Tierra. 
ANEXO I 

Películas Recomendadas ${ }^{1}$

Napoleón (Abel Gance) 1927.

Octubre (Serguéi Eisenstein) 1928.

Novecento (Bernardo Bertolucci) 1976.

Europa (Lars von Trier) 1991.

Buenas noches y buena suerte (George Clooney) 2005.

La batalla de Argel (Gillo Pontecorvo) 1965

Memorias del subdesarollo (Tomás Gutiérrez Alea) 1968.

La chaqueta metálica (Stanley Kubrick) 1987.

Munich (Steven Spielberg) 2005.

Salvador Puich Antich (Manuel Huerga) 2006.

La batalla de Chile (Patricio Guzman) 1975.

El último rey de Escocia (Kevin Macdonald) 2006.

Riff.Raff (Ken Loach) 1990.

Good bey, Lenin (Wolfgang Becker) 2003.

También la lluvia (Icíar Bollaín) 2010.

\section{Novelas RECOMENDADAS}

Alejo Carpentier, El siglo de las luces.

Wu Ming, Manituana.

Louis-Ferdinand Céline, Viaje al fin de la noche.

André Malraux, La condición humana.

Marguerite Duras, El amante.

Antonio Tabucchi, Sostiene Pereira.

Milan Kundera, La broma.

Naguib Mahfouz, El callejón de los milagros.

Alberto Moravia, Los indiferentes.

James Ellroy, América.

Graham Greene, El americano impasible.

Elena Poniatowska, La noche de Tlatelolco.

Manuel Vázquez Montalbán, Quinteto de Buenos Aires.

Svetlana Alexievich, Voces de Chérnobil.

Yevgueni Yevtushenko, No mueras antes de morir.

${ }^{1}$ Esta breve selección de películas y libros solo tiene valor orientativo. 

ANEXO II 

1. Colonización hacia $1945^{1}$

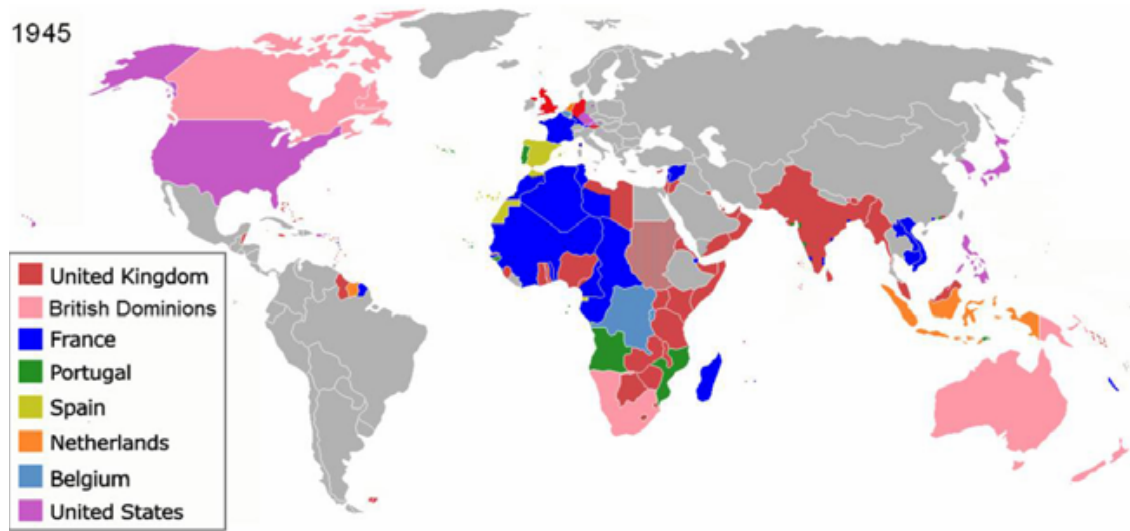

\section{Países de la antigua $\mathrm{URSS}^{2}$}

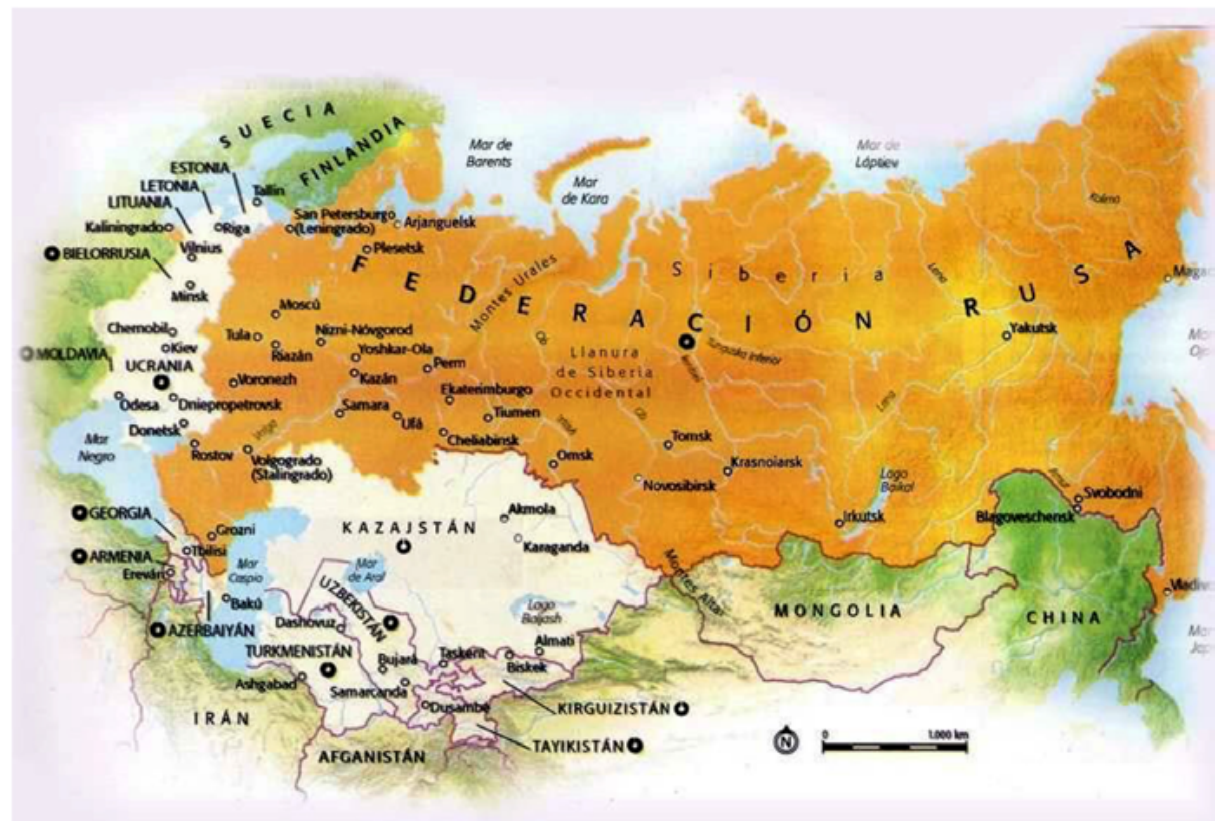

${ }^{1}$ Https://commons.wikimedia.org/wiki/Atlas_of_colonialism.

${ }^{2}$ Http://historiaybiografias.com/archivos_varios3/mapa_urss.jpg. 
3. Acuerdos Sykes-Picot ${ }^{3}$

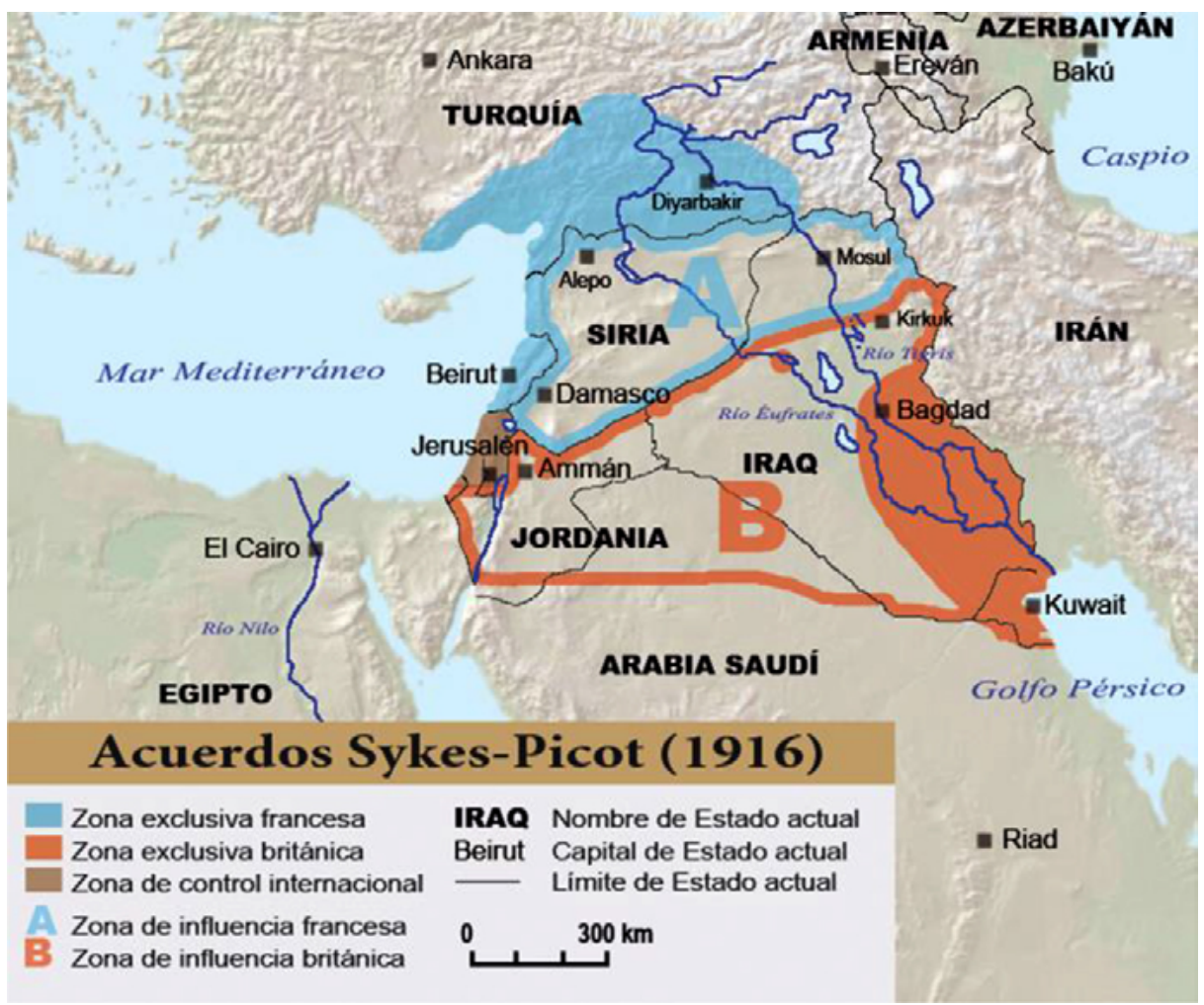

${ }^{3}$ Https://es.wikipedia.org/wiki/Acuerdo_Sykes-Picot\#/media/File:Sykes-picot.png. 
4. Partición británica de la India en $1947^{4}$

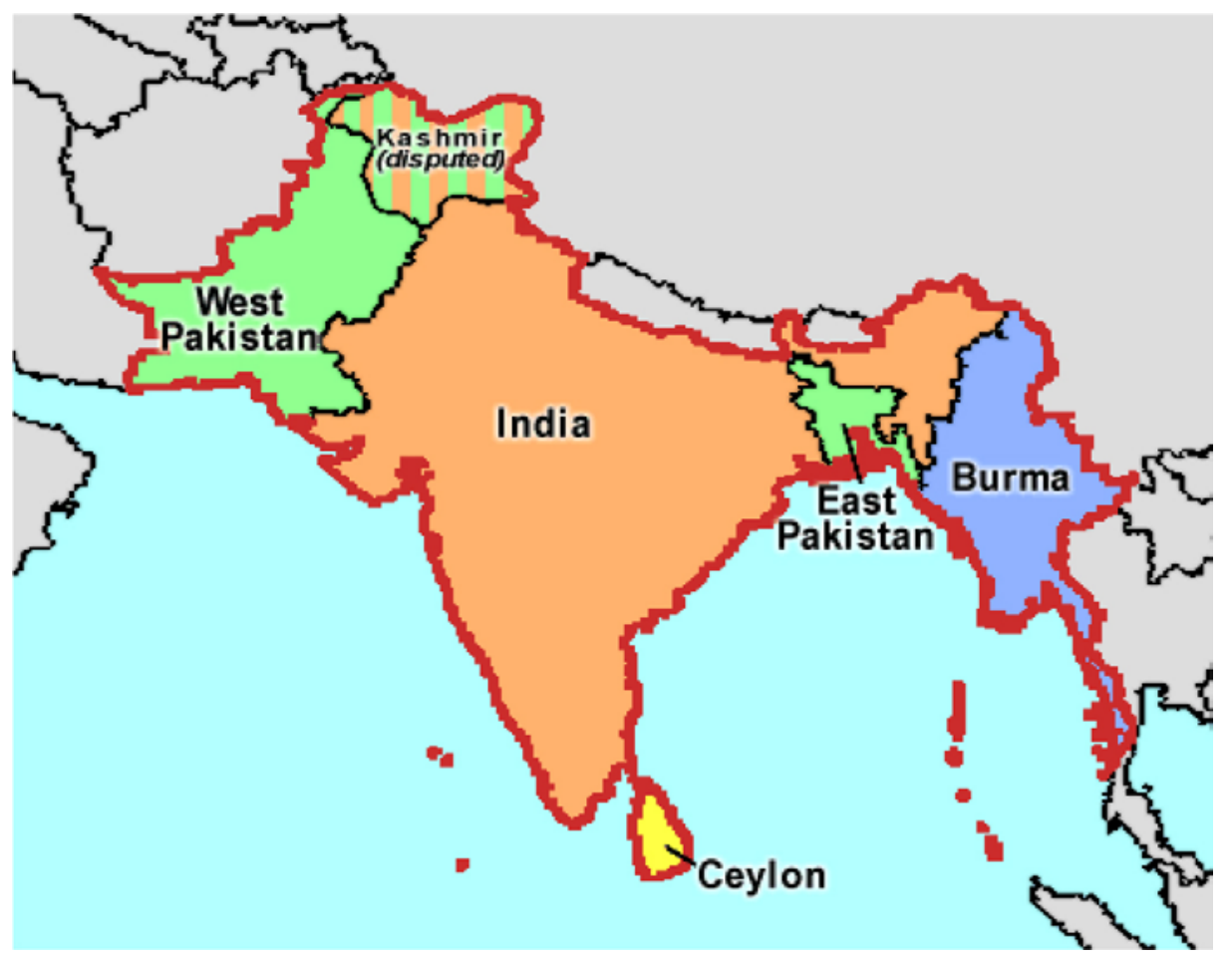

${ }^{4}$ Https://commons.wikimedia.org/wiki/Atlas_of_colonialism. 



Universidad
de La Laguna

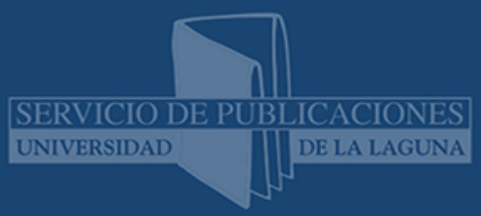

